DP-1513

Distribution Category: UC-13

\title{
EARTHQUAKE DAMAGE TO UNDERGROUND FACILITIES
}

by

H. R. Pratt*

W. A. Hustrulid*

D. E. Stephenson

Approved by

T. V. Crawford, Research Manager Environmental Transport Division

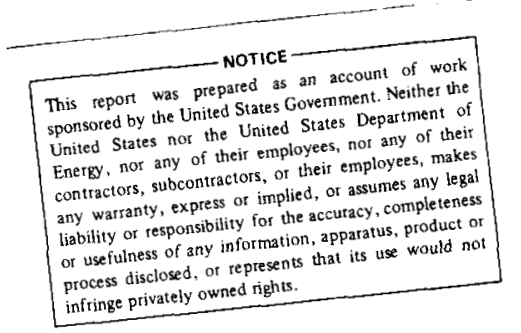

Publication Date: November 1978

\section{E. I. DU PONT DE NEMOURS AND COMPANY SAVANNAH RIVER LABORATORY AIKEN, SOUTH CAROLINA 29801}

PREPARED FOR THE U. S. DEPARTMENT OF ENERGY UNDER CONTRACT AT(07-2)-1

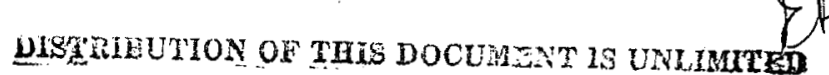

* Terra Tek, University Research Park, 420 Wakara Way, Salt Lake City, Utah 84708 


\section{DISCLAIMER}

This report was prepared as an account of work sponsored by an agency of the United States Government. Neither the United States Government nor any agency Thereof, nor any of their employees, makes any warranty, express or implied, or assumes any legal liability or responsibility for the accuracy, completeness, or usefulness of any information, apparatus, product, or process disclosed, or represents that its use would not infringe privately owned rights. Reference herein to any specific commercial product, process, or service by trade name, trademark, manufacturer, or otherwise does not necessarily constitute or imply its endorsement, recommendation, or favoring by the United States Government or any agency thereof. The views and opinions of authors expressed herein do not necessarily state or reflect those of the United States Government or any agency thereof. 


\section{DISCLAIMER}

Portions of this document may be illegible in electronic image products. Images are produced from the best available original document. 
The potential seismic risk for an underground nuclear waste repository will be one of the considerations in evaluating its ultimate location. However, the risk to subsurface facilities cannot be judged by applying intensity ratings derived from the surface effects of an earthquake. It is common knowledge in mining circles that the damage caused by an earthquake is significantly less in the subsurface than it is at the surface; mines have operated for a substantial period of time in some of the most seismically active regions of the world.

If the smaller damage effects of earthquakes in the subsurface are to be used in assessing the hazard to an underground nuclear waste repository, then a quantitative data base is needed to replace the general precept that earthquake damage is minimal to nonexistent in the subsurface. The purpose of this study was to develop such a quantitative data base.

A literature review and analysis were performed to document the damage and non-damage due to earthquakes to underground facilities. Damage from earthquakes to tunnels, mines, and wells and damage (rock bursts) from mining operations were investigated. Damage from documented nuclear events was also included in the study where applicable.

Principal conclusions developed in this study are:

- There are very few data on damage in the subsurface due to earthquakes. This fact itself attests to the lessened effect of earthquakes in the subsurface because mines exist in areas where strong earthquakes have done extensive surface damage.

- More damage is reported in shallow tunnels near the surface than in deep mines.

- In mines and tunnels, large displacements occur primarily along pre-existing faults and fractures or at the surface entrance to these facilities.

- Data indicate vertical structures such as wells and shafts are less susceptible to damage than surface facilities.

- More analysis is required before seismic criteria can be formulated for the siting of a nuclear waste repository. 
PREFACE

The National Waste Terminal Storage Program was initiated to conduct the research to select a site for the disposal of high-level radioactive waste in deep geologic formations. As part of this program, the Savannah River Laboratory is conducting geologic research that is particularly relevant to potential repository sites in the Southeast and of generic applicability. One generic study in this program is concerned with earthquake damage to a repository in a geologic media. Part of this study was conducted by Terra Tek under contract to the Savannah River Laboratory. This report presents the results of the first phase of the study. 


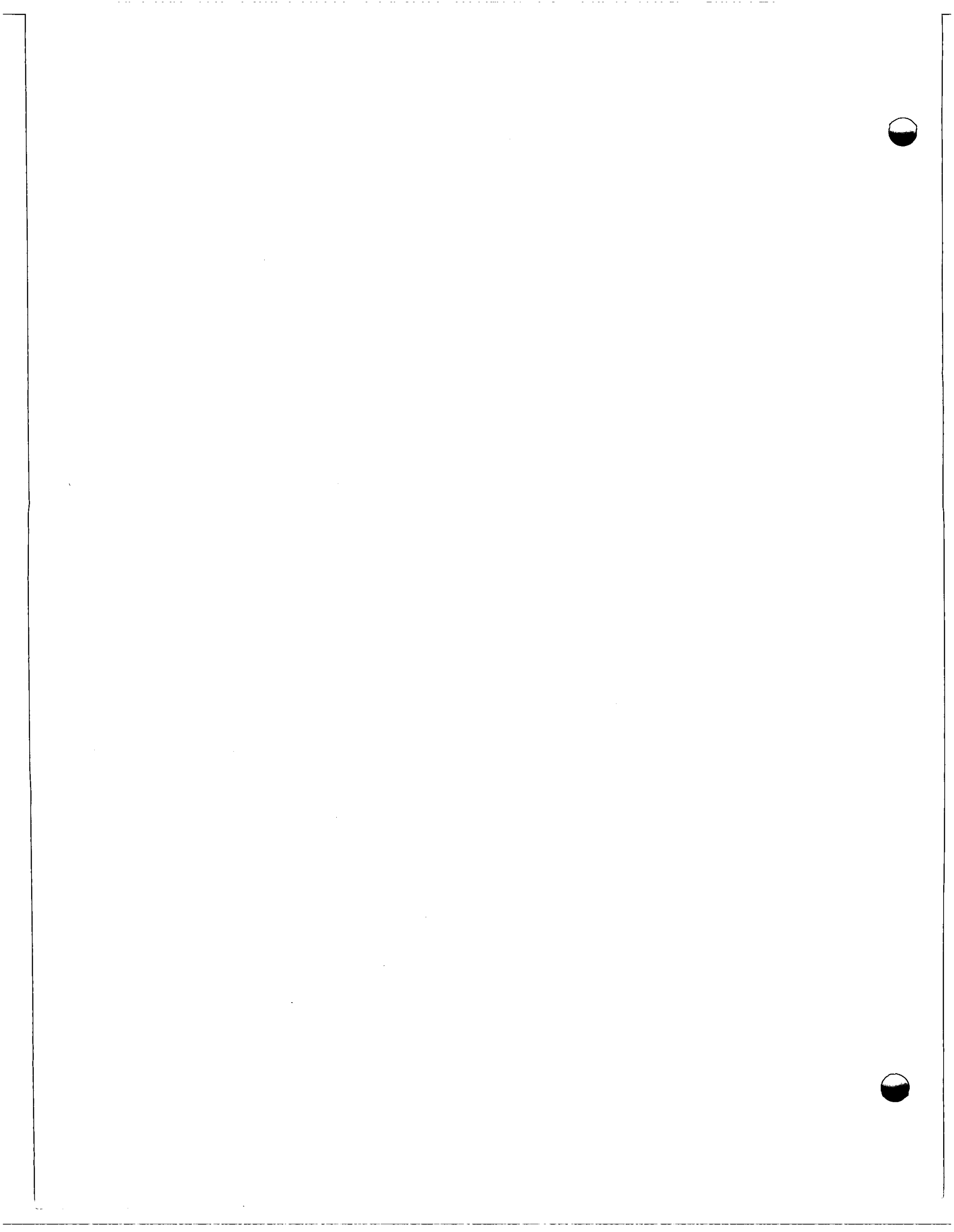




\section{CONTENTS}

Introduction $\quad 9$

Background 10

Existing Data Base on Earthquake Damage 20

Tunnels and Shallow Underground Openings 20

Mines or Other Deep Structures 28

Wells 36

Nuclear Events as Earthquake Simulators 41

Conclusions 60

Appendix A - Earthquake Damage to Tunnels 61

Appendix B - Effects of the March 1964 Earthquake on Wells of the Alaska Area 69

References 73

Special Distribution 79 


\section{LIST OF TABLES}

1 Earthquake Measurements - Modified Mercalli Intensity Scale (1956 Version) 12

2 Maximum Accelerations During 16 Moderate Earthquakes Recorded Around Tokyo Bay, 1970-75 35

3 We11s Damaged by the Alaska Earthquake of March $1964 \quad 40$

4 Data from Nuclear Events 42

5 Nuclear Event Statistics for LONGSHOT, MILROW, and CANNIKIN 49

6 MILROW and CANNIKIN Subsurface Motion Data 49

7 MILROW Surface Motion Data 50 


\section{LIST OF FIGURES}

1 Risk of Damage from Earthquakes in the United States 14

2 Earthquakes (Intensity $\mathrm{V}$ and Above) in the United States Through $1970 \quad 15$

3 Comparison of Site-Independent Spectra 16

4 Surface Acceleration Versus Intensity 17

5 Maximum Probable Ground Velocities 18

6 Predominant Periods for Maximum Acceleration in Rock 19

7 Calculated Peak Acceleration at the Surface and Associated Tunne1 Damage 21

8 Accelerations, Modified Mercalli Intensity, and Associated Tunne1 Damage 22

9 Spread of Attenuation Relationships for a Magnitude 6.5 Earthquake 23

10 Velocity as a Function of Focal Distance for Various Site Conditions 24

11 Various Relationships Between Peak Acceleration and Distance from Source for Magnitude 6.5 Earthquakes 25

12 Acceleration Records Taken on the Surface and $38 \mathrm{~m}$ Underground at Sudagai, Northern Gumma Perfecture, Japan 30

13 Precursor Time for Several Different Failures as a Function of Source Dimension 31

14 Schematic Cross Section of Structural Setting of Earthquake at Welkom, South Africa, December 1976

15 Summary of Damage Levels 37

16 Measured Range of Displacements as a Function of Depth 38

17 Mean Surface-Wave Magnitude (M) Versus Body-Wave Magnitude $(m)$ for 28 Earthquakes and 26 Nuclear Explosions in Southwestern North America, as Determined by Canadian Measurements 42

18 Body-Wave Magnitude Versus Explosion Yield and Rock Type 43

19 A Family of Predicted Mean Pseudo-Relative Response Velocity Curves for Seven Yields with $5 \%$ Damping at a Distance of $100 \mathrm{~km} \quad 45$ 
20 Acceleration as a Function of Period for the 1940 E1 Centro Earthquake and a Buried 1-Mt Nuclear Event

21 Pseudo-Relative Response Velocity Versus Damped Spectral Response 47

22 Spectral Response to Ground Motion at Station SE-G, N/S Component, Las Vegas, Event BOXCAR (L-7) 48

23 Surface Vertical Displacement Attenuation 52

24 MILROW Fault Displacement Hodographs, Rifle Range Fault 53

25 Velocity and Stress as a Function of Scaled Range 54

26 Acceleration as a Function of Scale Range for the GNOME Event 56

27 Average Spectral Response for the Roof and Floor from the Colony Mine 57

28 Velocity and Stress as a Function of Scaled Range 58 


\section{EARTHQUAKE DAMAGE TO UNDERGROUND FACILITIES}

\section{INTRODUCTION}

The potential seismic risk for an underground nuclear waste repository is considered in evaluating the ultimate location of the facility. The possible damage resulting from either largescale displacements or high accelerations should be considered in evaluating a potential site. Current concepts envision a repository sited in one or more of a variety of geologic media at depths ranging from 500 to 1500 meters (m). The geologic media being considered include salt, shale (argillite), and crystalline rock. Independent geologic studies are being conducted to assess the feasibility of siting a repository in these media in the continental United States.

Scattered through the available literature are statements to the effect that below a few hundred meters shaking and damage in mines are less than at the surface; however, data for decreased damage underground have not been completely reported and explained.

In order to assess the seismic risk for an underground repository, a data base must be established and analyzed to evaluate the potential for seismic disturbance. To develop this data base, a search of the literature was made to document the damage or non-damage to underground facilities due to earthquakes and to evaluate the significance of these data. A number of reports listed damage from earthquakes to underground structure such as mines and tunnels, but these were primarily of a qualitative nature. Displacements associated with four major earthquakes in several parts of the world were documented in $1959 .^{1}$ More recently, the effect of earthquakes on shallow tunnels, primarily in the United States, has been collected and analyzed. ${ }^{2}, 3$ In addition to these data, a large number of individual reports have indicated both damage and non-damage resulting from earthquakes of magnitudes greater than 5.4-8

In addition to these data, other sources of potential information were investigated. These include:

- More complete and recent data from foreign sources in earthquake prone areas such as Japan.

- Data from mining operations where earthquakes are initiated by the mining process. (These needed to be evaluated in terms of the potential damage from equivalent far-field earthquakes.) 
- Results from the nuclear events at the Nevada Test Site and the Alaskan Test Site as well as Plowshare experiments. These tests provide the most quantitative data in the nearfield environment. These tests were well instrumented and may assist in evaluating and establishing damage criteria with respect to the seismic spectrum resulting from an earthquake.

Recent technical interchange with the Chinese, Russians, and Japanese has increased our data base significantly with respect to methods for earthquake prediction and the damage resulting from destructive earthquakes. These foreign groups were contacted as well as the United States geologists (Raleigh and Brace) who have made recent trips to these countries. Also the cognizant groups in Asia, Europe, and South America were contacted for pertinent information. It was the aim of the study to gather as large a data base as possible because of the relatively infrequent occurrence of large earthquakes in any one country.

Data on mines and mining operations were collected from government agencies (U. S. Geological Survey, U. S. Bureau of Mines, California Division of Mines and Geology, etc.). Personnel in those agencies were contacted for published data and individual discussion.

Nuclear events provided a quantitative data base for the near-field effects in region of large displacements and high acceleration. Nuclear events like BOXCAR, BENHAM, MILROW, and CANNIKIN were greater than one megaton $(>1 \mathrm{Mt})$, equivalent to a magnitude of $\sim 6.5$ earthquake. ${ }^{9-11}$ Scaled ground motion data from a number of these sources may provide part of the empirical basis to establish a damage criteria for a waste repository.

\section{BACKGROUND}

The focus, or hypocenter, of an earthquake is the source of the waves that form the earthquake. The depth of focus is the depth of the source below the surface.

Earthquakes are classified by depth of focus as follows:

$\begin{array}{lr}\text { Shallow } & 0-70 \mathrm{~km} \\ \text { Intermediate } & 70-300 \mathrm{~km} \\ \text { Deep } & 300-700 \mathrm{~km}\end{array}$


The epicenter is the point on the earth's surface above the focus of the eartinuake.

The magnitude of an earthquake is a measure of ground motion recorded at a seismic station. The term was originally defined by Richter (1935) 12 to facilitate comparison of the amount of energy released in earthquakes. Richter's original work was done with data from shallow earthquakes in southern California and adjoining states.

Richter ${ }^{12}$ defined local magnitude $\left(\mathrm{M}_{\mathrm{L}}\right)$ as the logarithm (base 10) of the largest amplitude measured in microns $(0.001 \mathrm{~mm})$ on the record made by a standard Wood-Anderson torsion seismometer (period $=8.0$ seconds, magnification $=2800$, and damping factor $=$ 0.8 ) at a distance of $100 \mathrm{~km}$ from the epicenter of the earthquake. The magnitude of an earthquake recorded at other distances can be determined if it is known how the largest amplitude varies with distance.

Gutenberg and Richter ${ }^{12,13}$ investigated the relation between the energy released by an earthquake and its magnitude and found that

$$
\log _{10} E=5.8+2.4 m
$$

and since the body-wave magnitude $m=2.5+0.63 \mathrm{M}$, this is equivalent to

$$
\log _{10} E=11.4+1.5 \mathrm{M}
$$

where $E$ = total energy released by an earthquake in ergs, and $M=$ magnitude of an earthquake determined from surface waves.

The intensity of an earthquake is the amount of shaking, damage to property, and earth deformation felt or observed at a given place. Intensity is measured in terms of arbitrarily defined scales. The most widely used intensity scale is the Modified Mercalli (MM) scale shown in Table $1 .^{14}$ Richter $^{15}$ points out that the intensity of an earthquake does not represent a measurement, but a rating, developed by a practiced observer, from reports given by the public. Intensity has been correlated roughly with magnitude by the relationship,

$$
M=1+\frac{2}{3} I_{0}
$$

however, this implies that the intensity is a true numerical quantity which in fact it is not. 
TABLE 1

Earthquake Measurements -

Modified Mercalli Intensity Scale (1956 Version) ${ }^{a}$

Intensity,

MM

I

I I

I I I

IV

$\mathrm{V}$

VI

VII

\section{Description}

Not felt. Marginal and long-period effects of large earthquakes.

Felt by persons at rest, on upper floors, or favorably placed. Average ground motion, $0.23 \% \mathrm{~g}$; ground motion range, 0.1 to $0.5 \% \mathrm{~g}$.

Felt indoors. Hanging objects swing. Vibration; like passing of light trucks. Duration estimated. May not be recognized as an earthquake. Average ground motion, $0.31 \% \mathrm{~g}$; ground motion range, 0.1 to $0.8 \% \mathrm{~g}$.

Hanging objects swing. Vibration; like passing of heavy trucks, or sensation of a jolt like a heavy ball striking the walls. Standing motor cars rock. Windows, dishes, doors rattle. Glasses clink. Crockery clashes. In the upper range of IV, wooden walls and frame creak. Average ground motion, $0.93 \% \mathrm{~g}$; ground motion range, 0.2 to $4.6 \% \mathrm{~g}$.

Felt outdoors, direction estimated. Sleepers wakened. Liquids disturbed, some spilled. Small unstable objects displaced or upset. Doors swing, close, open. Shutters and pictures move. Pendulum clocks stop, start, change rate. Average ground motion, $1.33 \% \mathrm{~g}$; ground motion range, 0.2 to $7.5 \% \mathrm{~g}$.

Felt by all. Many frightened and run outdoors. Persons walk unsteadily. Windows, dishes, glassware broken. Knick-knacks, books, etc., fall off shelves. Pictures fall off walls. Furniture moved or overturned. Weak plaster and masonry D crack. Small bells ring (church, school). Trees, bushes shaken (visibly, or heard to rustle). Average ground motion, $4.0 \% \mathrm{~g}$; ground motion range, 0.5 to $17.5 \% \mathrm{~g}$.

Difficult to stand. Noticed by drivers of motor cars, Hanging objects quiver. Furniture broken. Damage to masonry D, including cracks. Weak chimneys broken at roof line. Fall of plaster, loose bricks, stones, tiles, cornices (also unbraced parapets and architectural ornaments). Some cracks in masonry $C$. Waves on ponds; water turbid with mud. Small slides and caving-in along sand or gravel banks. Large bells ring. Concrete irrigation ditches damaged. Average ground motion, $6.7 \% \mathrm{~g}$; ground motion range, 1.8 to $14 \% \mathrm{~g}$.

a. Ground motion accelerations taken from Reference 14. 


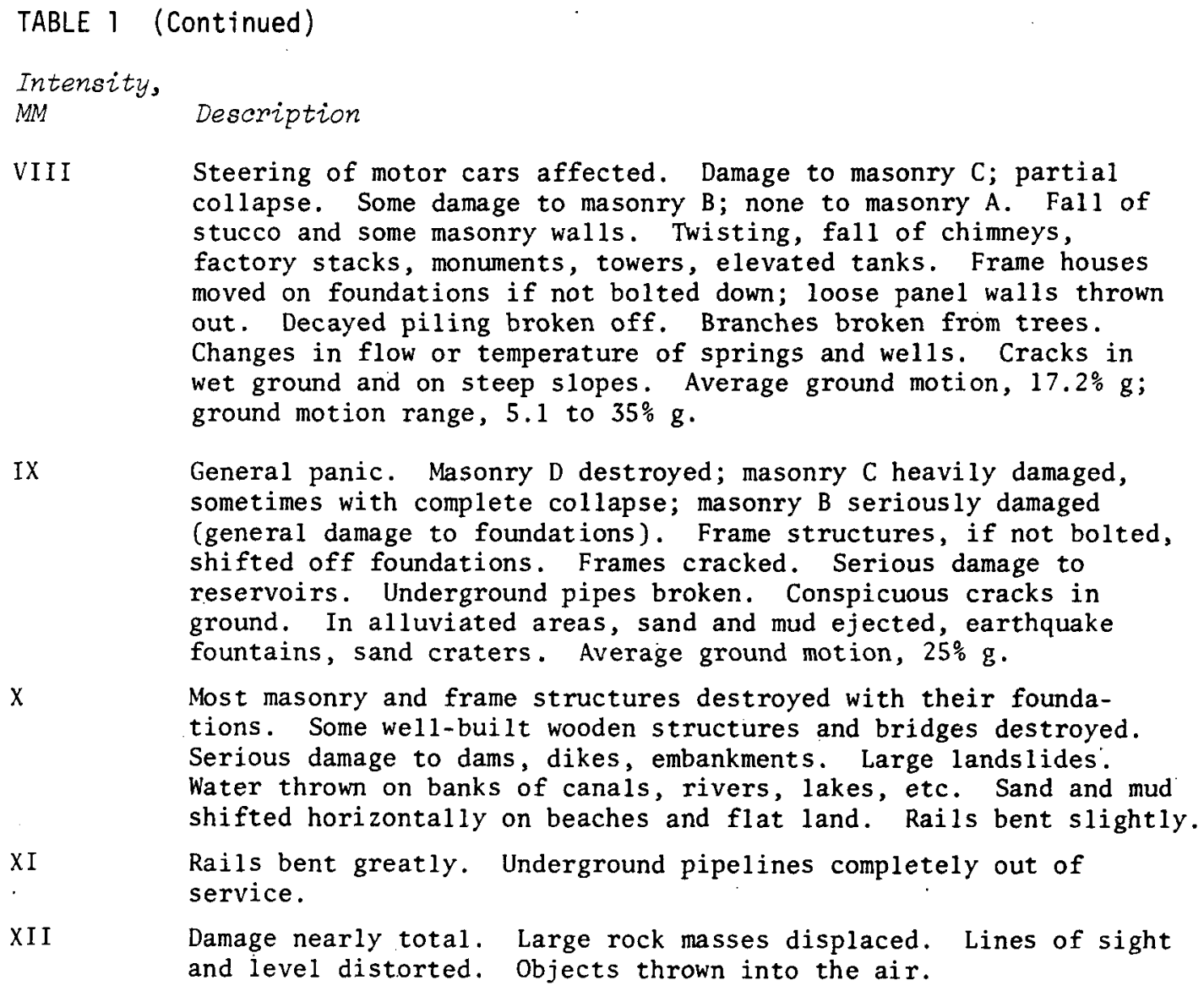

IX General panic. Masonry D destroyed; masonry C heavily damaged, sometimes with complete collapse; masonry B seriously damaged (general damage to foundations). Frame structures, if not bolted, shifted off foundations. Frames cracked. Serious damage to reservoirs. Underground pipes broken. Conspicuous cracks in ground. In alluviated areas, sand and mud ejected, earthquake fountains, sand craters. Average ground motion, $25 \% \mathrm{~g}$.

$X \quad$ Most masonry and frame structures destroyed with their foundations. Some well-built wooden structures and bridges destroyed. Serious damage to dams, dikes, embankments. Large landslides. Water thrown on banks of canals, rivers, lakes, etc. Sand and mud shifted horizontally on beaches and flat land. Rails bent slightly.

XI Rails bent greatly. Underground pipelines completely out of service.

XII Damage nearly total. Large rock masses displaced. Lines of sight and level distorted. Objects thrown into the air.

Masonry A Good workmanship, mortar, and design; reinforced, especially laterally, and bound together by using steel, concrete, etc., designed to resist lateral forces.

Masonry B Good. workmanship and mortar; reinforced, but not designed in detail to resist lateral forces.

Masonry $C$ Ordinary workmanship and mortar; extreme weaknesses, such as failing to tie in at corners. Neither reinforced nor designed against horizontal forces.

Masonry D Weak materials, such as adobe; poor mortar; low standards of workmanship; weak horizontally. 
Earthquake risk maps (Figure 1) have been formulated for the United States based on historical damage to various areas. ${ }^{16,17}$ This map is directly correlative with maps showing the location of major earthquakes (intensity 5 or greater) up through 1970 (Figure 2). ${ }^{18}$ This correlation is due to the fact that the risk map was developed from surface damage associated with historic seismicity; however, how the risk map applies to underground facilities is not yet known.

The resulting velocity, acceleration, and displacement spectra from an earthquake are usually plotted as a function of frequency (period) on a pseudo-velocity diagram. These plots are helpful in evaluating and designing surface structures. Figure 3 shows a plot of site-independent spectra from several sources. ${ }^{19}$

Relationships of surface acceleration (Figure 4$)^{4}$ and velocity (Figure 5$)^{20}$ have been established as a function of intensity and magnitude with distance. The relationships between predominant period and magnitude are shown as a function of distance (Figure 6). ${ }^{19}$

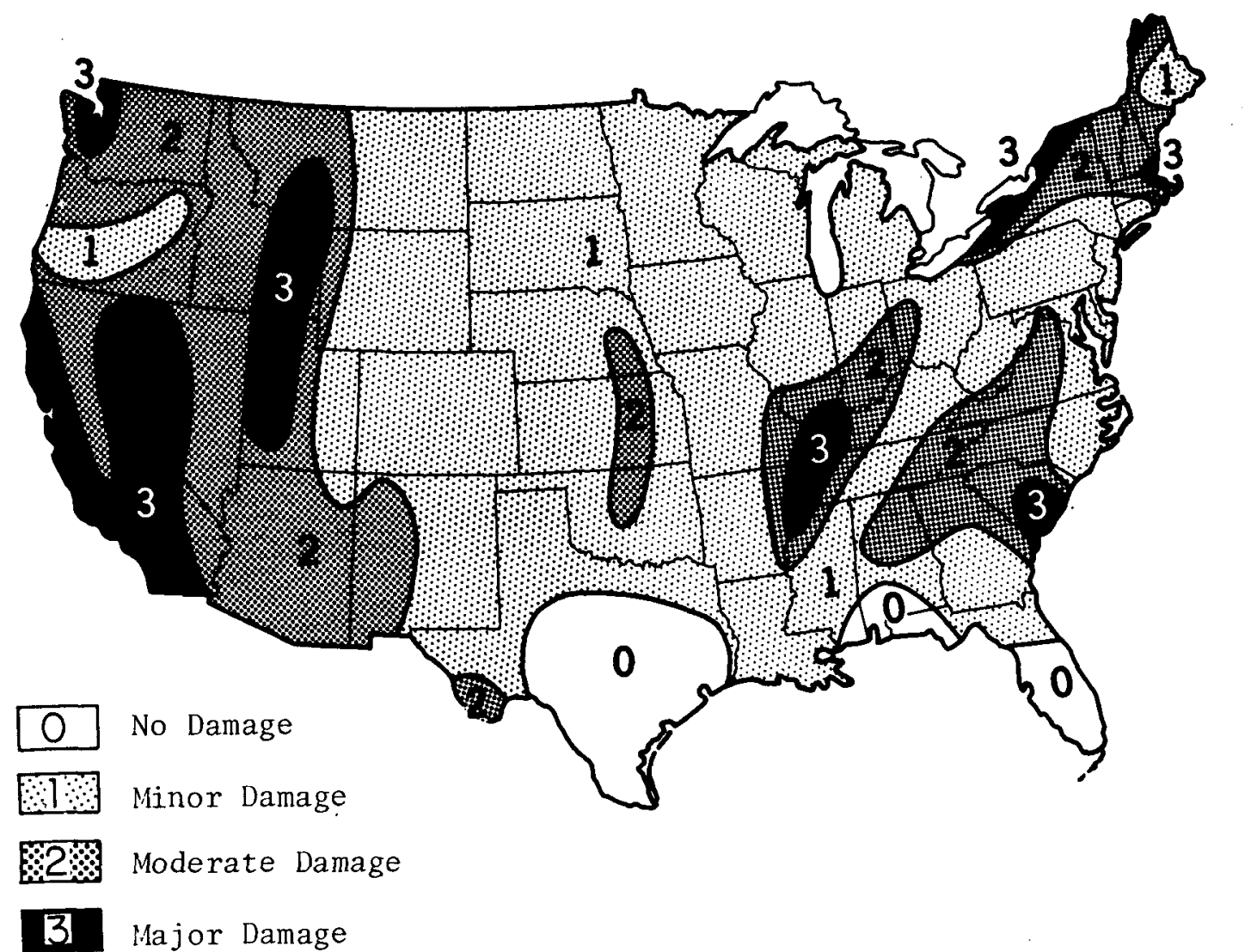

FIGURE 1. Risk of Damage from Earthquakes in the United States ${ }^{16}$ 


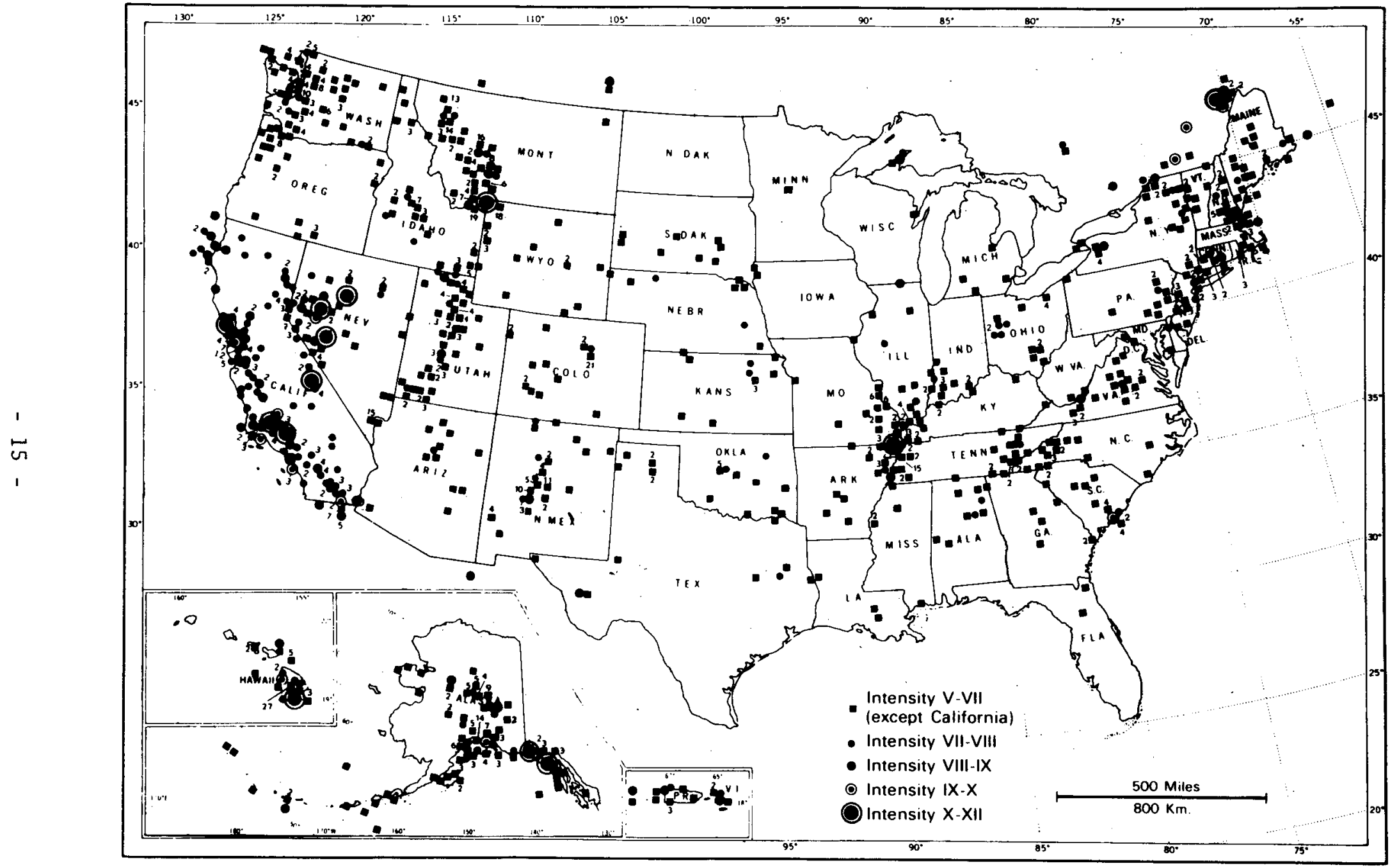

FIGURE 2. Earthquakes (Intensity $V$ and Above) in the United States
Through $1970^{18}$ 


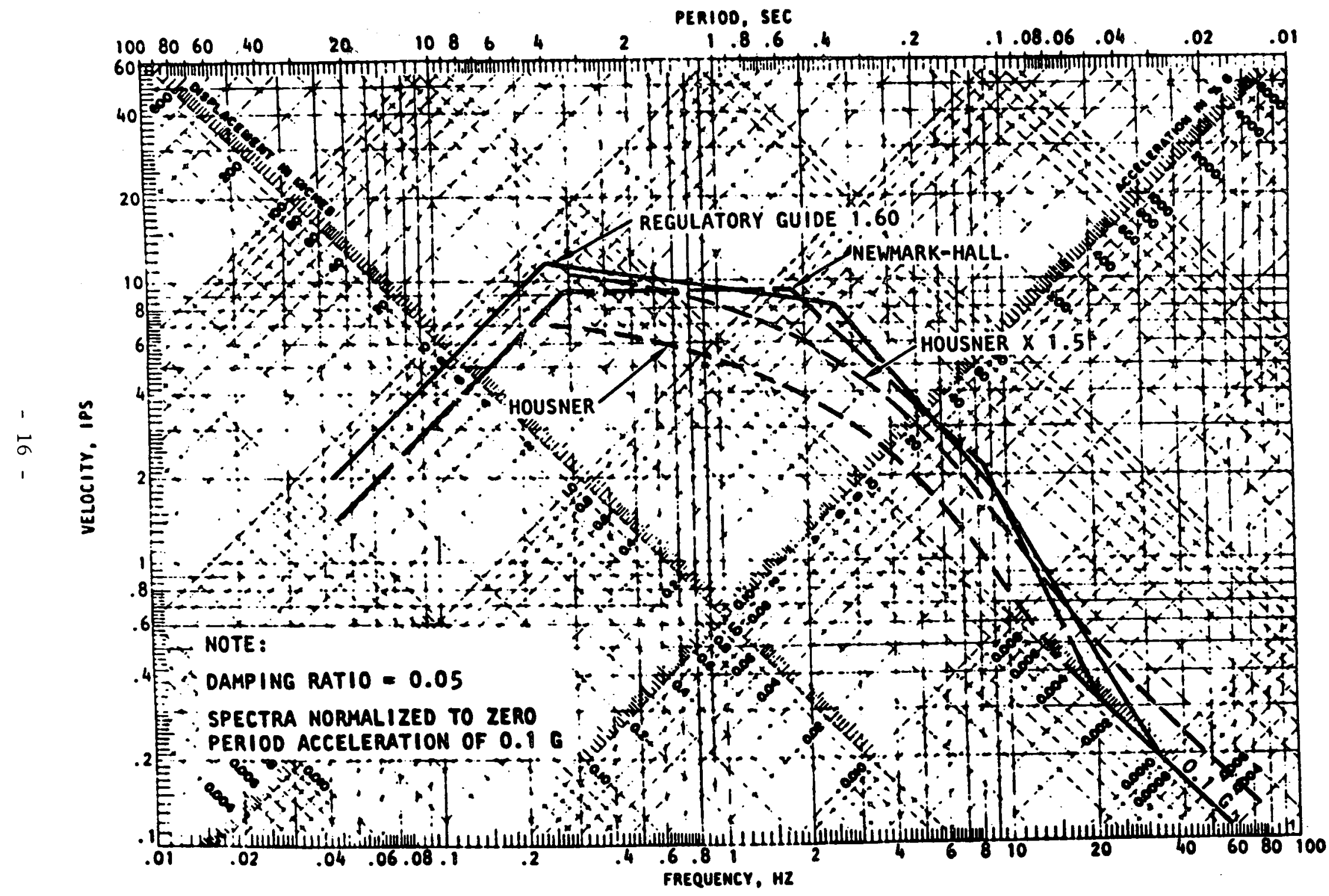

FIGURE 3. Comparison of Site-Independent Spectra ${ }^{19}$ 


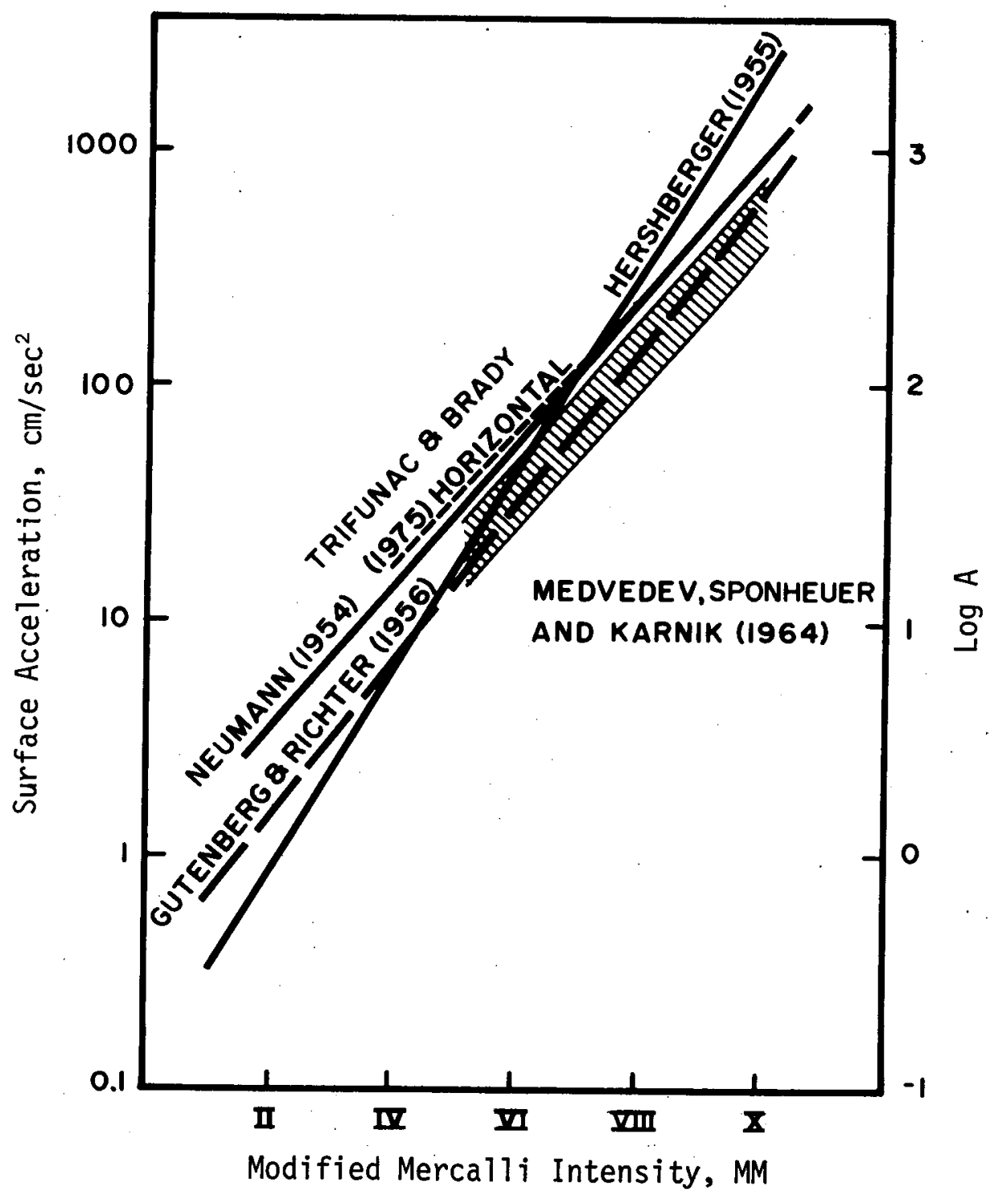

FIGURE 4. Surface Acceleration Versus Intensity ${ }^{2}$ 


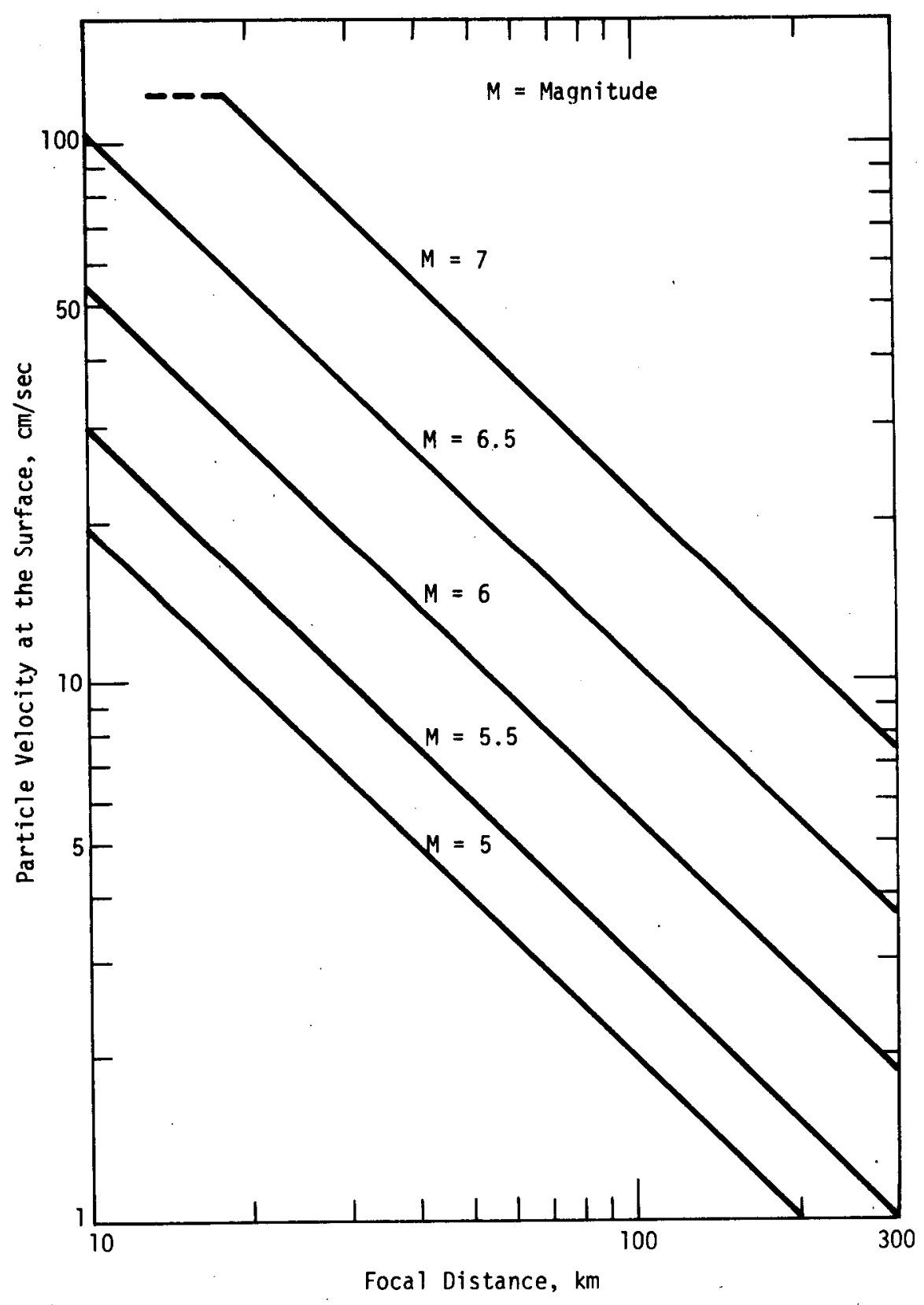

FIGURE 5. Maximum Probable Ground Velocities ${ }^{20}$ 


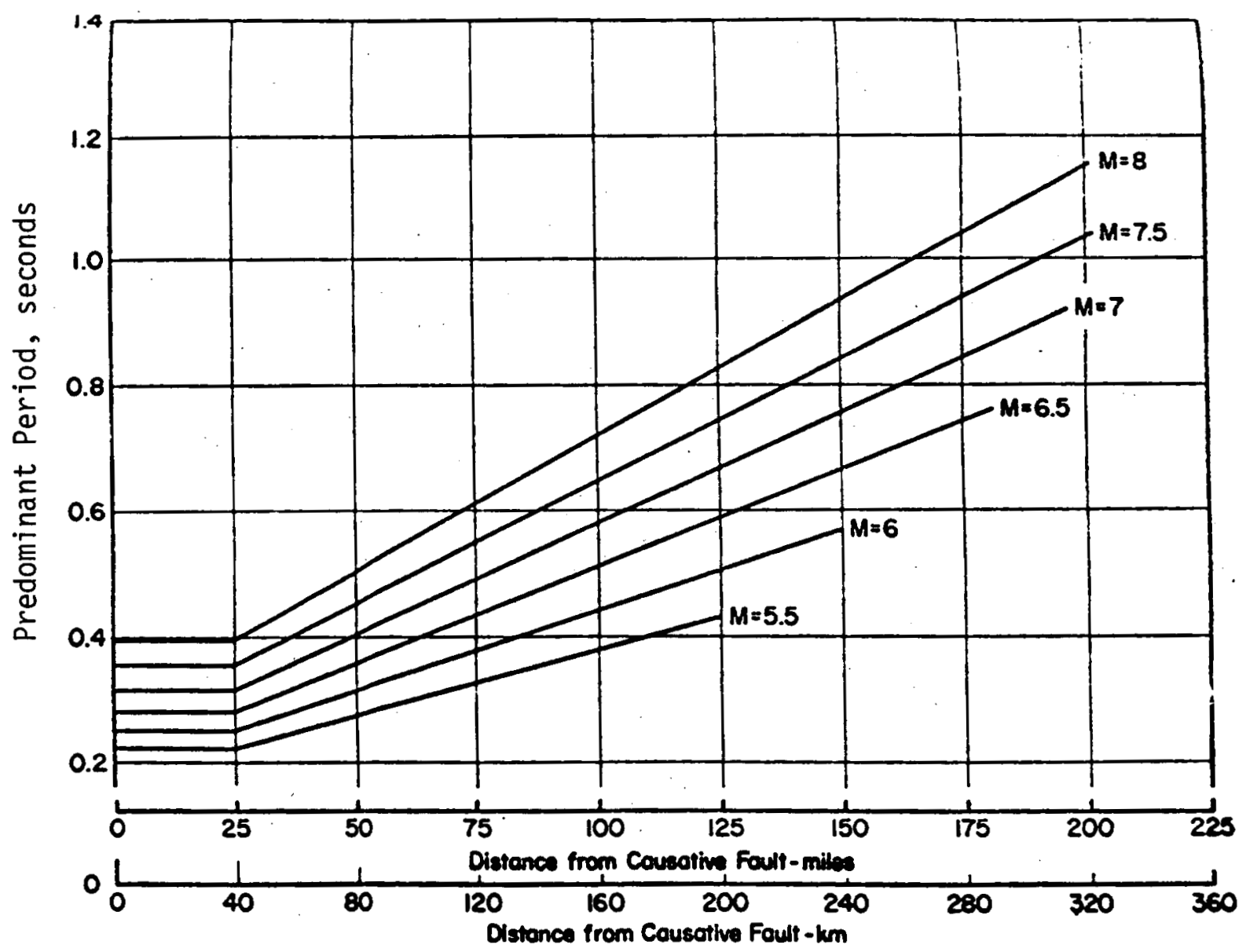

FIGURE 6. Predominant Periods for Maximum Acceleration in Rock ${ }^{19}$ 


\section{EXISTING DATA BASE ON EARTHQUAKE DAMAGE}

\section{Tunnels and Shallow Underground Openings}

Data on the seismic stability and behavior of shallow underground openings are very well summarized in a thesis by Rozen ${ }^{2}$ and in a paper by Dowding. ${ }^{3}$ Observations from 71 tunnels responding to earthquake motions were compared. Dynamic behavior was compared with intensity and magnitude as a function of distance. The cases which are discussed in detail in Rozen's thesis are given in Appendix A. The studies compared calculated accelerations at the ground surface with tunnel damage and show that the tunnels are less susceptible to damage than surface structures or facilities. Peak accelerations at the surface of less than $0.2 \mathrm{~g}$ did not damage the tunnels; between 0.2 and $0.5 \mathrm{~g}^{\prime} \mathrm{s}$, damage was only minor; and damage was significant only above $0.5 \mathrm{~g}$ (Figure 7 ).$^{2,3}$ Most of the damage that occurred was located near a portal. Richter magnitude as well as Modified Mercalli intensity is correlated with acceleration for various cases in Figure $8 .^{2,3}$ Large accelerations are correlative with large magnitudes and high intensities. At any one specific site, calculations of accelerations were based upon the earthquake magnitude and the epicentral distance through attenuation laws developed by McGuire ${ }^{21}$ and shown in Figure $9.2,3$ The calculated peak acceleration, velocity, and displacement levels given in Appendix A are at surface, and no reduction was made for attenuation with depth. Rozen ${ }^{2}$ correlated peak surface motion and related intensity levels with observed underground damage.

Variation and attenuation of peak surface accelerations with distance show the relatively large spread depending on the model and the data base used (Figure 9). ${ }^{2,3}$ The variation in attenuation is further complicated because of the variety of geologic environments from which the data were gathered. The peak velocity attenuation is also a function of focal distance (Figure 10). ${ }^{2}$ The attenuation curves of $\operatorname{Seed}^{22}$ for a wide range of earthquake magnitudes do not show a great deal of difference between rock and alluvium. But the results in rock at $300-\mathrm{m}$ depth by $\mathrm{Kanai}^{23}$ indicate that initial peak velocities are lower by a factor of $\sim 2$ at depth. More detailed acceleration attenuation curves from a variety of sources are given in Figure $11 .^{2}$

The data of Rozen ${ }^{2}$ summarized in the work by Dowding ${ }^{3}$ indicate that: (1) experience shows that tunnels are more stable than structures located on the surface; (2) critical frequencies are lower for large underground chambers than tunnels because of the increase in the size of underground chambers; and (3) if the rock mass is considered continuous, the resonant circulation of surface waves in the larger chambers cannot occur at frequencies below $100 \mathrm{~Hz}$. 


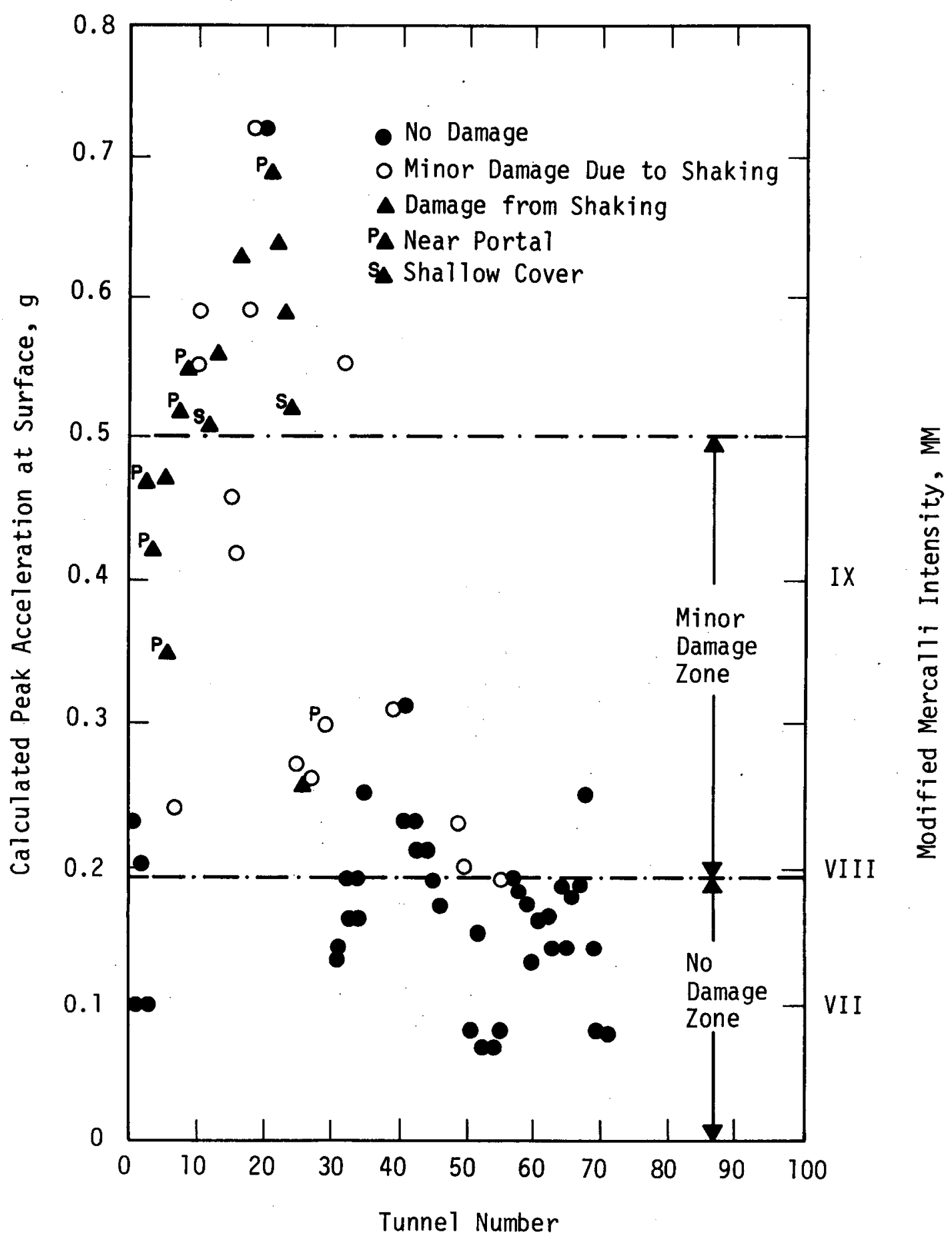

FIGURE 7. Calculated Peak Acceleration at the Surface and Associated Tunnel Damage ${ }^{2,3}$ 


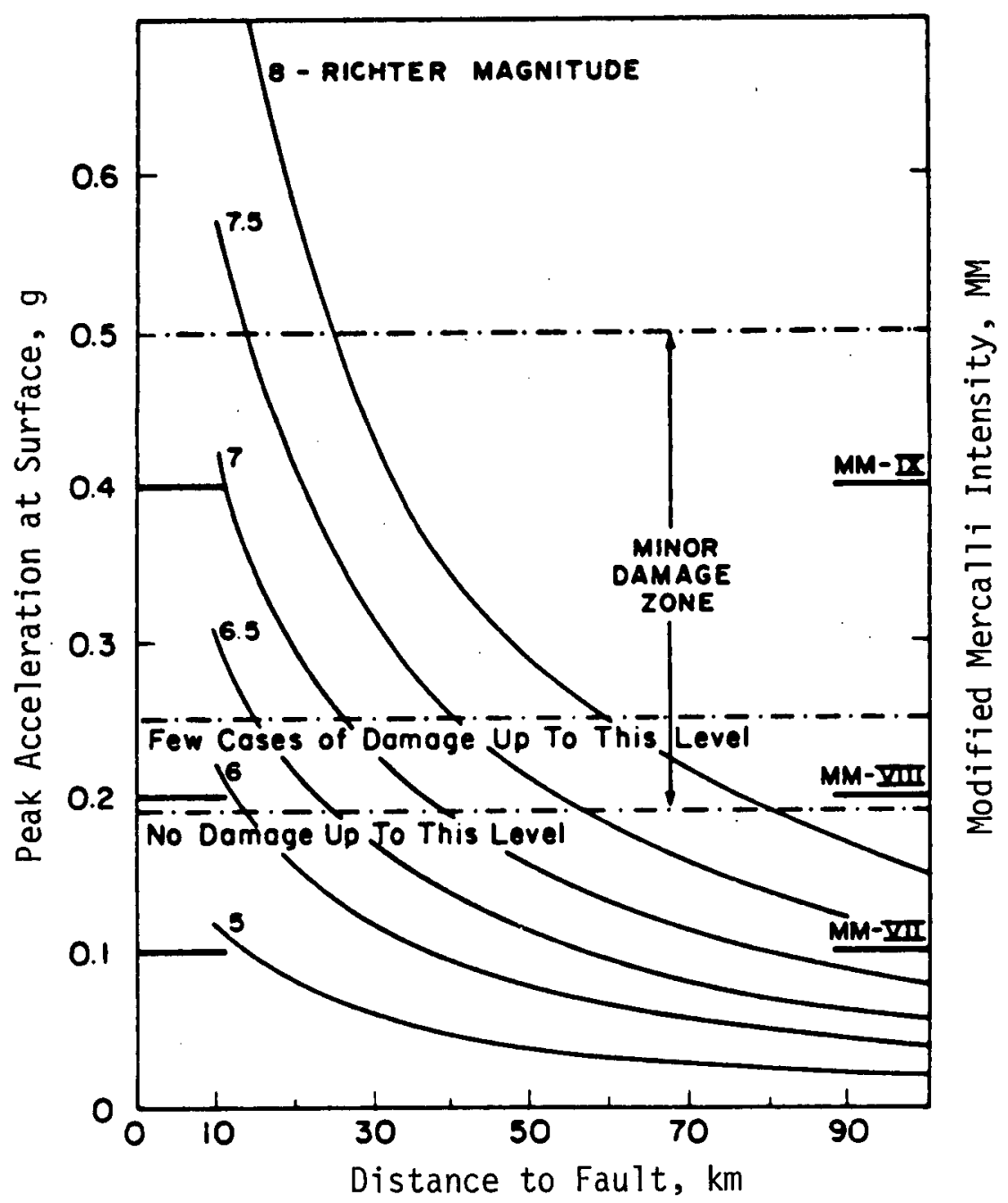

FIGURE 8. Accelerations, Modified Mercalli Intensity, and Associated Tunnel Damage ${ }^{2,3}$ 


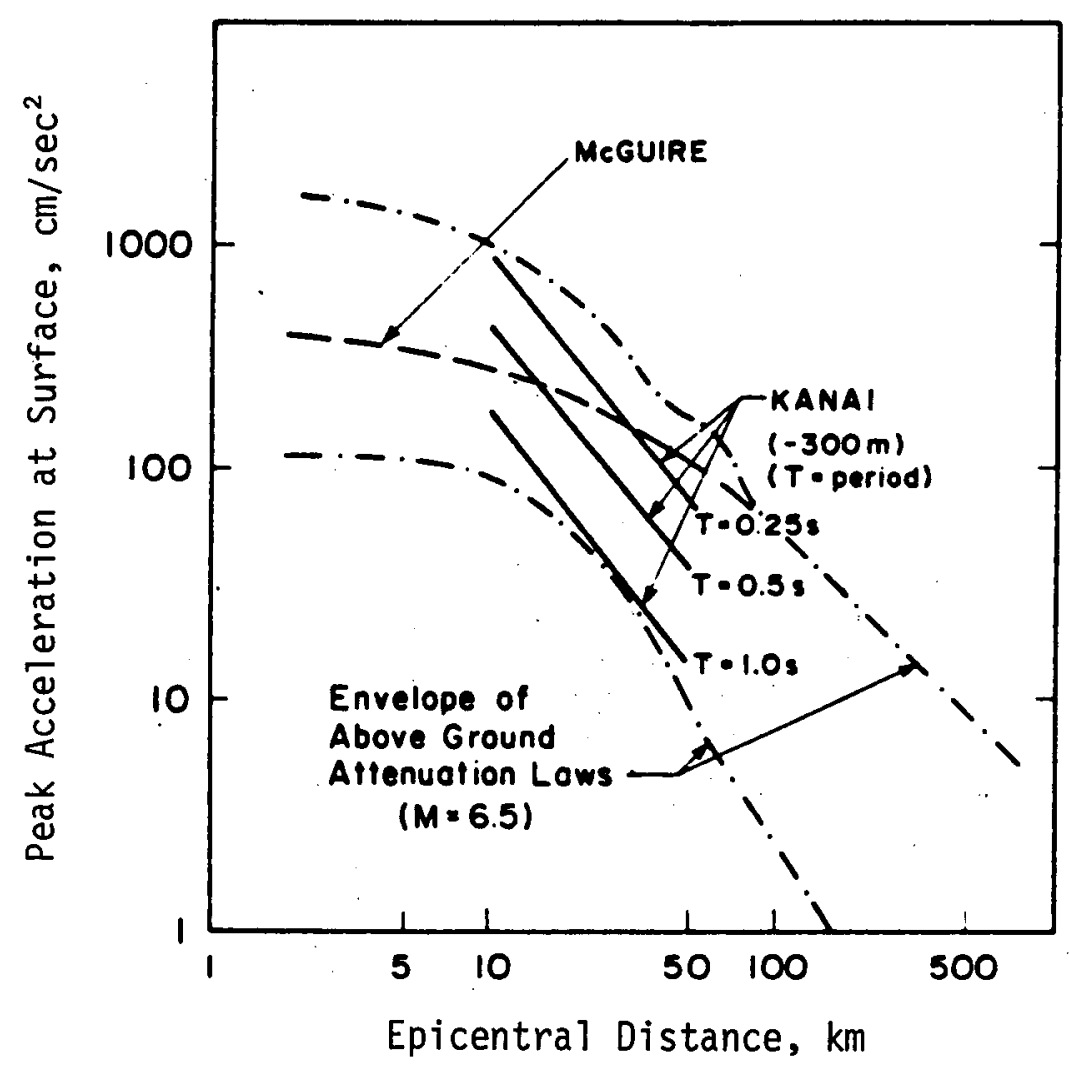

FIGURE 9. Spread of Attenuation Relationships for Magnitude 6.5 Earthquake 2,3 


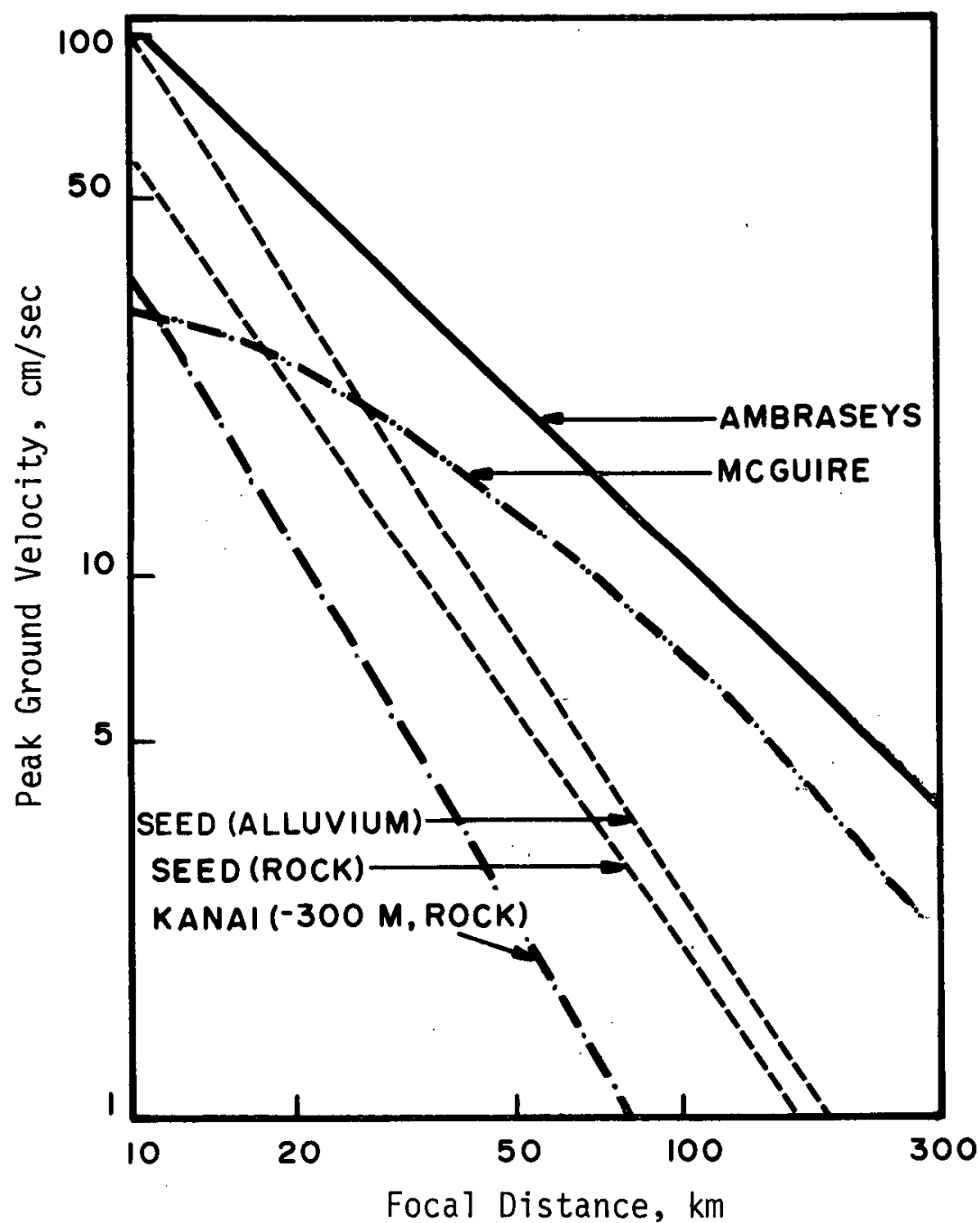

FIGURE 10. Velocity as a Function of Focal Distance for Various Site Conditions ${ }^{2}$ 


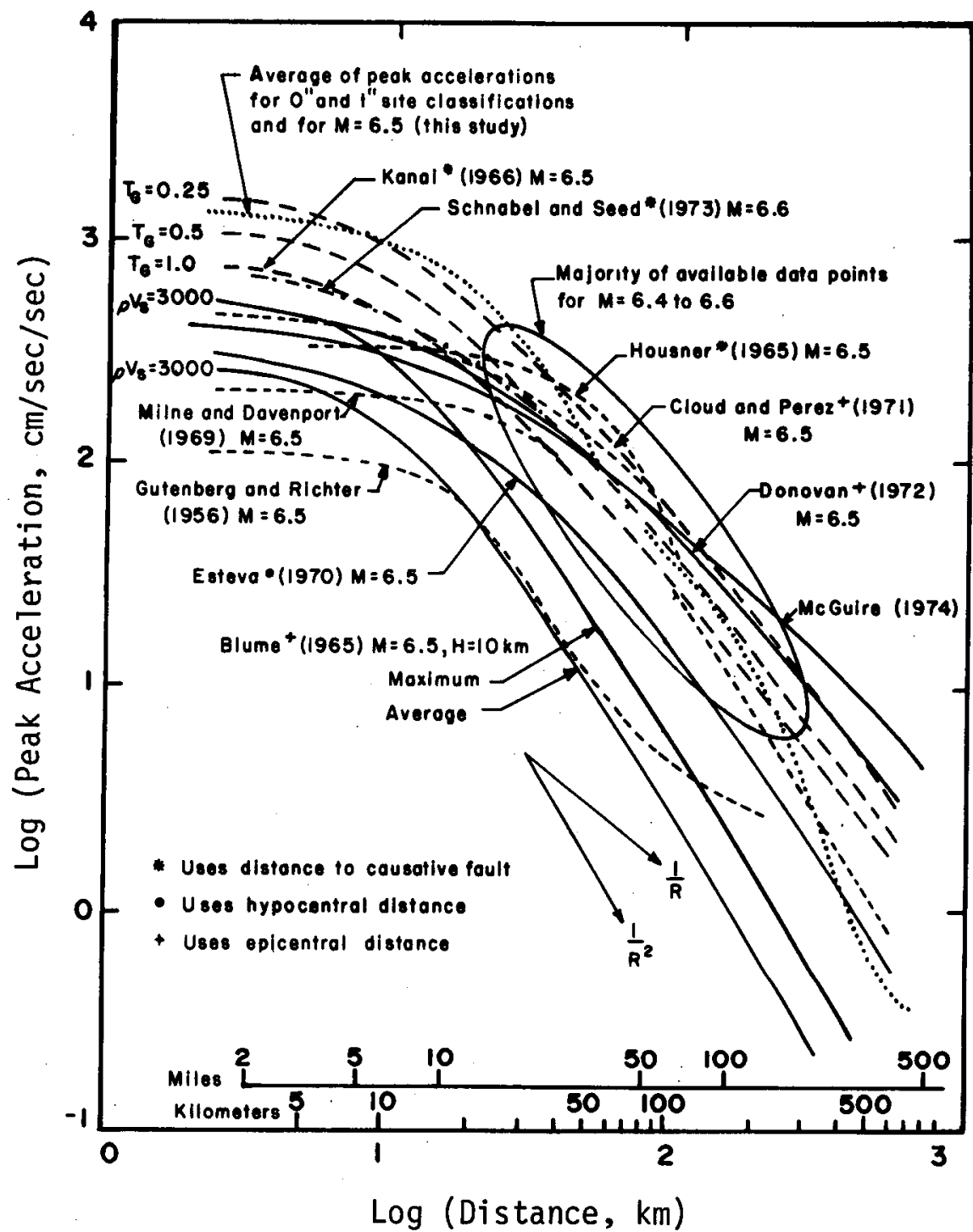

FIGURE 11. Various Relationships Between Peak Acceleration and Distance from Source for Magnitude 6.5 Earthquakes ${ }^{2}$ 
The conceptual designs of a waste repository indicate that its configuration will probably be $\sim 10$ meters, rather than 100 , in diameter; hence, the following conclusions are: (1) critical frequencies calculated from Rozen's data ${ }^{2}$ for underground openings of this size are $\sim 150 \mathrm{~Hz}$, and, therefore, threshold damage would not occur unless the repository was relatively close to the epicenter; (2) peak motions may be selectively amplified on a frequency basis; (3) the dynamic stress concentrations are probably no more than $20 \%$ greater than those caused by the opening; and (4) perhaps most importantly, that the primary cause of failure of these underground excavations is relative movement along pre-existing faults, or at the portal of the tunnel which is located at ground surface.

Duke and Leeds ${ }^{l}$ reviewed information on tunnel damage as well as some mine damage due to earthquakes and drew the following conclusions.

- Severe tunnel damage appears to be inevitable when the tunnel is crossed by a fault or fault fissure which slips during the earthquake.

- In tunnels away from fault breaks, severe damage may be done by shaking to linings and portals and to the surrounding rock, for tunnels in the epicentral region of strong earthquakes, where construction is of marginal quality. Substantial reinforced-concrete lining has proved superior to plain concrete, masonry, brick, and timber in this regard.

- Tunnels outside the epicentral region and well-constructed tunnels in this region but away from fault breaks can be expected to suffer little or no damage in strong earthquakes.

- Although it would seem reasonable that competence of the surrounding rock would reduce the likelihood of damage due to shaking, inadequate comparative evidence is available on this point.

- Within the usual range of destructive earthquake periods, intensity of shaking below ground is less severe than on the surface.

The following tunnel data are the major examples of damage reported by Duke and Leeds. ${ }^{1}$

San Francisco Earthquake, 1906

In the San Francisco earthquake of 1906, the Wright's number 1 and number 2 tunnels on the narrow gage Southern Pacific Railroad were damaged. The $1863-\mathrm{m}$ long number 1 tunnel, located in the Santa Cruz Mountains at a depth of $214 \mathrm{~m}$, was offset $1.37-\mathrm{m}$ transverse horizontal where it crossed the San Andreas fault. Other damage included the caving of rocks from the roof 
and sides, the breaking of upright timbers, the heaving upward of rails, and the breaking of ties. The second tunnel, directly south, near Glenwood, was $1737 \mathrm{~m}$ long and $207 \mathrm{~m}$ deep. It did not cross the fault and was less damaged; timbers were broken and the roof caved, blocking the tunnel at several points.24,25 Other tunnels in the same area were undamaged.

Tokyo Area, 1923

Damage occurred to 25 tunnels close to the epicenter. This damage was attributed to shaking and not to fault movement. However, the construction, character of rock, length, and other features of the tunnels varied widely. Beyond the isoseismal corresponding to approximately $50 \%$ of the houses collapsed, tunnel damage apparently was insignificant.

Japan Earthquake, 1930

The Tanna tunnel was under construction at the time of the earthquake. A transverse offset of $2.3 \mathrm{~m}$ was recorded along a fault in one of the drain tunnels which extended ahead of the main tunnel heading. The only damage to the main tunnel was a few cracks in the walls. The depth was $\sim 160 \mathrm{~m}$; accelerations were not available, but $55 \%$ of the houses were destroyed at the surface above. The basin was composed of unconsolidated materials to $\sim 40 \mathrm{~m}$. The rock at a depth of $140 \mathrm{~m}$ was volcanic andesite. Fault displacements at the surface were less than the $2.3 \mathrm{~m}$ that was measured in the drain tunnel, but this may have been because movement was diffuse in the unconsolidated material near the surface.

Kern County Earthquake, 1952

Kern County, California earthquake of 1952 damaged four tunnels on the Southern Pacific railroad near Tehachapi. This was a region of large ground fractures with movement along the White Wolf fault. This is another case where the subsurface damage was greater than that on the surface. These tunnels were in the epicentral region, but the extensive damage was attributed to their location in the fault zone where displacements exceeded those at the surface. $26,27,28$

In 1966, a resurvey of the Claremont Water tunnel near Berkeley, California revealed three cracks in the tunnel at its intersection with the Hayward fault zone, which were not present when the tunnel was surveyed in $1950 .{ }^{29}$ The tunnel is $\sim 46 \mathrm{~m}$ beneath the surface at this point and shows right lateral offset of $168 \mathrm{~mm}$ since its construction. Of this amount, only $48 \mathrm{~mm}$ 
could be accounted for as displacement due to fracture of the lining. The remaining $119 \mathrm{~mm}$ is accounted for as flexure of the lining. The offset takes place in a segment of the tunnel $<30 \mathrm{~m}$ in length. Displacement of the tunnel is not known to be associated with any seismic event, and except for buckling of the invert in the zone of fracture, no indication of vertical displacement is found. Because of this, the displacement probably reflects gradual creep along the fault zone.

Duke and Leeds ${ }^{1}$ report that with the exception of damage caused by the 1906 and 1952 earthquakes, as reported above, no other reports of tunnel damage were discovered after reviewing over 215 tunnels in California including one that crosses the San Andreas fault. They conclude that this experience is significant because severe earthquakes occurred in 1915 (Imperial Valley), 1925 (Santa Barbara), 1933 (Long Beach), 1940 (E1 Centro), and 1954 (western Nevada).

\section{Mines or Other Deep Structures}

The damage from earthquakes to underground mines has been documented in several places. Reports have generally been qualitative in nature and recounted from incidents in which damage has been assessed either by those working in the mine or by people that have visited the mines subsequent to the earthquake. Quantitative data have been much more difficult to obtain and come primarily from a few sources. Most of these data are in the form of displacements or accelerations noted in mines in Japan, South Africa, and/or the United States. Recent Japanese data were obtained from Nishimatsu. ${ }^{30}$

The earlier Japanese work has been summarized by Duke and Leeds. ${ }^{1}$ Several Japanese investigators measured earthquake motion at depth and simultaneously at the surface. Nasu ${ }^{31}$ determined the ratio of displacement due to earthquakes at the surface and in tunnels at depths of up to $160 \mathrm{~m}$. One of the most striking was the $2.3-\mathrm{m}$ transverse horizontal offset $0.6 \mathrm{~m}$ beyond a tunnel heading during the 1930 Tanna earthquake. Surface/ depth displacement ratios were $4.2,1.5$, and 1.2 for periods of $0.3,1.2$, and 4 seconds, respectively. The geology consisted of lake deposits at the surface and volcanic andesite and agglomerates at 160-m depth. Nasu concluded that underground motion may be four times less than at the surface.

Kanai ${ }^{32-34}$ measured accelerations at depths up to $600 \mathrm{~m}$ in a copper mine in Paleozoic rock in Hitachi, but unfortunately recorded data were from small earthquakes. The ratio of surface maximum displacement to that at 300-m depth was about $6: 1$ at the mine and about 10:1 on the surface at a school $\sim 6 \mathrm{~km}$ away on 
alluvium. Many earthquakes occurred where the ratio of surface to subsurface displacements were three times the above ratios. Displacements in these cases were exceedingly small because of the small nature of the earthquake measured. Kanai suggested the following attenuation laws with depth to $300 \mathrm{~m}$ as equations of the best fit curve to the data.

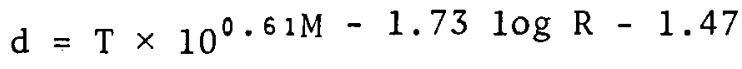

$$
\begin{aligned}
& v=2 \pi \times 10^{0.61 M}-1.73 \log R-1.47 \\
& \mathrm{a}=\frac{(2 \pi)^{2}}{\mathrm{~T}} 10^{0.61 \mathrm{M}}-1.73 \log \mathrm{R}-1.47
\end{aligned}
$$

where

$$
\begin{aligned}
& \mathrm{d}=\text { displacement }, \mathrm{cm} \\
& \mathrm{v}=\text { velocity, } \mathrm{cm} / \mathrm{sec} \\
& \mathrm{a}=\text { acceleration, } \mathrm{cm} / \mathrm{sec}^{2} \\
& \mathrm{~T}=\text { period of the wave } \\
& \mathrm{M}=\text { magnitude } \\
& \mathrm{R}=\text { distance from the earthquake }
\end{aligned}
$$

Okamoto ${ }^{35}$ also measured acceleration both at the surface and at depth. Acceleration records from the surface and at $38 \mathrm{~m}$ show the marked decrease in amplitude with depth (Figure 12). ${ }^{36}$ Based on his findings, he suggested an attenuation law to $67 \mathrm{~m}$ in tuff.

$$
\log _{10} \frac{a_{\max }}{640}=\frac{R+40}{100}\left(-7.604+1.724 \mathrm{M}-0.1036 \mathrm{M}^{2}\right)
$$

The Japanese observations indicate:

- For short periods, surface displacements are greater than underground displacements.

- The ratios of surface to underground displacements (to depths of $600 \mathrm{~m}$ ) were dependent on surface geology, with a ratio of $10: 1$ in alluvium at the surface.

- For long period waves, greater than one second, the ratio of surface to underground displacement approaches unity as period increases.

- These data indicate that for a particular geology, a certain average period of a seismic wave produces a maximum surfaceto-underground displacement ratio. 


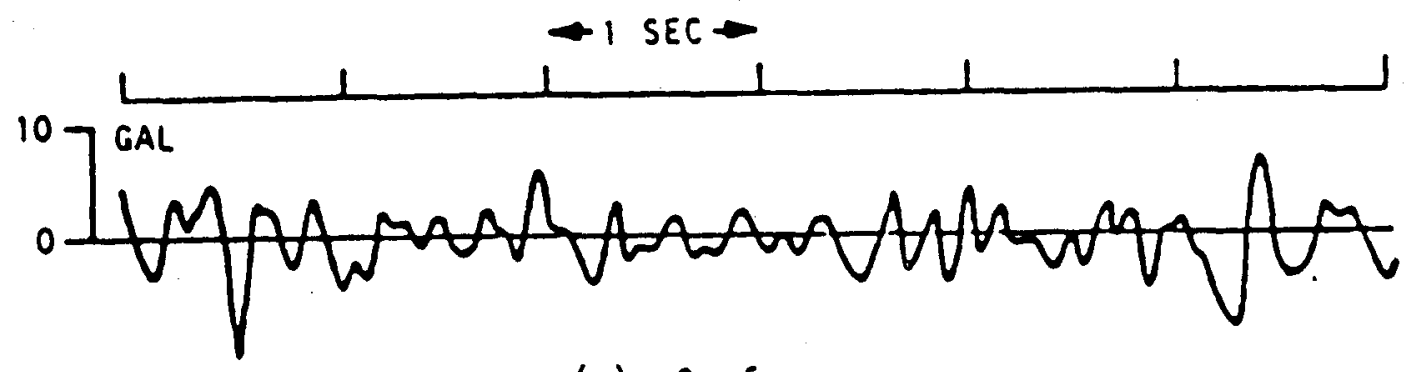

(a) Surface

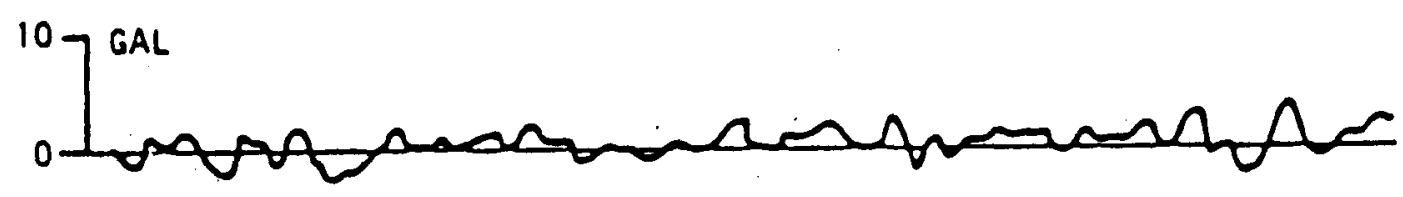

(b) $38 \mathrm{~m}$ underground

FIGURE 12. Acceleration Records Taken on the Surface and $38 \mathrm{~m}$ Underground at Sudagai, Northern Gumma Perfecture, Japan ${ }^{35}$

Carder ${ }^{36}$ reported that for the measurements made on the surface and at 1524-m depth at the Homestake Mine, microseismic events had periods of 4 to 5 seconds. In later studies, P-waves of one second were recorded at the 91-m depth in the Homestake Mine with twice the amplitude of that recorded at a 1524-m depth. Recent studies by Brady ${ }^{37}$ have indicated that seismic activity is noted prior to rock bursts, and some of these rock bursts have magnitudes of 3 to 4 . Damage has been significant in a few of these cases. These small mining-related earthquakes fit a fault length precursor time plot at the lower end of the spectrum (Figure 13). ${ }^{37}$ At the upper end of the spectrum are the large earthquakes at Niigata, Japan, San Fernando, California, and several locations in the U.S.S.R.

Information on earthquake damage from South Africa was obtained during discussions with U.S. Geological Survey personnel. On December 16, 1976, a damaging earthquake of magnitude 5.0 to 5.5 was recorded at Welkom, South Africa. A schematic structure section of the area is shown in Figure 14. The surface damage was extreme, with large structures failing. Displacements $\leq 10 \mathrm{~cm}$ were noted in the mine at a depth of $2.0 \mathrm{~km}$. The focal depth of the earthquake was $26 \mathrm{~km}$. 


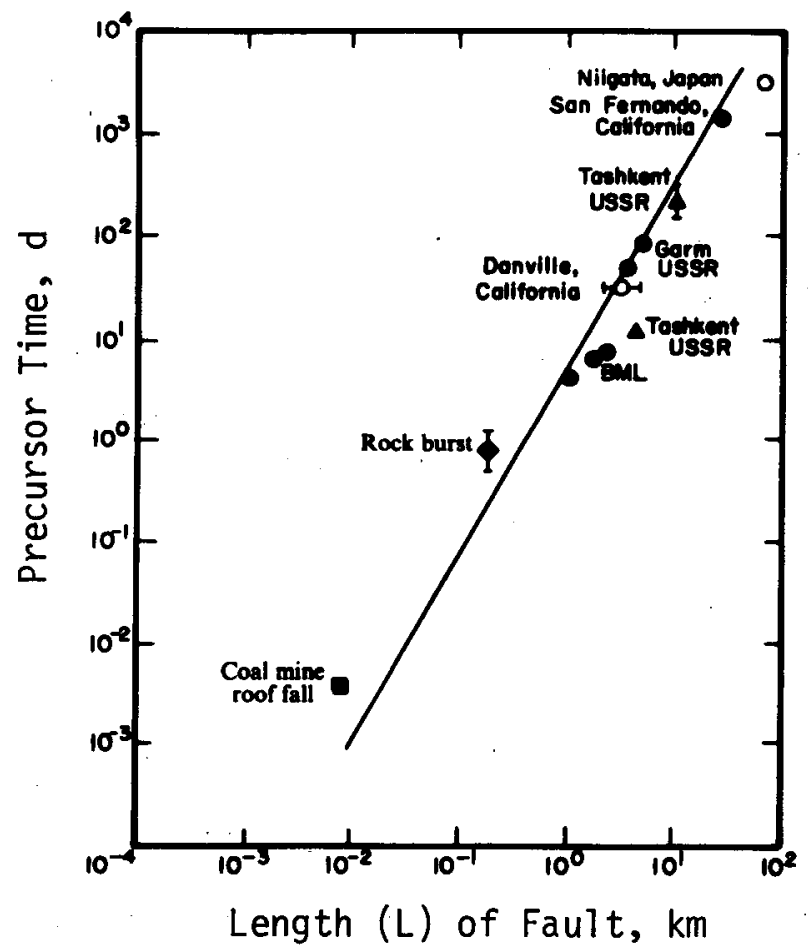

FIGURE 13. Precursor Time for Several Different Failures as a Function of Source Dimension ${ }^{37}$

WELKOM, SOUTH AFRICA

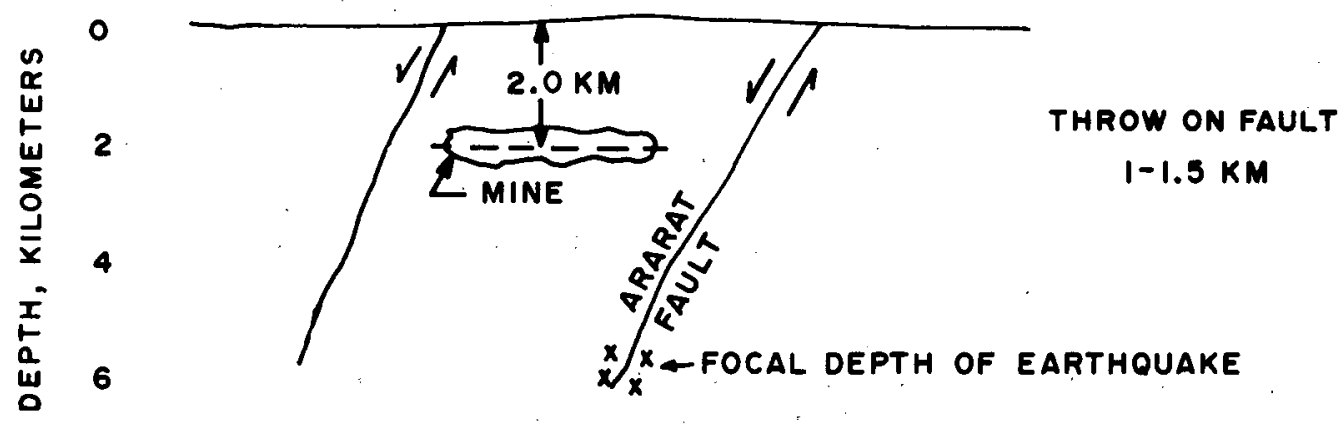

FIGURE 14. Schematic Cross Section of Structural Setting of Earthquake at Welkom, South Africa, December 1976 
In both the Rand Gold district and the Orange Free State district, studies were conducted to assess the relationship of acceleration, displacement, and frequency of earthquakes to magnitude during the mining operation. These mines are up to $4 \mathrm{~km}$ in depth. McGarr ${ }^{38}$ noted that shear displacements on the order of 5 to $10 \mathrm{~cm}$ were associated with magnitude of 2 to 3 rock bursts due to resulting stress redistribution. It must be emphasized that these displacements were measured once the area was mined so these displacements represent relative movement in intact rock away from a free surface. These data are very important and may give us, along with the data at Welkom, some indications of upper bounds of displacements. near earthquake sources in these very hard rocks.

The U. S. G. S. ${ }^{39}$ reported in the lessons and conclusions of the Alaskan earthquake of 1964 that no significant damage was reported to underground facilities, such as mines, and tunnels, as a result of the earthquake, although some rocks were shaken loose in places. Included in this analysis were studies of the coal mines in the Matanuska Valley which were undamaged, the railroad tunnels near Whittier, the tunnel and penstocks at the Eklutna hydroelectric project, and the Chugach Electric Association tunnel between Cooper Lake and Kenai Lake. There were also no reports of damage to the oil and gas wells in and along Cook Inlet.

The reports of non-damage from the Alaskan earthquake are significant. This earthquake was one of the largest $(M=8.5)$ to occur in this century, and surface damage was extreme.

Stevens ${ }^{40}$ summarizes the nature and geography of earthquakes and gives numerous examples pertaining to the effects of earthquakes on underground structures. Because instrumentally derived seismological data have been available for only about 70 years, the principal sources for the reports are eyewitness accounts; these made it exceedingly difficult to quantify the effects of the earthquakes. The following incidents from Stevens concentrate on those events which had significant effects on the surface or in the subsurface, and also on those which have quantitative data associated with them.

An earthquake was reportedly felt $457 \mathrm{~m}$ underground at Virginia City, June $6,1868.40$ Observers state that during an -earthquake at Virginia City, the mines were not caved in or damaged; however, in some mines, the flow of water was greatly increased, while at Gold Hill, it was generally diminished.

On August 22, 1952, the strong aftershock of the Kern County earthquake caused concern for a party touring through Crystal Cave. The quake was felt generally in the area of Sequoia 
National Park; however, no one in the party underground noticed the earthquake.

During the 1960 Chilean earthquake, one of the strongest earthquakes on record, miners in coal mines heard strange noises but felt no effects of the quake. Later examination of these mines, which extend under the ocean, showed several old faults, but no new movement. ${ }^{40}$

Stevens ${ }^{40}$ has several general conclusions:

- Effects on mines are less severe than surface effects.

- Severe damage is inevitable when a mine or tunnel intersects a fault along which movement occurs during an earthquake.

- Mines in epicentral region of strong earthquakes, but not transected by fault movement, may suffer severe damage by shaking. Stevens did not define the word severe quantitatively.

- Mines outside of epicentral regions are likely to suffer little or no damage from a strong earthquake.

- Damage to mines is most insignificant when they are located in highly competent, unweathered rock; greatest damage occurs in mines found in loose unconsolidated or incompetent rock. This is due to the diminished effect of shaking in competent rock; unconsolidated sediment is much more susceptible to damage caused by shaking.

Similar results were reported by Cooke ${ }^{1}$ for the Peru earthquake of May 31, 1970. The earthquake of Richter magnitude 7.7 did no damage to 16 railroad tunnels totaling $1740 \mathrm{~m}$ under little cover in zones of MM VII to VIII intensity. Also no damage was reported to the underground works of a hydroelectric plant and 3 coal and 2 lead zinc mines in the MM VII intensity zone.

A number of mines are located in areas where earthquakes frequently occur; however, many of these areas are not studied scientifically, and so reports of possible damage do not exist. Japan is particularly significant because it is highly seismic, and records should exist. Europe is less seismic, but it too has been carefully investigated.

A summary of recent (1977) data from foreign sources based on personal communication and literature is presented below. 
In Europe, we were unable to find any significant reports of damage to deep underground structures and mines due to earthquakes. We have corresponded with seismologists primarily in Switzerland and Germany, but records of damage do not exist. ${ }^{42}$

Professor K. Mogi of the Earthquake Research Institute reported that he knew of no damage in mines in Japan. ${ }^{43}$ However, Professor $\mathrm{K}$. Aki at Massachusetts Institute of Technology noted that a railroad tunnel on the main Tokyo line was offset during the 1930 Kita Izu earthquake nearby. ${ }^{44}$ Professor Y. Nishimatsu ${ }^{30}$ of the Engineering Faculty at the University of Tokyo reported that there were no records of damage from coal mines near the epicenter of the Tokachi Oki earthquakes of 1952 and 1968. One mine operator reported a small rock burst soon after the 1968 shock, suggesting a possible triggering by the earthquake. The records kept in the coal mines are complete, and the negative report above suggests that, in general, damage due to earthquakes is negligible.

Nishimatsu ${ }^{30}$ has made a finite element study of strain in underground openings. He reported strains of nearly $10^{-6}$ for an acceleration of $50 \mathrm{gal}$ (gal - a unit of acceleration equivalent to one centimeter per second per second).

The Japanese, as reported by Iwasaki et a1. ${ }^{45}$ obtained acceleration records to depths of $150 \mathrm{~m}$ below the surface during a five-year period from bore-hole accelerometers installed at four locations around Tokyo Bay. Three of the sites were in sands and clays; however, the site at Kannonzaki was in a siltstone. During the period of operation, data were obtained from 16 earthquakes ranging in magnitude from 4.8 to 7.2 . The results are presented in Table 2,45 which gives the accelerations recorded at the four sites and the important earthquake parameters.

Iwasaki et al. ${ }^{45}$ concluded from the analysis of the accelerations recorded in the bore holes at the different depths that:

- The distribution of the maximum accelerations, with respect to depths, changes considerably with the change of soil conditions near the ground surface. Ratios of the surface acceleration to that at the deeper layer $(110$ to $150 \mathrm{~m})$ are about 1.5 at a rocky ground, 1.5 to 3 at sandy grounds, and 2.5 to 3.5 at a very clayey ground. 
TABLE .2

Maximum Accelerations (gal) During 16 Moderate Earthquakes Recorded Around Tokyo Bay, $1970-1975^{45}$

\begin{tabular}{|c|c|c|c|c|c|c|c|c|c|c|c|c|c|c|c|c|c|}
\hline \multirow{2}{*}{$\mathrm{EQ}$} & \multirow{2}{*}{$\begin{array}{c}\text { Dete } \\
\text { Megn itude } \\
\text { Epicenter }\end{array}$} & \multirow{2}{*}{ Compo- } & \multicolumn{3}{|c|}{ Futiou Cape } & \multicolumn{4}{|c|}{ Ukishima Park } & \multicolumn{3}{|c|}{ Kannonzaki } & \multicolumn{4}{|c|}{ Ohgishims } & \multirow{2}{*}{ Remark } \\
\hline & & & $0 \mathrm{~m}$ & $-70 \mathrm{~m}$ & $110 \mathrm{~m}$ & $0 m$ & $-27 m$ & $-67 \mathrm{~m}$ & $-127 \mathrm{~m}$ & $0 \mathrm{~m}$ & $-80 \mathrm{~m}$ & $-120 m$ & $0 \mathrm{~m}$ & $-15 \mathrm{~m}$ & $38 \mathrm{~m}$ & $50 \mathrm{~m}$ & \\
\hline 1 & $\begin{array}{c}9.30 .1970 \\
M-4.8 \\
\text { Eastern } \\
\text { Kanegewa-ken }\end{array}$ & $\begin{array}{l}\text { NS } \\
\text { EW } \\
\text { UD }\end{array}$ & $\begin{array}{r}28.2 \\
29.4 \\
8.4\end{array}$ & \begin{tabular}{r|}
6.0 \\
9.8 \\
4.2
\end{tabular} & $\begin{array}{r}7.8 \\
11.2 \\
6.4\end{array}$ & \begin{tabular}{|r|}
11.8 \\
17.8 \\
7.8 \\
\end{tabular} & \begin{tabular}{r|}
10.7 \\
11.2 \\
3.8
\end{tabular} & $\begin{array}{l}5.5 \\
6.0 \\
1.8\end{array}$ & $\begin{array}{l}4.3 \\
3.4 \\
2.0\end{array}$ & & & & & & & & $\begin{array}{l}\mathrm{H}=40 \mathrm{~km} \\
0,-10-30 \mathrm{~km} \\
\text { Mouth of } \\
\text { Tome River }\end{array}$ \\
\hline 2 & $\begin{array}{c}7.23 .1971 \\
\text { M- } 5.3 \\
\text { Eat orn } \\
\text { Yamenashitken }\end{array}$ & $\begin{array}{l}\text { NS } \\
\text { EW } \\
\text { UD }\end{array}$ & $\begin{array}{l}5.6 \\
8.6 \\
2.2\end{array}$ & $\begin{array}{l}2.5 \\
2.6 \\
1.2\end{array}$ & $\left.\begin{array}{l}2.7 \\
4.3 \\
1.3\end{array}\right]$ & $\mid \begin{array}{r}16.8 \\
12.3 \\
5.7\end{array}$ & $\begin{array}{r}13.3 \\
11.8 \\
3.3\end{array}$ & $\begin{array}{l}5.6 \\
5.0 \\
3.0\end{array}$ & $\begin{array}{l}6.4 \\
3.5 \\
2.6\end{array}$ & $\begin{array}{r}12.4 \\
6.7 \\
5.4\end{array}$ & $\begin{array}{l}5.3 \\
5.5 \\
4.1\end{array}$ & $\begin{array}{l}4.9 \\
8.5 \\
3.4\end{array}$ & & & & & $\begin{array}{l}\mathrm{H}=40 \mathrm{~km} \\
\Delta:=60 \sim 80 \mathrm{~km}\end{array}$ \\
\hline 3 & $\begin{array}{l}2.29 .1972 \\
\text { EOFF } \\
\text { Hechijo }\end{array}$ & $\begin{array}{l}\text { NS } \\
\text { EW } \\
\text { UD }\end{array}$ & $\begin{array}{l}46.1 \\
51.6 \\
17.2 \\
\end{array}$ & \begin{tabular}{l|}
32.3 \\
23.6 \\
10.9 \\
\end{tabular} & $\begin{array}{l}18.6 \\
21.6 \\
13.3 \\
\end{array}$ & & & & & $\begin{array}{r}10.3 \\
8.6 \\
6.0 \\
\end{array}$ & $\begin{array}{l}13.1 \\
14.9 \\
11.3\end{array}$ & $\begin{array}{l}12.2 \\
14.6 \\
10.4\end{array}$ & & & & & $\begin{array}{l}\mathrm{H}-70 \mathrm{~km} \\
\Delta=300 \mathrm{~km}\end{array}$ \\
\hline 4 & $\begin{array}{c}10.18,1972 \\
M-5.1 \\
\text { Northern } \\
\text { Chibe-ken }\end{array}$ & $\begin{array}{l}\text { NS } \\
\text { EW } \\
\text { UD }\end{array}$ & $\begin{array}{l}6.4 \\
8.0 \\
2.8\end{array}$ & \begin{tabular}{l|}
3.5 \\
3.3 \\
1.3
\end{tabular} & $\begin{array}{l}2.1 \\
2.5 \\
1.2 \\
\end{array}$ & \begin{tabular}{r|}
6.5 \\
12.0 \\
4.2 \\
\end{tabular} & $\begin{array}{l}5.8 \\
9.6 \\
2.8\end{array}$ & \begin{tabular}{l|}
3.7 \\
2.1 \\
1.6
\end{tabular} & $\begin{array}{l}3.1 \\
3.6 \\
1.1\end{array}$ & $\begin{array}{r}6.1 \\
17.2 \\
1.0\end{array}$ & $\begin{array}{l}4.6 \\
3.0 \\
2.1\end{array}$ & $\begin{array}{l}3.1 \\
3.5 \\
1.8\end{array}$ & & & & & $\begin{array}{l}\mathrm{H}-60 \mathrm{~km} \\
\Delta-50-70 \mathrm{~km}\end{array}$ \\
\hline 5 & $\begin{array}{l}\text { 11. } 6.1972 \\
s b_{b}-5.1 \\
\text { bar aki -ken }\end{array}$ & $\begin{array}{l}\text { NS } \\
\text { EW } \\
\text { UD }\end{array}$ & $\begin{array}{l}2.8 \\
3.2 \\
1.8\end{array}$ & $\begin{array}{l}1.6 \\
1.4 \\
0.9\end{array}$ & $\begin{array}{l}0.8 \\
1.4 \\
0.9\end{array}$ & \begin{tabular}{l|}
3.3 \\
8.1 \\
2.2
\end{tabular} & $\begin{array}{l}3.2 \\
6.3 \\
1.4\end{array}$ & \begin{tabular}{l|}
2.0 \\
2.5 \\
0.9
\end{tabular} & $\begin{array}{l}1.8 \\
1.6 \\
0.9\end{array}$ & & & & & & & & $\begin{array}{l}H=10 \mathrm{~km} \\
\Delta:-60-90 \mathrm{~km}\end{array}$ \\
\hline 6 & $\begin{array}{l}12.4 .1972 \\
N=7.2 \\
E \text { Orf } \\
\text { Hechijo }\end{array}$ & $\begin{array}{l}\text { NS } \\
\text { EW } \\
\text { UD }\end{array}$ & & & & $\begin{array}{c}20.0 \\
15.6 \\
4.1\end{array}$ & $\begin{array}{r}14.6 \\
11.3 \\
3.6\end{array}$ & $\begin{array}{l}7.4 \\
7.1 \\
3.0\end{array}$ & $\begin{array}{l}6.4 \\
4.7 \\
3.0\end{array}$ & $\begin{array}{l}6.5 \\
7.3 \\
-\end{array}$ & $\begin{array}{c}10.1 \\
10.6 \\
-\end{array}$ & $\begin{array}{c}10.4 \\
10.7 \\
-\end{array}$ & & & & & $\begin{array}{l}\mathrm{H}-50 \mathrm{~km} \\
\Delta-300-320 \mathrm{~km}\end{array}$ \\
\hline 7 & $\begin{array}{l}\text { 12. } 8.1972 \\
M=4.8 \\
\text { Nokyo the } \\
\text { Toky }\end{array}$ & $\begin{array}{l}\text { NS } \\
\text { EW } \\
\text { UD }\end{array}$ & $\begin{array}{r}12.3 \\
7.0 \\
4.0 \\
\end{array}$ & $\begin{array}{l}7.2 \\
3.6 \\
1.8\end{array}$ & $\begin{array}{l}3.2 \\
8.5 \\
2.1\end{array}$ & \begin{tabular}{r|}
10.1 \\
13.4 \\
3.7 \\
\end{tabular} & $\begin{array}{r}9.3 \\
10.4 \\
2.4\end{array}$ & \begin{tabular}{l|}
5.3 \\
4.2 \\
1.6
\end{tabular} & $\begin{array}{l}4.4 \\
3.3 \\
1.5\end{array}$ & $\begin{array}{r}8.3 \\
16.8 \\
6.1\end{array}$ & $\begin{array}{l}5.0 \\
5.9 \\
2.5\end{array}$ & $\begin{array}{l}4.2 \\
5.3 \\
2.5\end{array}$ & & & & & $\begin{array}{l}H=90 \mathrm{~km} \\
\Delta=20 \sim 40 \mathrm{~km}\end{array}$ \\
\hline B & $\begin{array}{c}3.27 .1973 \\
M-4.9 \\
\text { Tokgo Bay }\end{array}$ & $\begin{array}{l}\text { NS } \\
\text { EW } \\
\text { UD }\end{array}$ & $\begin{array}{r}47.5 \\
42.1 \\
7.1 \\
\end{array}$ & $\begin{array}{r}30.7 \\
12.3 \\
6.5 \\
\end{array}$ & $\begin{array}{r}7.4 \\
13.7 \\
5.8 \\
\end{array}$ & & & & & \begin{tabular}{r|}
18.6 \\
31.5 \\
8.5 \\
\end{tabular} & $\begin{array}{r}25.9 \\
26.7 \\
9.3\end{array}$ & $\mid \begin{array}{c}16.8 \\
- \\
5.4\end{array}$ & & & & & $\begin{array}{l}H=60 \mathrm{~km} \\
\Delta-20-40 \mathrm{~km}\end{array}$ \\
\hline 9 & $\begin{array}{c}12.22 .1973 \\
M-5.0 \\
\text { Southern } \\
\text { chibe-kon }\end{array}$ & $\begin{array}{l}\text { NS } \\
\text { EW } \\
\text { UD }\end{array}$ & $\begin{array}{r}10.5 \\
7.6 \\
3.4 \\
\end{array}$ & $\begin{array}{l}8.5 \\
4.3 \\
1.8\end{array}$ & $\begin{array}{l}2.6 \\
7.8 \\
2.3 \\
\end{array}$ & & & & & $\begin{array}{r}130 \\
18.4 \\
6.3\end{array}$ & $\begin{array}{l}6.4 \\
7.3 \\
3.0\end{array}$ & $\begin{array}{l}6.0 \\
7.4 \\
3.9\end{array}$ & & & & & $\begin{array}{l}\mathrm{H}=70 \mathrm{~km} \\
\triangle \mathrm{m} 50 \sim 55 \mathrm{~km}\end{array}$ \\
\hline 10 & $\begin{array}{c}\text { 5. } 9.1974 \\
\text { M- } 6.9 \\
\text { S Coent of } \\
\text { Ieu Pen. } \\
\end{array}$ & $\begin{array}{l}\text { NS } \\
\text { EW } \\
\text { UD }\end{array}$ & \begin{tabular}{|l|}
38.0 \\
40.6 \\
13.9 \\
\end{tabular} & \begin{tabular}{r|}
22.3 \\
26.4 \\
6.8 \\
\end{tabular} & \begin{tabular}{r|}
28.7 \\
13.7 \\
7.1 \\
\end{tabular} & & & & & $\begin{array}{l}30.0 \\
37.7 \\
12.5 \\
\end{array}$ & $\begin{array}{r}14.7 \\
17.7 \\
6.9 \\
\end{array}$ & $\begin{array}{r}11.5 \\
22.4 \\
5.5 \\
\end{array}$ & & & & & $\begin{array}{l}\mathrm{H}-10 \mathrm{~km} \\
\Delta=110 \mathrm{~N} 2 \mathrm{~km} \\
01 \mathrm{f} 1 \mathrm{zu} \\
\text { P.n. Eq. }\end{array}$ \\
\hline 11 & $\begin{array}{c}7.1974 \\
M-6.3 \\
\text { Of I I beraki } \\
\text {-ken }\end{array}$ & $\begin{array}{l}\text { NS } \\
\text { EW } \\
\text { UD }\end{array}$ & $\begin{array}{l}4.1 \\
3.3 \\
2.3\end{array}$ & $\begin{array}{l}2.4 \\
1.9 \\
1.7\end{array}$ & $\begin{array}{l}0.9 \\
2.0 \\
1.3\end{array}$ & $\begin{array}{l}4.2 \\
3.3 \\
1.5\end{array}$ & $\begin{array}{l}2.0 \\
0.7 \\
1.0\end{array}$ & \begin{tabular}{l|}
2.9 \\
1.3 \\
1.0
\end{tabular} & $\begin{array}{l}1.0 \\
1.7 \\
1.0\end{array}$ & $\begin{array}{l}3.5 \\
3.6 \\
2.0\end{array}$ & $\begin{array}{l}1.9 \\
1.9 \\
1.9\end{array}$ & $\begin{array}{l}1.5 \\
2.0 \\
1.2\end{array}$ & & & & & $\begin{array}{l}H=40 \mathrm{~km} \\
\Delta-160 \sim 190\end{array}$ \\
\hline 12 & $\begin{array}{c}8.1974 \\
\text { MW - } 5.8 \\
\text { Iboraki-ken }\end{array}$ & $\begin{array}{l}\text { NS } \\
\text { EW } \\
\text { UD }\end{array}$ & & & & $\begin{array}{r}13.6 \\
12.9 \\
5.8\end{array}$ & $\begin{array}{r}10.6 \\
7.7 \\
3.1 \\
\end{array}$ & \begin{tabular}{l|}
6.5 \\
5.5 \\
2.0
\end{tabular} & $\begin{array}{l}5.1 \\
4.4 \\
1.9\end{array}$ & $\begin{array}{r}12.5 \\
15.0 \\
4.5 \\
\end{array}$ & $\begin{array}{l}6.5 \\
7.1 \\
4.5\end{array}$ & $\begin{array}{l}4.9 \\
6.5 \\
3.2\end{array}$ & $\begin{array}{r}12.1 \\
8.2 \\
10.7\end{array}$ & \begin{tabular}{l|}
7.1 \\
6.0 \\
4.7
\end{tabular} & $\begin{array}{c}8.5 \\
10.8 \\
- \\
\end{array}$ & \begin{tabular}{l|}
6.2 \\
4.8 \\
3.4 \\
\end{tabular} & $\begin{array}{l}\mathrm{H}-50 \mathrm{~km} \\
\Delta \sim 60 \sim 90 \mathrm{~km}\end{array}$ \\
\hline 13 & $\begin{array}{l}9.27,1971 \\
M=6.5 \\
\text { SE Ori } \\
\text { BOBO pen }\end{array}$ & $\begin{array}{l}\text { NS } \\
\text { EW } \\
\text { UD }\end{array}$ & $\begin{array}{r}11.8 \\
10.2 \\
6.9 \\
\end{array}$ & $\begin{array}{l}7.0 \\
7.1 \\
4.0\end{array}$ & $\begin{array}{l}5.0 \\
5.9 \\
3.0\end{array}$ & $\begin{array}{l}7.0 \\
5.5 \\
3.1\end{array}$ & $\begin{array}{l}5.9 \\
5.0 \\
2.0\end{array}$ & \begin{tabular}{l|}
3.7 \\
3.3 \\
1.3
\end{tabular} & $\begin{array}{l}3.1 \\
1.9 \\
1.3\end{array}$ & & & & $\begin{array}{l}4.7 \\
5.9 \\
4.5\end{array}$ & $\begin{array}{l}5.0 \\
3.9 \\
2.5\end{array}$ & $\begin{array}{l}5.0 \\
5.5 \\
2.3\end{array}$ & \begin{tabular}{l|}
2.9 \\
3.2 \\
1.6
\end{tabular} & $\begin{array}{l}H-40 \mathrm{~km} \\
\Delta=240 \mathrm{~km}\end{array}$ \\
\hline 14 & $\begin{array}{c}1116.1971 \\
\text { M-61 } \\
\text { Neer Choshi } \\
\text { Chibe-ken }\end{array}$ & $\begin{array}{l}\text { NS } \\
\text { EW } \\
\text { UD }\end{array}$ & & & & $\begin{array}{l}4.8 \\
4.8 \\
1.7\end{array}$ & $\begin{array}{l}4.0 \\
2.6 \\
1.2\end{array}$ & \begin{tabular}{l|}
3.0 \\
2.2 \\
1.6
\end{tabular} & $\begin{array}{l}2.8 \\
1.7 \\
1.2\end{array}$ & & & & $\begin{array}{l}5.4 \\
3.6 \\
3.1 \\
\end{array}$ & \begin{tabular}{l|}
3.4 \\
4.2 \\
2.8 \\
\end{tabular} & $\begin{array}{l}2.9 \\
3.3 \\
2.9 \\
\end{array}$ & $\begin{array}{l}1.8 \\
1.9 \\
1.4\end{array}$ & $\begin{array}{l}\mathrm{H}=40 \mathrm{~km} \\
\Delta \quad 140 \mathrm{~km}\end{array}$ \\
\hline 15 & $\begin{array}{c}13.30 .1974 \\
M=7.5-7.75 \\
\text { Near Tori } \\
\text { shrm }\end{array}$ & $\begin{array}{l}\text { NS } \\
\text { EW } \\
\text { UD }\end{array}$ & $\begin{array}{r}116 \\
8.5 \\
4.7 \\
\end{array}$ & $\begin{array}{l}8.5 \\
5.8 \\
3.1 \\
\end{array}$ & $\begin{array}{l}4.0 \\
4.5 \\
2.8 \\
\end{array}$ & $\begin{array}{l}6.2 \\
5.3 \\
2.3 \\
\end{array}$ & $\begin{array}{l}7.0 \\
5.0 \\
1.7 \\
\end{array}$ & $\begin{array}{l}2.5 \\
2.9 \\
1.3 \\
\end{array}$ & $\begin{array}{l}2.8 \\
2.2 \\
1.1 \\
\end{array}$ & & & & $\begin{array}{l}6.2 \\
6.2 \\
3.7 \\
\end{array}$ & $\begin{array}{l}3.2 \\
3.4 \\
2.2 \\
\end{array}$ & $\begin{array}{l}5.6 \\
6.8 \\
2.4 \\
\end{array}$ & $\begin{array}{l}1.2 \\
3.6 \\
1.5 \\
\end{array}$ & $\begin{array}{l}\mathrm{H}-350 \mathrm{~km} \\
\Delta \leftrightharpoons 550 \mathrm{~km}\end{array}$ \\
\hline 16 & $\begin{array}{c}2.8 .1975 \\
M-54 \\
\text { Northern } \\
\text { Chiba-ken }\end{array}$ & $\begin{array}{l}\text { NS } \\
\text { EW } \\
\text { UD }\end{array}$ & & & & $\begin{array}{r}14.2 \\
18.9 \\
5.6\end{array}$ & $\begin{array}{r}9.3 \\
16.6 \\
311\end{array}$ & $\begin{array}{l}4.8 \\
7.5 \\
2.6\end{array}$ & $\begin{array}{l}4.2 \\
5.5 \\
2.0\end{array}$ & & & & & & & & $\begin{array}{l}\mathrm{H}=50 \mathrm{~km} \\
\Delta \leftrightharpoons 50 \mathrm{~km}\end{array}$ \\
\hline
\end{tabular}


- Although the acceleration values are smaller at deeper layers, frequency characteristics of underground seismic motions are close to those of the surface motions.

- The characteristics of earthquake ground motions appear to be influenced by seismic conditions, such as magnitudes of earthquakes, epicentral distances, etc., as well as soil conditions at the site.

The damage to underground tunnels and mines does not have a large data base, especially with respect to measured displacement. However, the relation between velocity (and thus distance for $M=5,6$, and 6.5 ) and damage level has been summarized by Rozen. ${ }^{2}$ Strong tensile and some radial cracking was noted at surface velocities of $152 \mathrm{~cm} / \mathrm{sec}$ which would occur at distances of about $7-8 \mathrm{~km}$ during a magnitude 6.5 earthquake. Even at these leve1s seismic damage would be negligible in competent rock (Figure 15 ). ${ }^{2}$

The data for measured displacements as a function of depth are summarized in Figure 16. Surface displacements range from at least 1 to $10 \mathrm{~m}$, depending on geology, magnitude, etc., but decrease markedly with depth. Displacements of $\leq 25 \mathrm{~cm}$ have been measured at 100-m depth in in situ rock masses. Displacements of $<7 \mathrm{~m}$ have been noted along pre-existing faults. The data base below $500 \mathrm{~m}$ is almost negligible. The one data point from South Africa needs more detailed study of displacement, rock type, and local tectonic environment.

Wells

The damage to water and oil wells has been documented in a limited number of reports. Failure of water wells is primarily due to sanding or silting; however, in some instances, there has been crushing, bending, or shearing of the casing due to differential movement of the surrounding rock. The latter mode of failure has also affected some oil wells. The damage to wells appears to be more of a near-surface phenomenon than one at depths of $>100 \mathrm{~m}$, except where the well crosses a fault.

The damage to wells during the earthquake on July 21, 1952 in Kern County, California has been summarized by Steinbrugge and Moran. ${ }^{8}$ Surveys were made of the oil and gas fields in the area by the oil companies almost immediately after the earthquake; however, detailed surveys were not made until 10 days after the earthquake when noticeable changes began to occur in the operations of the fields. Variations in production were pronounced in the Tejon Ranch, Kern River, and Frustvale fields which trend approximately north-south from about Bakersfield to Wheeler Ridge, California. The greatest amount of damage to subsurface equipment occurred in the Tejon Ranch field where several shallow 


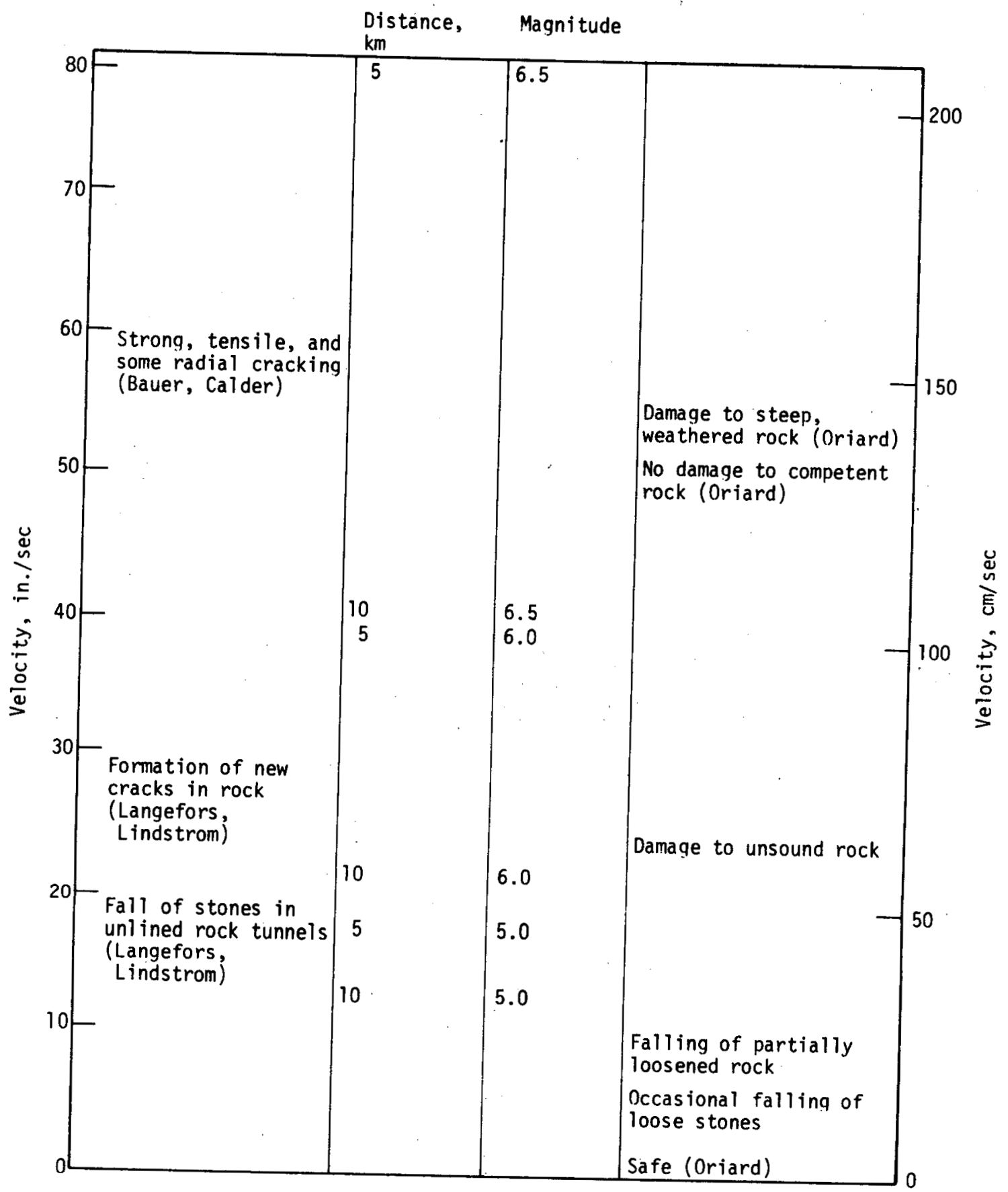

FIGURE 15. Summary of Damage Level $\mathrm{s}^{2}$ 
wells were found to have the casing collapsed or tubing kinked. In 6 wells, it was necessary to redrill the well. In the Kern River field, 150 wells were found to be sanded up as a result of the earthquake, but no cases of damage to the casings were found. The investigations revealed that the greatest effects of the earthquake were predominantly in the fields producing from soft unconsolidated formations.

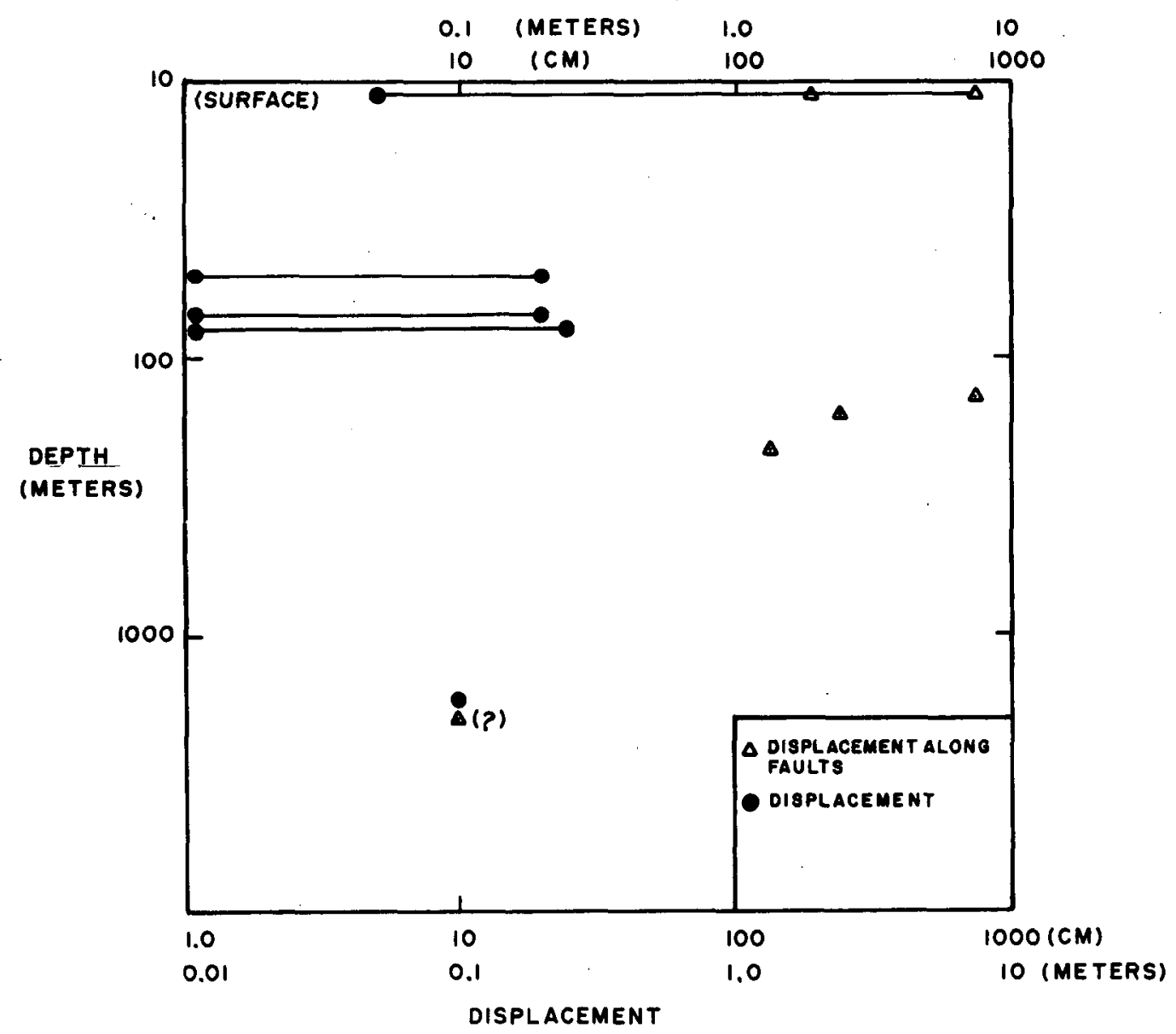

FIGURE 16. Measured: Range of Displacements as a Function of Depth 
The U. S. G. S. documented the effects of the Alaska earthquake, March 27, 1964, on wells throughout most of Alaska and the changes in water levels noted in the lower 48 . Waller er,47 summarized the damage to wells in Alaska as mainly due to sanding or silting of the well or differential movement of casing caused by movement of the surrounding rock. Table 3 lists those wells reported by Waller as damaged and pertinent details on each. A detailed tabulation of data, mainly from the Anchorage areas, summarized from Waller is presented in Appendix B. Three city wells were damaged in Anchorage and possibly one private well. The three city wells were all damaged by movement resulting in bent or broken casing. One of the damaged wells was in artificial fill where differential movement bent the casing; however, the casing was straightened and the well was put back into service. The other two city wells were in or near the Turnagain slide area and were destroyed by the lateral movement. Three city wells in Seward were damaged and rendered useless by ground movement and fissuring; in Valdez, one well had the casing sheared at a threaded joint $4.7 \mathrm{~m}$ below ground surface. Near Yakataga, one abandoned exploratory oil well was sheared off. No damage was reported to any of the oil and gas wells in and along Cook Inlet.

After the earthquake $(M=5.5)$ in Southern Illinois on November 9, 1968, the Illinois State Geological Survey made a survey in the area; the results were reported by Heigold. ${ }^{48}$ One old plugged gas well suffered cracks in the casing apparently as a result of the earthquake, and a few well structures in the immediate vicinity of the epicenter were damaged.

Some damage to wells occurred during the earthquake on February 9, 1971, in San Fernando, California. 49,50 Minor damage was reported to a few oil wells in the area, and all seven wells which supplied water to the city of San Fernando suffered damage during the earthquake causing a severe water supply problem.

Oil wells in the greater Los Angeles area which cross faults have had the casing ruptured by movement along the faults; however, it is uncertain if the movement is creep of a tectonic origin or settlement due to subsidence.

Damage to we1ls in the San Joaquin Valley due to compaction of sediments caused by the withdrawal of ground water is relatively common, but this damage is due to aseimic causes.

A reduction in peak acceleration of a factor of 5 , from $0.05 \mathrm{~g}$ at the surface to $0.01 \mathrm{~g}$ at the depth of $165 \mathrm{~m}$ in a borehole, was noted during the Briones ${ }^{38}$ earthquake $\left(M_{L}=4.5\right) .{ }^{51}$ The borehole was located in the Hayward fault in Berkeley, California. 
TABLE 3

Wells Damaged by Alaska Earthquake of March $1964^{46}$

Location ${ }^{\alpha}$ Depth, Diameter, Earthquake Effects

$m \quad m$

Anchorage $143.2 \quad 0.2032$ Casing bent and broken. East of the downtown section near Mountain View. Generally in clay with a few lenses of sand and gravel.

Anchorage $\quad 23.5 \quad 0.1524$

Casing damaged (?). Private well, extent of damage unknown, new well drilled. On southern edge of town. In gravelly clay.

Anchorage $151.5 \quad 0.2032$

Casing severely damaged, well destroyed by movement (slide) of soil. In the Turnagain Heights area. In clay with several thick sand layers and a few gravelly sands.

Anchorage $\quad 31.1 \quad 0.152$

Casing destroyed, probably by movement of the surrounding material. Near the Turnagain Heights area. In clay with some gravelly clay and sand near bottom.

Valdez

$7.3-$

Casing bent seaward by 1 and movement and sheared at threaded joint $4.7 \mathrm{~m}$ below ground surface. In outwash plane of glacier.

Seward $\quad 30.5$

Damaged; casing bent by movement of rock.

Seward $\quad 30.5$

Damaged by movement of a portion of the alluvial fan; casing bent.

Survived quake; about one month later pump turbine jammed because of slow ground movement or settlement.

a. In a survey of 106 wells in Anchorage, Valdez, and Seward, these were the only wells damaged, although others commonly showed some effect such as a change in water level or the water becoming muddy for a period. 
In general, the performance of wells during earthquakes is quite good, with the major damage resulting from bending, crushing, or shearing of the casing due to differential movement of the surrounding rock. In general, the major damage appears to be to shallow wells that are in unconsolidated sediments and near the surface. There is very little damage to wells deeper than about $100 \mathrm{~m}$ except where the well cross a fault plane along which movement occurs.

\section{Nuclear Events as Eàrthquake Simulators}

The use of nuclear events as equivalent earthquake sources has been discussed by a number of people. $11,52,53$ The data from nuclear events can be useful in assessing the potential damage from earthquakes to underground facilities. The resulting velocities, accelerations, and displacements from nuclear events have been monitored carefully because of their importance to defense-related issues. In many cases, the data are obtained at conditions that would be near the hypocenter of the earthquake and thus more severe than would be anticipated from any earthquake affecting a nuclear waste repository. It should be possible, however, to place certain bounds on the maximum accelerations, velocities, and displacements expected from comparable earthquakes. This would be helpful in establishing damage criteria for potential earthquake damage to waste repositories. It is again emphasized that this report is not meant to arrive at any damage criteria for a repository, but to gather the available data and begin to assess damage criteria that might ultimately be used for the seismic risk assessment of nuclear waste repositories.

At the outset, it is important to compare nuclear events with earthquakes to determine the scaling relationships between the two. An important point to make is that a comparable magnitude only indicates that $P$-wave signals from both earthquakes and explosions are of equal strength. However, nuclear explosions tend to produce much weaker surface waves than do earthquakes of comparable body-wave magnitude (Figure 17). As a consequence, the surface wave energy associated with an earthquake of a given bodywave magnitude is on the order of ten times that of an explosion of an equal body-wave magnitude. ${ }^{11}$ Therefore, a magnitude 5 explosion does not have the same potential for causing ground motion damage at the surface, as does a magnitude 5 earthquake. Table 4 lists several nuclear events of interest. Figure $18^{11}$ gives the body-wave magnitude as a function of yield for explosions in various rock types. Events of interest are in salt (GNOME, SALMON), granite (PILEDRIVER, HARDHAT, and SHOAL), andesite (LONGSHOT, CANNIKIN, MILROW), and basalt (DANNYBOY). 


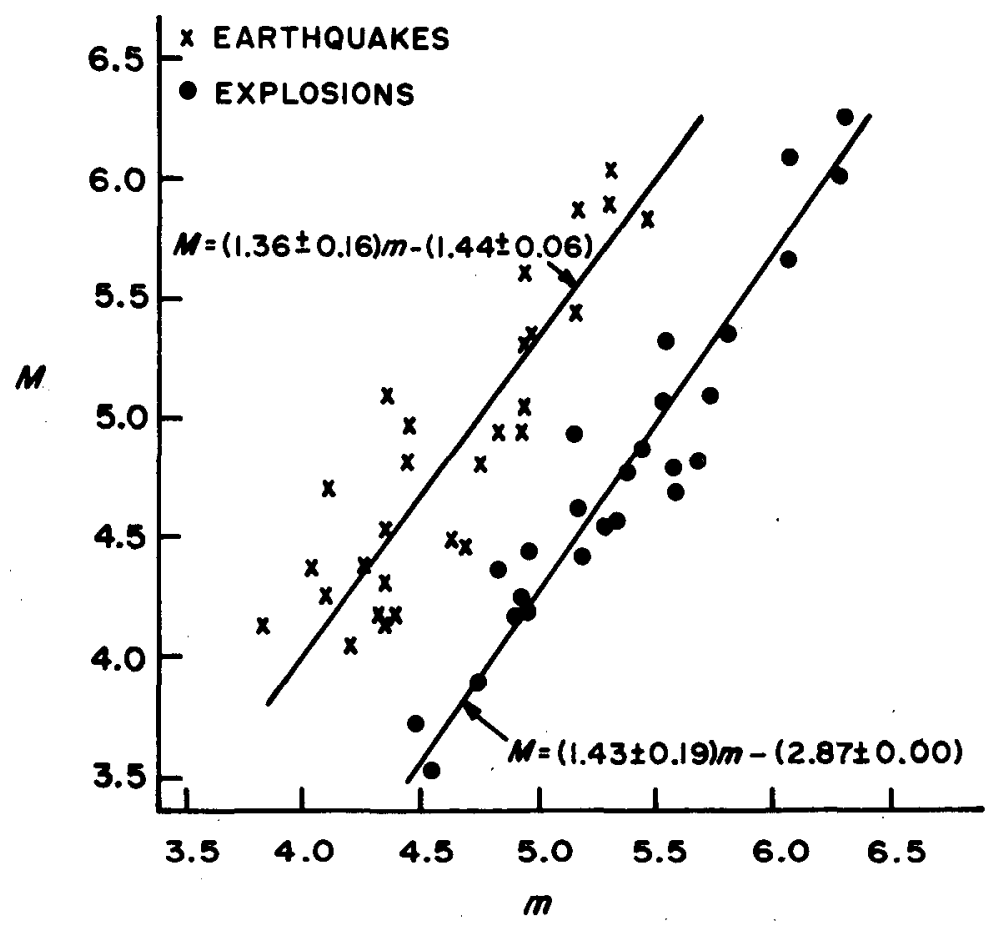

FIGURE 17. Mean Surface-Wave Magnitude (M) Versus Body-Wave Magnitude $(m)$ for 28 Earthquakes and 26 Nuclear Explosions in Southwestern North America, as determined by Canadian Measurements ${ }^{11}$

TABLE 4

Data from Nuclear Events

$\begin{array}{lllcl}\text { Event } & \text { Region } & \text { Medium } & \begin{array}{l}\text { Nominal } \\ \text { Yield, }\end{array} & \text { Magnitude } \\ \text { PILEDRIVER } & \text { NTS Area } 15 & \text { Granite } & 61 & 5.6 \\ \text { HARDHAT } & \text { NTS Area } 15 & \text { Granite } & 5.9 & 4.2 \\ \text { SHOAL } & \text { Fallon, NV } & \text { Granite } & 13 & 4.7 \\ \text { GREELEY } & \text { NTS Pahute Mesa } & \text { Tuff } & 1030 & 6.0 \\ \text { HALF BEAK } & \text { NTS Pahute Mesa } & \text { Rhyolite } & 365 & 6.0 \\ \text { BOXCAR } & \text { NTS Pahute Mesa } & \text { Rhyolite } & 1200 & 6.3 \\ \text { SEDAN } & \text { NTS Yucca Flat } & \text { Alluvium } & 100 & 4.2 \\ \text { LONGSHOT } & \text { Amchitak, AK } & \text { Andesite } & 81 & 5.9 \\ \text { MILROW } & \text { Amchitak, AK } & \text { Andesite } & 1200 & 6.1 \\ \text { CANNIKIN } & \text { Amchitak, AK } & \text { Andesite } & 5000 & 6.8-7.0 \\ \text { RULISON } & \text { Grand Valley, CO } & \text { SS.8 Shale } & 40 & \\ \text { SALMON } & \text { Hattiesburg, MI } & \text { Salt } & 5.0 & \\ \text { GNOME } & \text { Carlsbad, NM } & \text { Salt } & 3.1 & \end{array}$




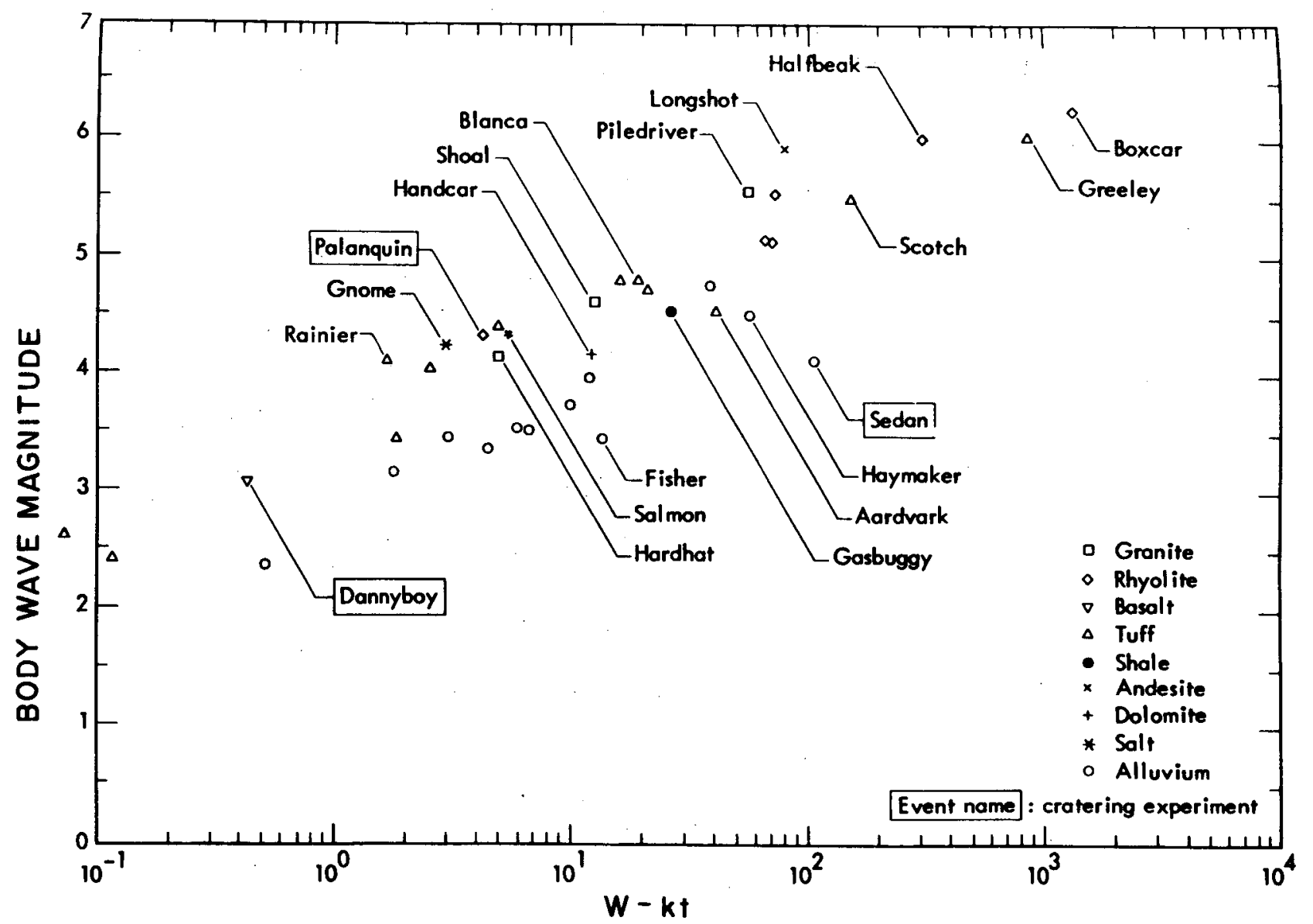

FIGURE 18. Body-Wave Magnitude Versus Explosion Yield and Rock Type $^{11}$ 
It will therefore be necessary to compare explosions and earthquakes based on criteria such as accelerations and displacements. One method of doing this is to plot the pseudo-relative velocity (PSRV) curves for various magnitude explosions and relate them to the PSRV curves from earthquakes at equivalent distances. PSRV curves for nuclear events are shown in Figure 19 for the range of 1 to 1000 kilotons $(k t) .{ }^{11}$ R. Simonson (Terra Tek) compared the response spectrum for a megaton (Mt) shot at a scaled depth of $\sim 1991 \mathrm{~m}$ with the $1940 \mathrm{E} 1$ Centro earthquake $(M=7.1)$ response spectrum (Figure 20). The results from the earthquake are similar to the BOXCAR event acceleration curve for $0.33 \mathrm{~g}$ maximum acceleration up to one-second period. Beyond one second, the acceleration is lower for the explosion. The BOXCAR acceleration curve is data taken $12.6 \mathrm{~km}$ from ground zero.

Figure 21 shows the PSRV response of the north-south component from the 1940 E1 Centro earthquake and the north-south component from Las Vegas for the BOXCAR event. ${ }^{54}$ The spectral plot is used to estimate damage prediction, and the threshold evaluation scale to analyze buildings and the effects of building damage from ground motion. The BOXCAR event had a body-wave magnitude of $\sim 6.5$. The BOXCAR event showed much lower acceleration, velocity, and displacement than did the E1 Centro north-south. The spectral response in terms of velocities, accelerations, and displacements is also shown for the BOXCAR event (Figure 22).54

Direct measurement from large explosions in the Alaskan peninsula volcanic rock (andesite) yields significant data for nearfield measurements of accelerations, velocity, and displacement. ${ }^{9}$ Measurements at the surface are important in assessing the role of pre-existing discontinuities in the resulting permanent displacements along faults in the neighborhood of explosions. These can be compared with the acceleration, velocity, and displacement measurements downhole. The problem of course, with the downhole measurements is that they are in the near-field region in an area of extremely high accelerations, far greater than those that would be expected in the repository unless the earthquake was directly at the repository. These however, will be important upper bounds for the trends of resulting accelerations and displacements that might occur.

The three events of interest are LONGSHOT, MILROW, and CANNIKIN whose event statistics are given in Table $5.9^{9}$ Peak yalues of acceleration, peak velocity, and displacement from both subsurface and surface stations are shown in Tables 6 and 7. Of particular interest are the vertical scaled acceleration, velocity, and displacement observed at MILROW and CANNIKIN. Even though subsurface motion data are also in the very high acceleration range, the peak and residual displacement values associated with these near-field distances from the event are of interest. 


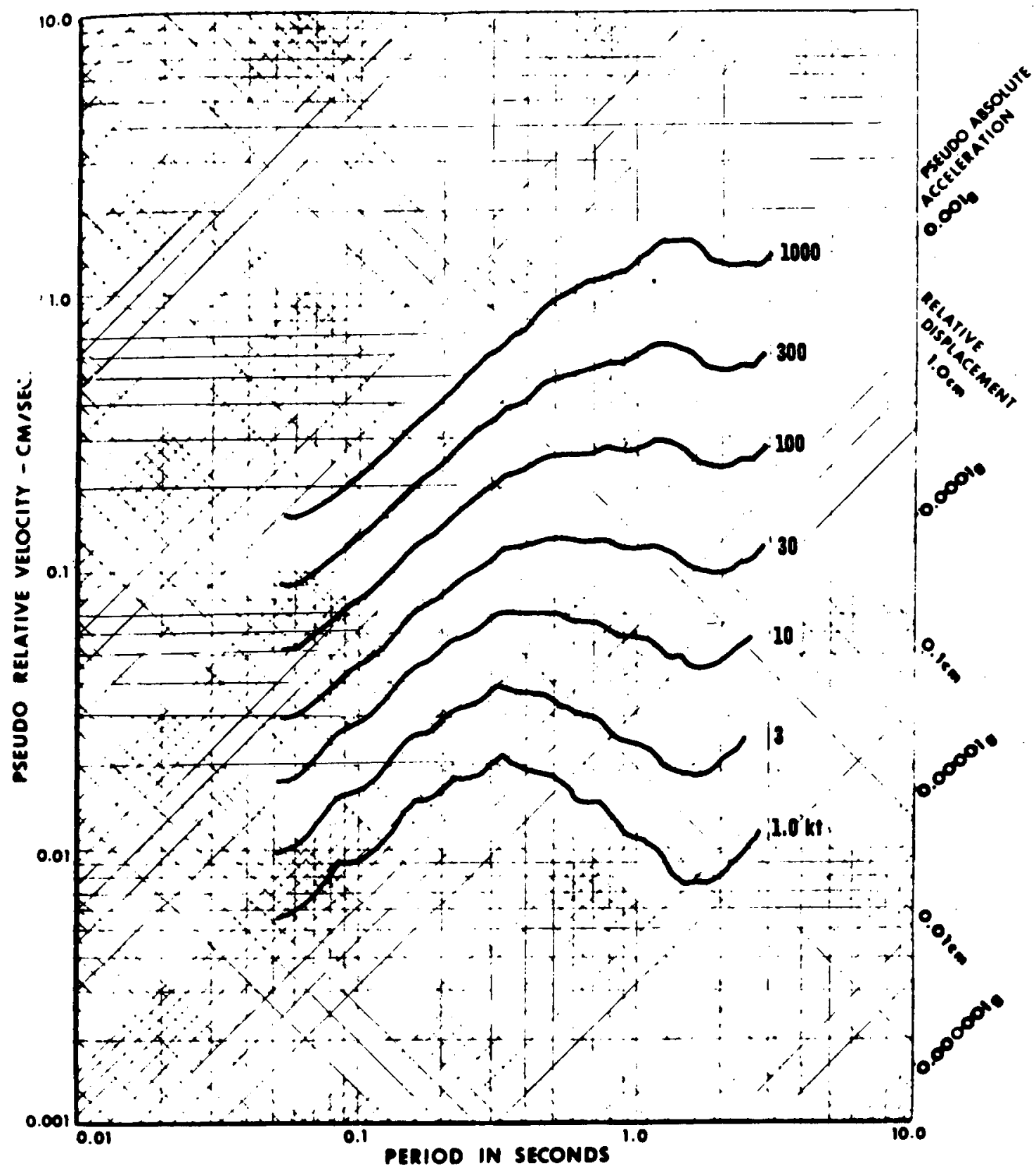

FIGURE 19. A Family of Predicted Mean Pseudo-Relative Response Velocity Curves for Seven Yields with 5\% Damping at a Distance of $100 \mathrm{~km}^{11}$ 


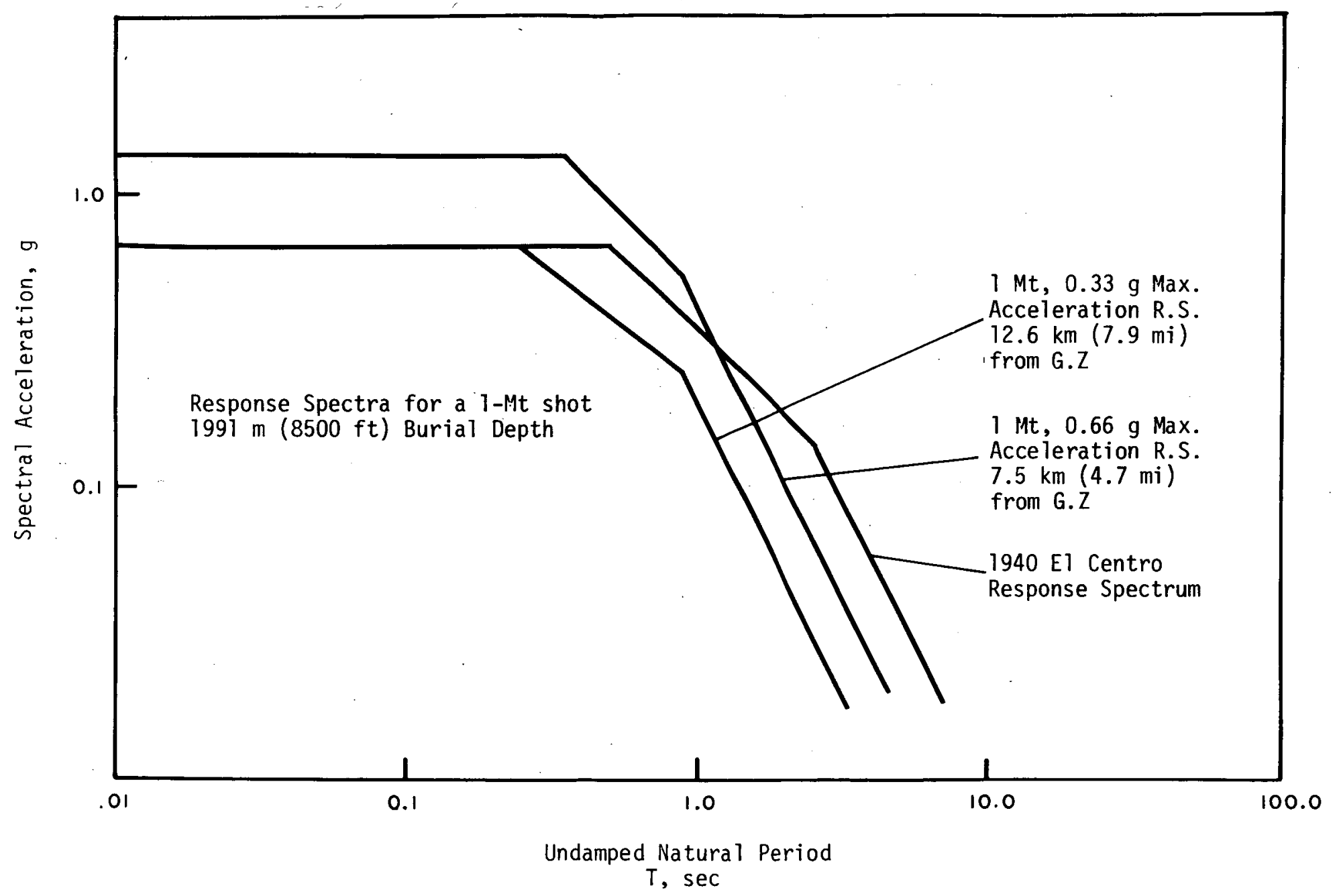

FIGURE 20. Acceleration as a Function of Period for the 1940 El Centro Earthquake and a Buried 1-Mt Nuclear Event ${ }^{58}$ 


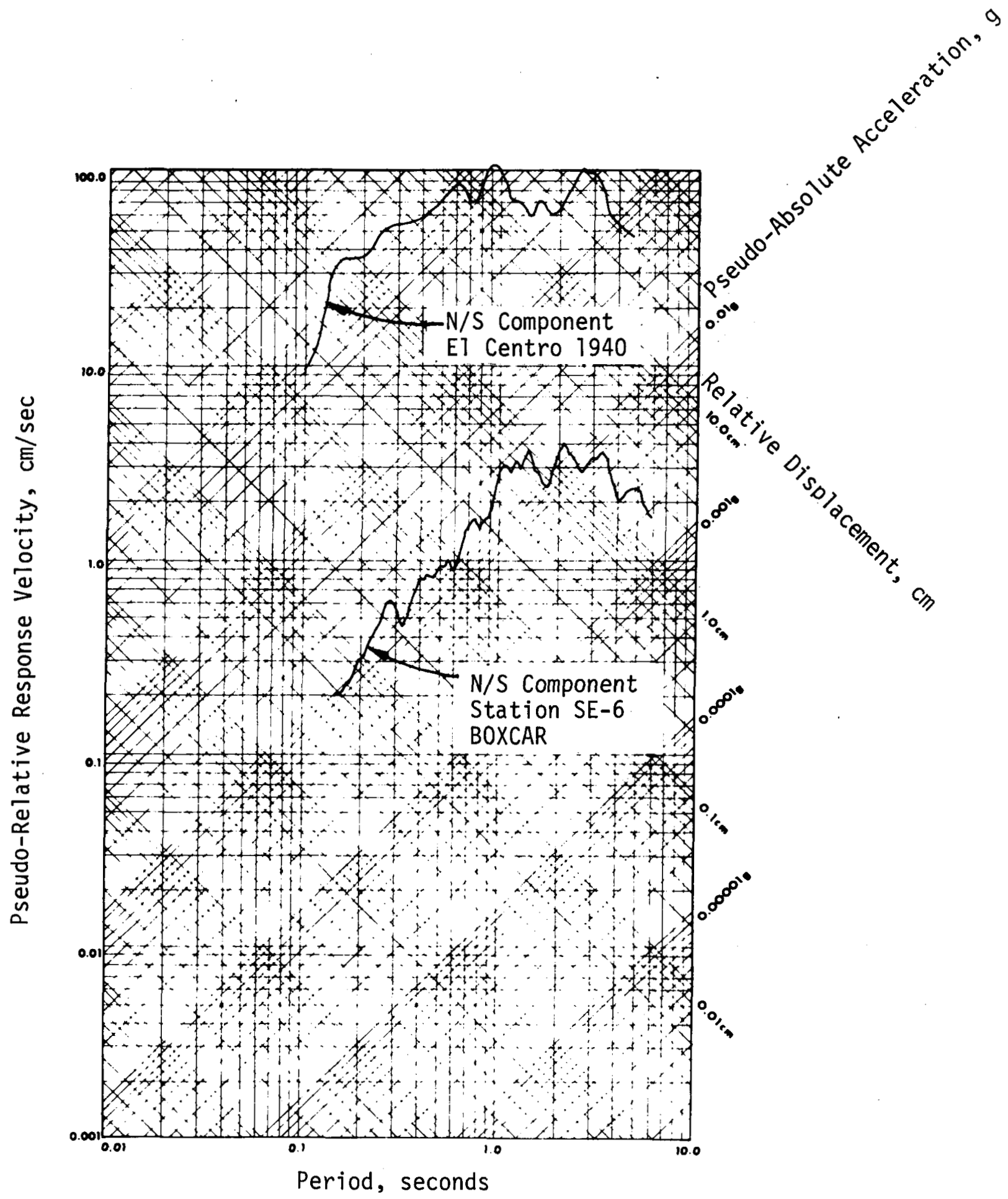

FIGURE 21. Pseudo-Relative Response Velocity Versus Damped Spectral Response ${ }^{54}$ 


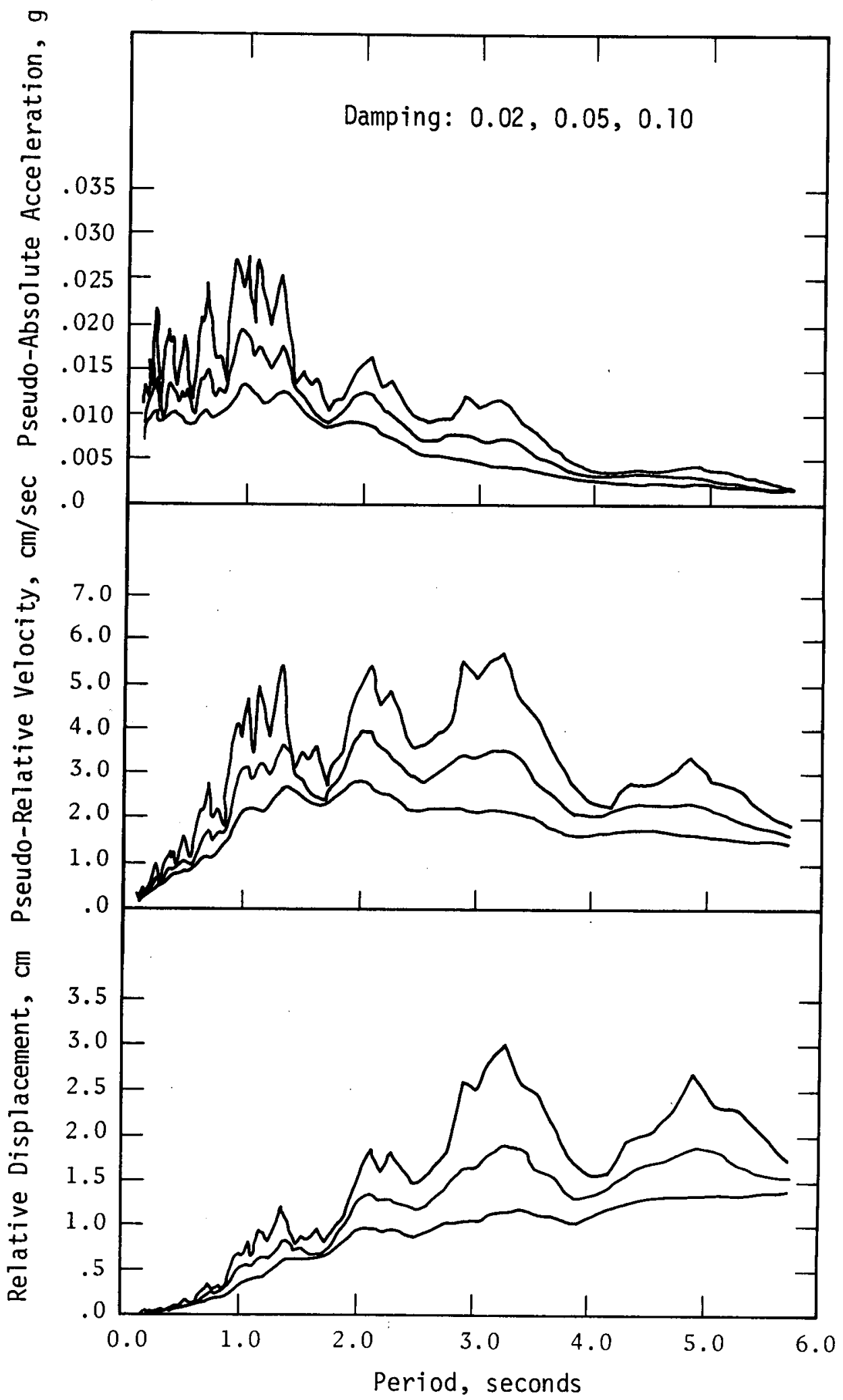

FIGURE 22. Spectral Response to Ground Motion at Station SE-G, N/S Component, Las Vegas, Event BOXCAR $(L-7)^{54}$ 
TABLE 5

Nuclear Event Statistics for LONGSHOT, MILROW, and CANNIKIN ${ }^{9}$

$\begin{array}{llll}\text { Event } & \text { LONGSHOT } & \text { MILROW } & \text { CANNIKIN } \\ \text { Date } & 10 / 29 / 65 & 10 / 2 / 69 & 11 / 6 / 71 \\ \text { Depth, meters } & 701 & 1219 & 1791 \\ \text { Rock } & \text { Volcanic Breccia } & \text { Pillow Lava } & \text { Pillow Lava } \\ \text { Yield, kilotons } & 81 & \sim 1000 & <5000\end{array}$

TABLE 6

MILROW and CANNIKIN Subsurface Motion Data ${ }^{9}$

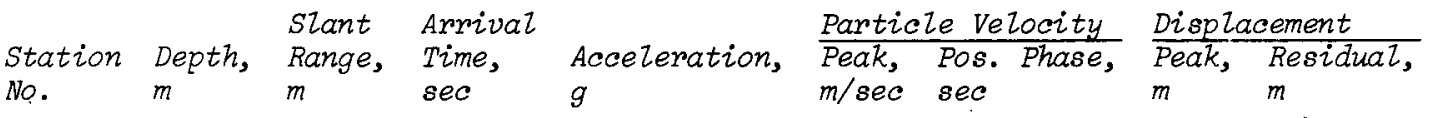

\section{MILROW}

$\begin{array}{rrrrr}\text { I- } 1-20 & 609.6 & 616.3 & 0.1465 & 67.3 \\ \text { I- } 1-25 & 457.2 & 767.5 & 0.1372 & 36.1 \\ \text { I- }-30 & 304.8 & 919.0 & 0.2332 & 27.3 \\ \text { I- } 1-33 & 132.4 & 1071 & 0.2772 & 24.5 \\ \text { I- }-37 & 91.4 & 1131 & 0.2983 & 19.6 \\ \text { I- }-3-39 & 30.5 & 1192 & 0.3152 & 20.7\end{array}$

$11.3>0.073$

$8.35 \quad 1.38$

$9.57 \quad 2.05$

$5.03 \quad 1.32$

$6.71 \quad 1.04$

$8.90 \quad 1.03$

$18.6>0.20$

$18.3>0.17$

$14.6>0.45$

$6.1>0.57$

$5.8 \cdot>0.52$

$6.7>0.46$

$7.6>0.20$

$11.0 \quad 0.57$

$10.0 \quad 1.26$

$\begin{array}{ll}>6 & - \\ 3.53 & +2.6 \\ 4.65 & +4.7 \\ 2.59 & +1.7 \\ 3.68 & +1.4 \\ 4.93 & +1.7\end{array}$

CANNIKIN

$\begin{array}{rrrrr}\text { I- 30 } & 888 & 906.5 & 0.198 & 57 \\ \text { I-40 } & 623 & 1171 & 0.260 & 30 \\ \text { I-45 } & 470 & 1324 & 0.305 & 14 \\ \text { I-50 } & 316 & 1477 & 0.348 & 12 \\ \text { I-55 } & 162 & 1630 & 0.400 & 12 \\ \text { I-57 } & 90.8 & 1702 & 0.425 & 16 \\ \text { I-58 } & 60.0 & 1732 & 0.435 & 18 \\ \text { I-59 } & 30.8 & 1762 & 0.450 & 19\end{array}$


TABLE 7

MILROW Surface Motion Data9

\begin{tabular}{|c|c|c|c|c|c|c|c|c|c|c|}
\hline \multirow[b]{2}{*}{$\begin{array}{l}\text { Station } \\
\text { No. }\end{array}$} & \multirow[b]{2}{*}{ Component } & \multirow{2}{*}{\multicolumn{2}{|c|}{ Range, $m$}} & \multirow{2}{*}{$\begin{array}{l}\text { Arrival } \\
\text { Time, } \\
\text { sec }\end{array}$} & \multirow{2}{*}{\multicolumn{2}{|c|}{ Acceleration, $g^{\alpha}$}} & \multicolumn{2}{|c|}{ Particle Velocity, ${ }^{a}$} & \multirow[b]{2}{*}{$\begin{array}{l}\text { Negative, } \\
\mathrm{m} / \mathrm{sec}\end{array}$} & \multirow[b]{2}{*}{$\begin{array}{l}\text { Displacement, } \\
\text { sec }\end{array}$} \\
\hline & & & & & & & $\begin{array}{l}\text { Positive, } \\
\mathrm{m} / \mathrm{sec}\end{array}$ & $\begin{array}{l}\text { Pos. Phase, } \\
\text { sec }\end{array}$ & & \\
\hline \multirow[t]{3}{*}{ S-0 } & Vert. & 75.6 & 1220 & 0.328 & 35.5 & 10.3 & 8.44 & 1.1 & -6.83 & 4.32 \\
\hline & Rad. & & & - & 1.6 & 2.9 & $0.49^{\prime}$ & 1.9 & -0.70 & 0.61 \\
\hline & Tang. & & & - & - & - & 0.22 & - & -0.23 & 0.03 \\
\hline \multirow[t]{3}{*}{ S- 2} & Vert. & 572.7 & 1350 & 0.368 & 14.1 & 10.4 & 4.79 & 0.64 & -3.20 & 1.50 \\
\hline & Rad. & & & - & 2.5 & -7.8 & 0.91 & 1.1 & -1.07 & 0.64 \\
\hline & Tang. & & & - & 1.2 & 6.6 & 0.37 & - & -1.10 & 0.05 \\
\hline \multirow[t]{3}{*}{ S-4 } & Vert. & 1225 & 1733 & 0.471 & 6.9 & 28,2 & 3.29 & 0.47 & -3.23 & 0.79 \\
\hline & Rad. & ; & & - & 2.1 & 10.1 & 0.67 & 1.1 & -0.73 & 0.53 \\
\hline & Tang. & . & & - & - & - & 0.14 & - & -0.37 & -0.07 \\
\hline S-5 & Vert. & 1354 & 1792 & 0.482 & 5.8 & 8.4 & 4.24 & 0.36 & -3.75 & 0.81 \\
\hline SF- 6 & Vert. & 1837 & 2196 & 0.620 & 8.6 & 19.4 & 1.86 & 0.30 & -2.38 & 0.30 \\
\hline & Tang. & & & - & -0.9 & -3.9 & 0.34 & 0.70 & -0.34 & -0.13 \\
\hline \multirow[t]{2}{*}{$S F-7$} & Vert. & 2010 & 2350 & 0.628 & 2.7 & 20.5 & 1.22 & 0.26 & -2.26 & 0.18 \\
\hline & Tang. & & & - & 0.82 & -3.1 & 0.46 & 0.53 & -0.28 & -0.08 \\
\hline \multirow[t]{3}{*}{ S- 8} & Vert. & 2405 & 2697 & 0.722 & 3.2 & 6.2 & 1.83 & 0.24 & -1.80 & 0.23 \\
\hline & Rad. & & & - & 1.5 & 4.3 & 0.76 & 1.1 & -0.37 & 0.28 \\
\hline & Tang. & & & - & - & - & 0.46 & - & -0.49 & -0.11 \\
\hline \multirow[t]{2}{*}{ S- 11} & Vert. & 3491 & 3696 & 1.000 & - & - & 0.98 & 0.27 & -1.04 & 0.15 \\
\hline & Rad. & & & - & - & - & 0.43 & - & -0.55 & 0.22 \\
\hline \multirow[t]{3}{*}{ S- 17} & Vert. & 5199 & 5339 & 1.405 & 1.6 & 1.8 & 0.76 & 0.21 & -0.79 & 0.08 \\
\hline & Rad. & & & - & 0.73 & - & 0.43 & 0.34 & -0.26 & 0.08 \\
\hline & Tang. & & & - & - & - & 0.12 & - & -0.10 & 0.04 \\
\hline \multirow[t]{3}{*}{ S- 32} & Vert. & 9852 & 9930 & 2.401 & 0.25 & 0.16 & 0.21 & 0.22 & -0.25 & 0.02 \\
\hline & Rad. & & & & 0.19 & 0.30 & 0.14 & 0.34 & -0.18 & 0.02 \\
\hline & Tang. & & & & 0.03 & 0.10 & 0.05 & - & -0.05 & 0.01 \\
\hline
\end{tabular}

a. Positive motion is upward in vertical components, outward in radial components, and clockwise in tangential components. 
At distances of $\sim 1 \mathrm{~km}$, between 2.5 and $5 \mathrm{~m}$ of peak displacement was noted, but only $1.7 \mathrm{~m}$ or less of final residual displacement. These data are for accelerations on the order of $20 \mathrm{~g}^{\prime} \mathrm{s}$. CANNIKIN must be remembered as a very large 5000 kiloton nuclear weapon equivalent to an earthquake of a body-wave magnitude of $\sim 7$. MILROW was a smaller event with peak displacements of less than 2 meters at a kilometer range. The residual displacements were not measured. The scaled surface vertical displacement attenuation of the Alaskan event is shown in Figure $23 .{ }^{9}$ The vertical displacement scales as

$$
\delta_{\mathrm{v}} / \mathrm{W}^{1 / 3}=1.26 \times 10^{6}\left(\mathrm{R} / \mathrm{W}^{1 / 3}\right)^{-2.28 \pm 0.19}
$$

where

$$
\begin{aligned}
\delta_{\mathrm{V}} & =\text { vertical displacement }, \mathrm{cm} \\
\mathrm{R} & =\text { range, } \mathrm{m} \\
\mathrm{W} & =\text { charge weight }, \mathrm{kt}
\end{aligned}
$$

Motion along faults that were mapped prior to the MILROW event in Alaska indicates that a maximum of $30 \mathrm{~cm}$ of vertical displacement and $10 \mathrm{~cm}$ of strike slip displacement resulted from the event (Figure 24). ${ }^{9}$ The distance of the Rifle Range fault was $1.9 \mathrm{~km}$ from the MILROW surface ground zero and gives a good indication of what displacements are like at those ranges. Two faults northwest of the CANNIKIN site were bracketed at those ranges. Two stations were on the opposite side of Teal Creek fault $1.5 \mathrm{~km}$ from surface ground zero and indicated a surface fault motion of $0.3 \mathrm{~m}$ in the case of the Teal Creek fault strike slip displacement and a vertical displacement on the order of $1.0 \mathrm{~m}$. The differential motion across another fault at a distance of $3.0 \mathrm{~km}$ was $0.25 \mathrm{~m}$ strike slip displacement and the order of $0.2 \mathrm{~m}$ of vertical displacement. At these distances, accelerations are $\sim 50 \mathrm{~g}^{\prime} \mathrm{s}$, equivalent to being near the epicenter of a major earthquake. However, it is difficult to relate these data to the subsurface data.

Cooper ${ }^{54}$ summarized the velocity and stress data for nuclear events in hard rock and indicates that velocity generally falls off as

$$
\mathrm{U}_{\mathrm{v}}=1.6 \times 10^{4}\left(\mathrm{R} / \mathrm{w}^{1 / 3}\right)^{-1.6}
$$

for scaled radius (Figure 25). ${ }^{5}$ The Alaskan events are included in the data base. The data from softer rock (tuff) fall below the scatter band for hard rock. 


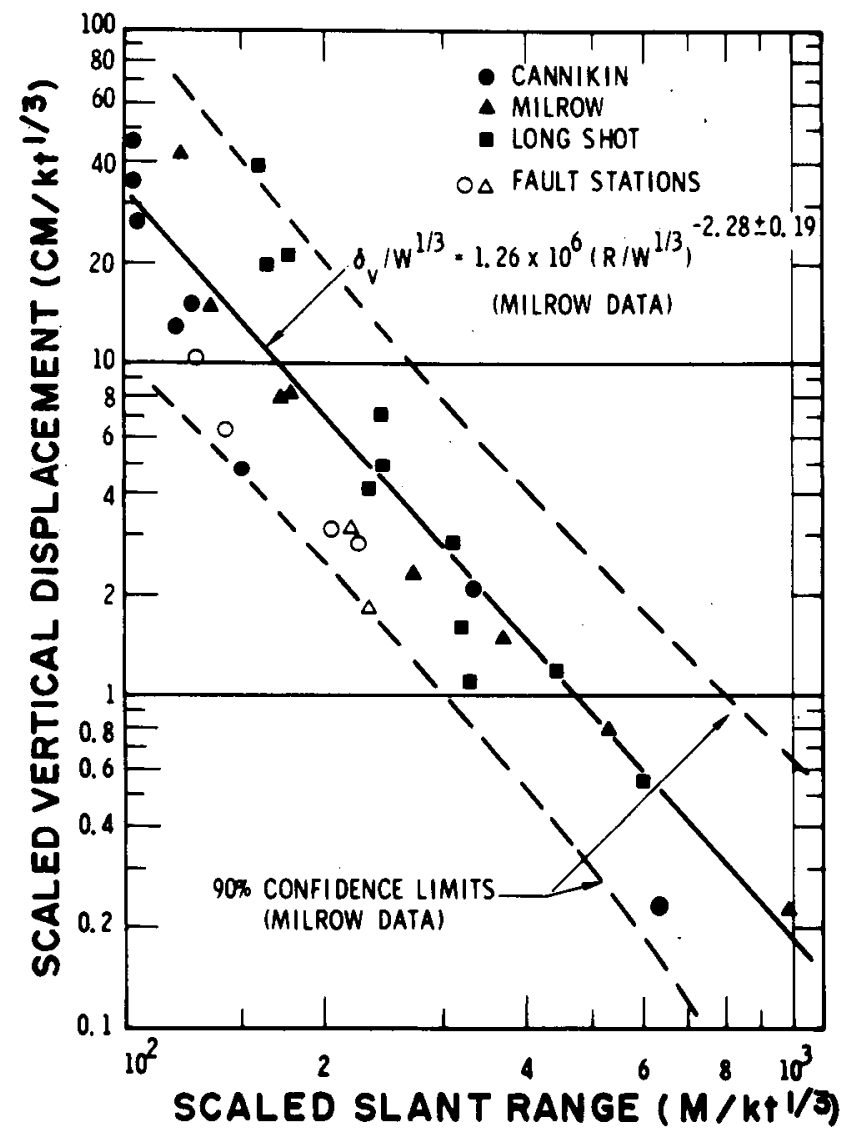

FIGURE 23. Surface Vertical Displacement Attenuation ${ }^{9}$ 


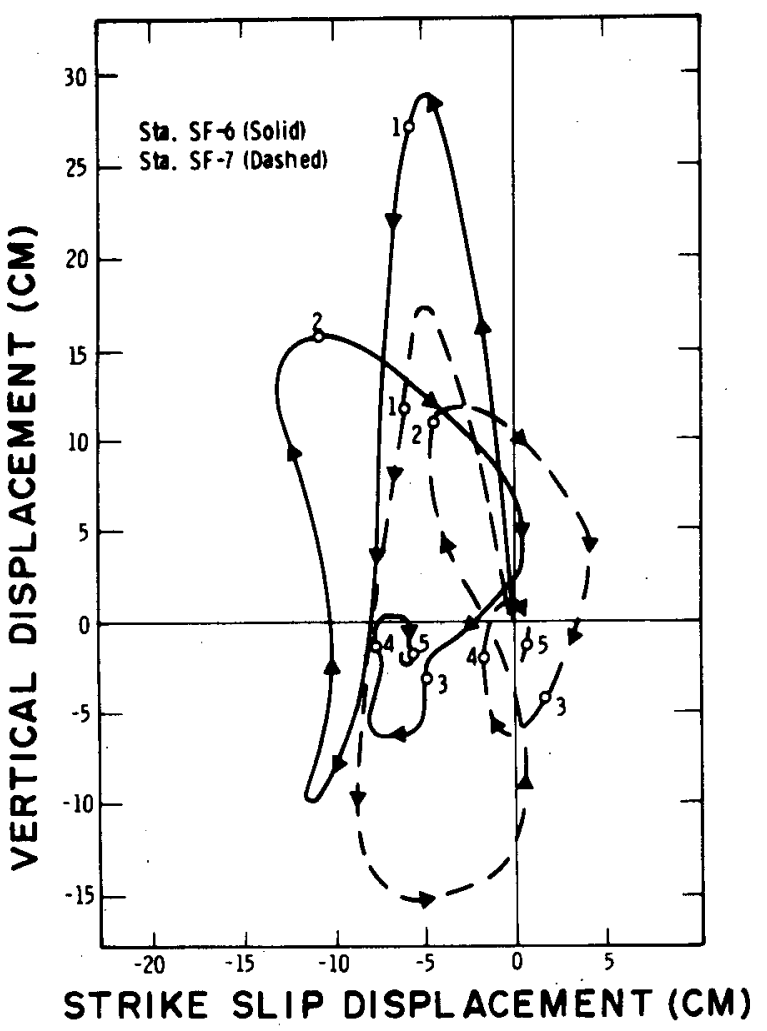

FIGURE 24. MILROW Fault Displacement Hodographs, Rifle Range Fault ${ }^{9}$ 


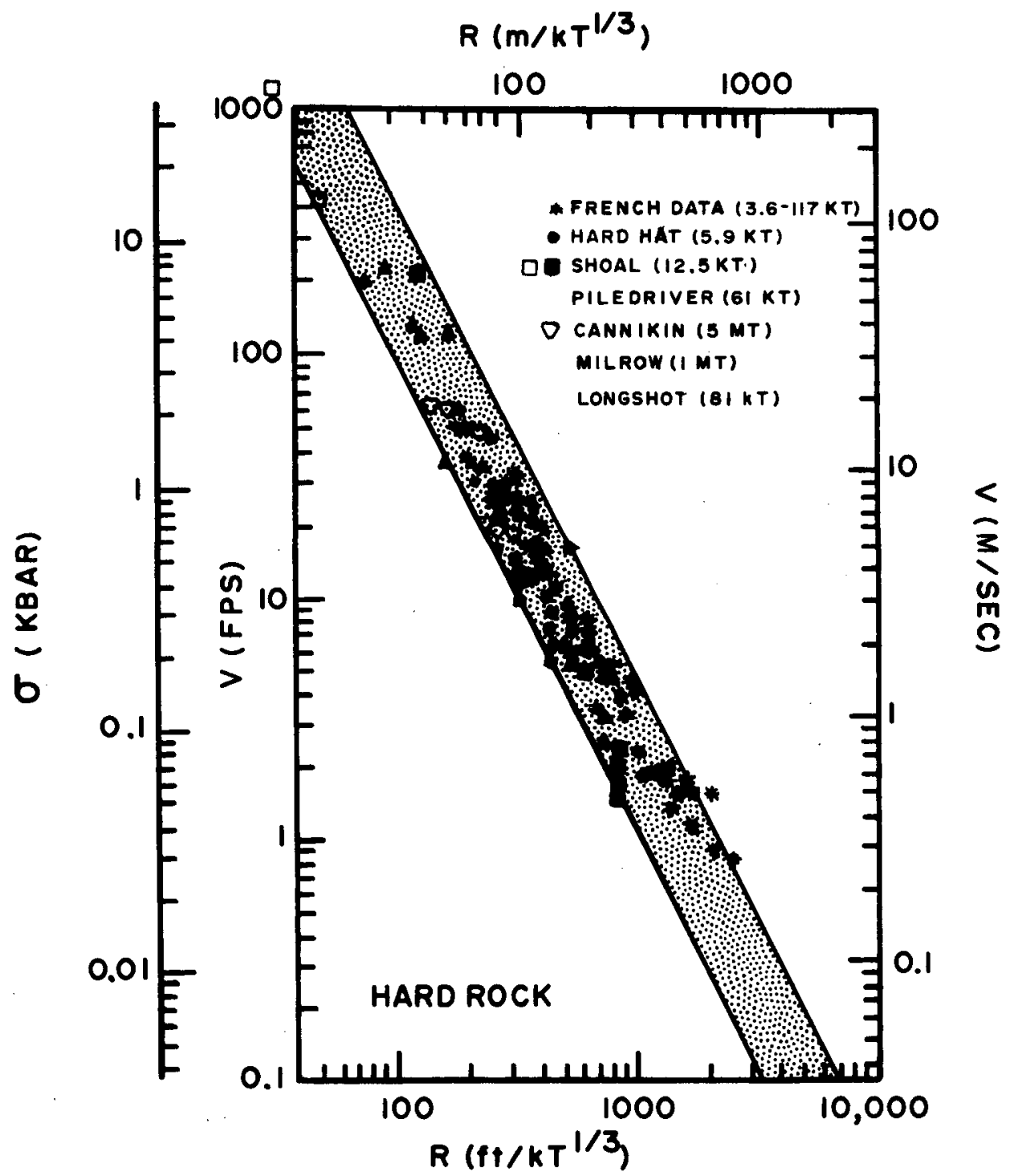

FIGURE 25. Velocity and Stress as a Function of Scaled Range 55 
Important observational data exist from the PILEDRIVER event in granite at the Nevada Test Site (NTS). The senior author, Pratt, visited the site and noted that there was no apparent permanent displacement at a range of $425 \mathrm{~m}$ where accelerations were measured at approximately $30 \mathrm{~g}$ 's. The rock was jointed but not faulted in the area observed. The conclusion is that there was no large-scale differential displacement in this granite rock mass at this acceleration level.

The GNOME nuclear event is of interest because it was located in salt in New Mexico, near the current site of a waste isolation demonstration program. The acceleration data from the 3-kt explosion are shown in Figure $26 .{ }^{56}$ These data, obtained in one of the potash mines, fell within a standard deviation of the particle acceleration - distance data obtained from a series of small chemical explosions in the same mine. The regression curve for this acceleration - distance data was

$$
\mathrm{AW}^{1 / 3}=5.10 \times 10^{5}\left(\mathrm{R} / \mathrm{W}^{1 / 3}\right)^{-2.43}
$$

Thus, this curve can be used with some confidence for predicting scaled accelerations in salt.

Direct observations of vibration response and evaluation of mines observed during nuclear events have been documented for project RIO BLANCO, RULISON, and MIGHTY EPIC. ${ }^{5-60}$ RIO BLANCO was a 90-kt event where particle velocity, acceleration, and displacement were recorded at oil shale mines located at slant range distances of 20,45 , and $110 \mathrm{~km} .^{57}$ Because of the large distances from ground zero to even the nearest mine, the peak velocity recorded was $1.14 \times 10^{-2} \mathrm{~cm} / \mathrm{sec}$, peak acceleration of $27.02 \mathrm{~cm} / \mathrm{sec}^{2}$, and maximum displacement of $2.77 \times 10^{-2} \mathrm{~cm}$ in the Colony Mine. The seismic waves were relatively short and did not cause any significant visible damage. However, the microeffects such as opening up subsurface joints and permanent microdisplacement were not analyzed. There was no significant damage due to the RIO BLANCO explosion in the mine. The average spectral response for the roof and floor from the Colony Mine is shown in Figure 27.57

The surface motions from project RULISON, a nominal 40-kt device, located in West Central Colorado, for the purpose of natural gas stimulation in sandstone have been studied in detail. The observed peak particle velocity and displacement were measured, ${ }^{8}$ and the resulting PSRV plot for station 4 at $9 \mathrm{~km}$ is presented in Figure 28. 


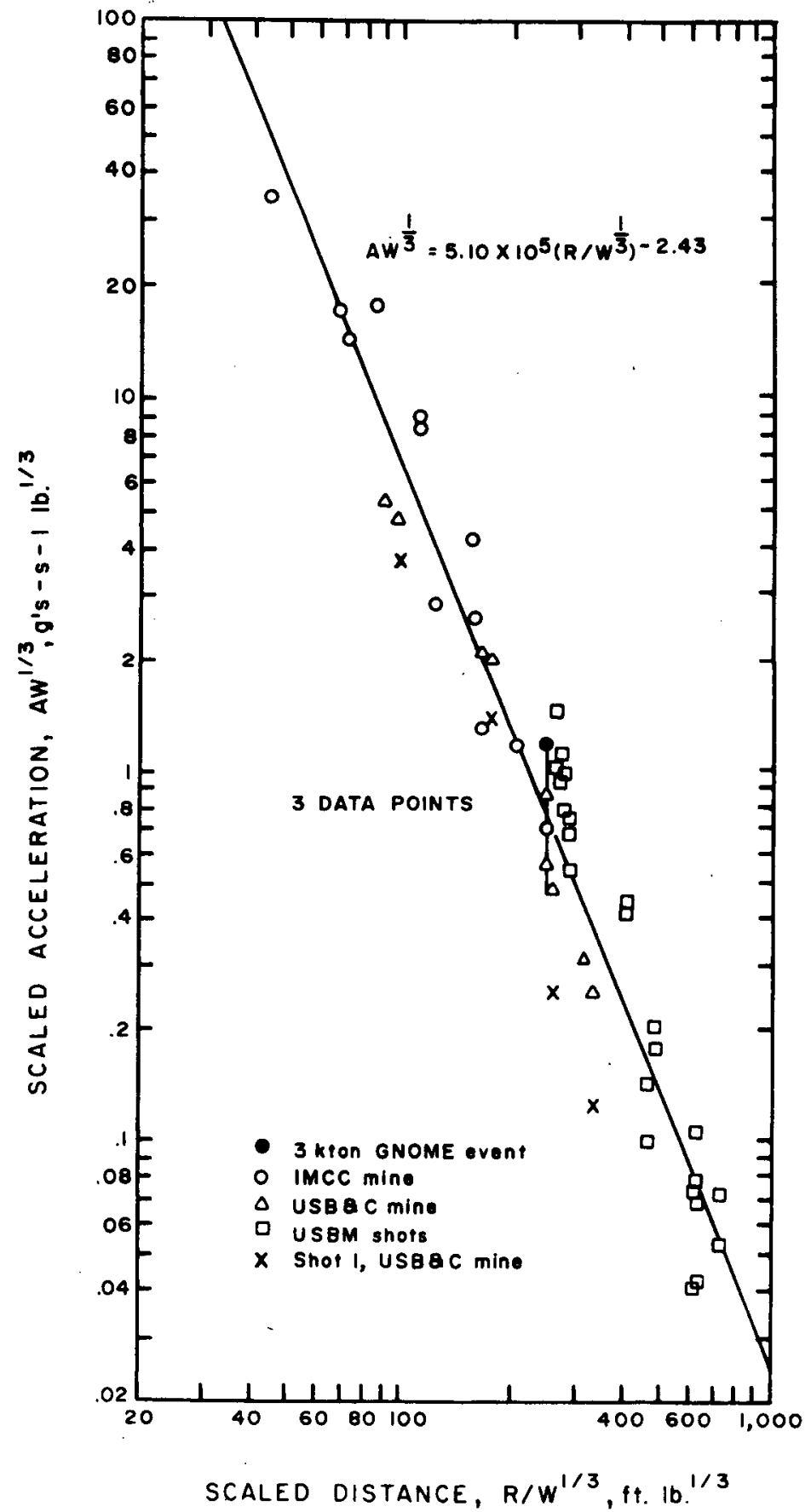

FIGURE 26. Acceleration as a Function of Scale Range for the GNOME Event ${ }^{56}$ 

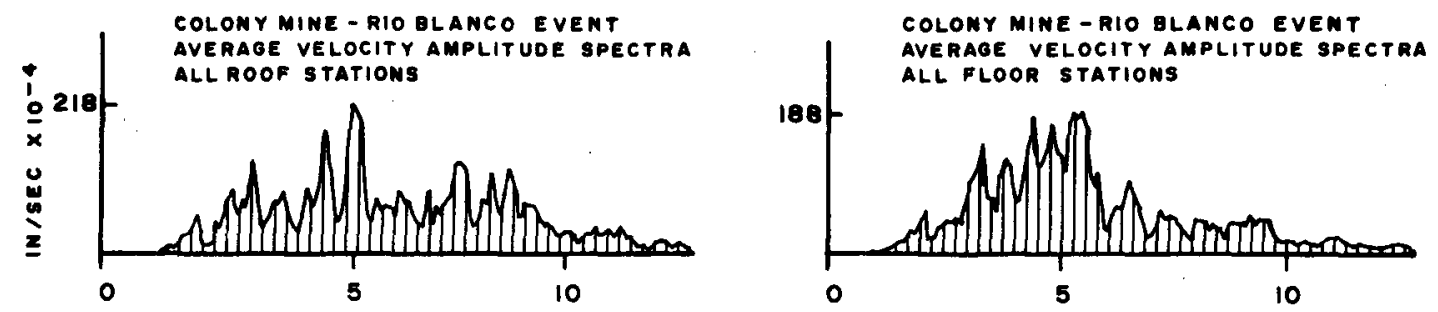

FREOUENCY IN HZ.-0.I HZ. PER DIVISION

FREOUENCY IN HZ.-O.I HZ. PER DIVISION
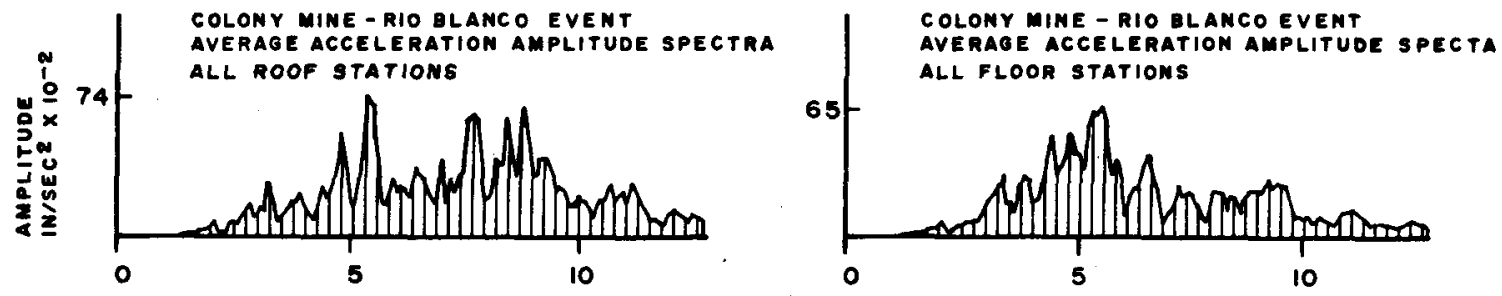

FREQUENCY IN HZ.-0.1 HZ. PER OIVISION

FREQUENCY IN HZ.- 0.1 HZ, PER DIVISION
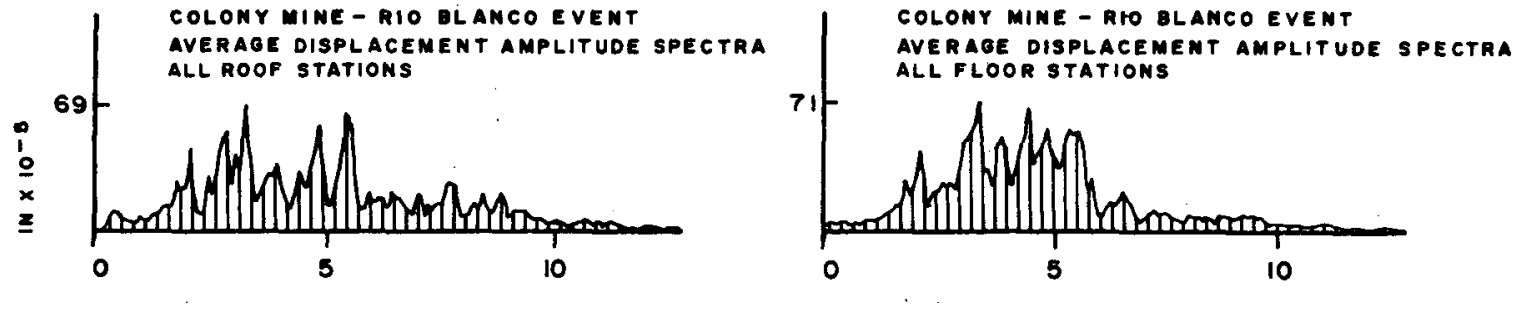

FRE QUENCY IN HZ.- O.I HZ. PER OIVISION

FREOUENCY IN HZ.-O.I HZ, PER DIVISION

FIGURE 27. Average Spectral Response for the Roof and Floor from the Colony Mine ${ }^{57}$ 


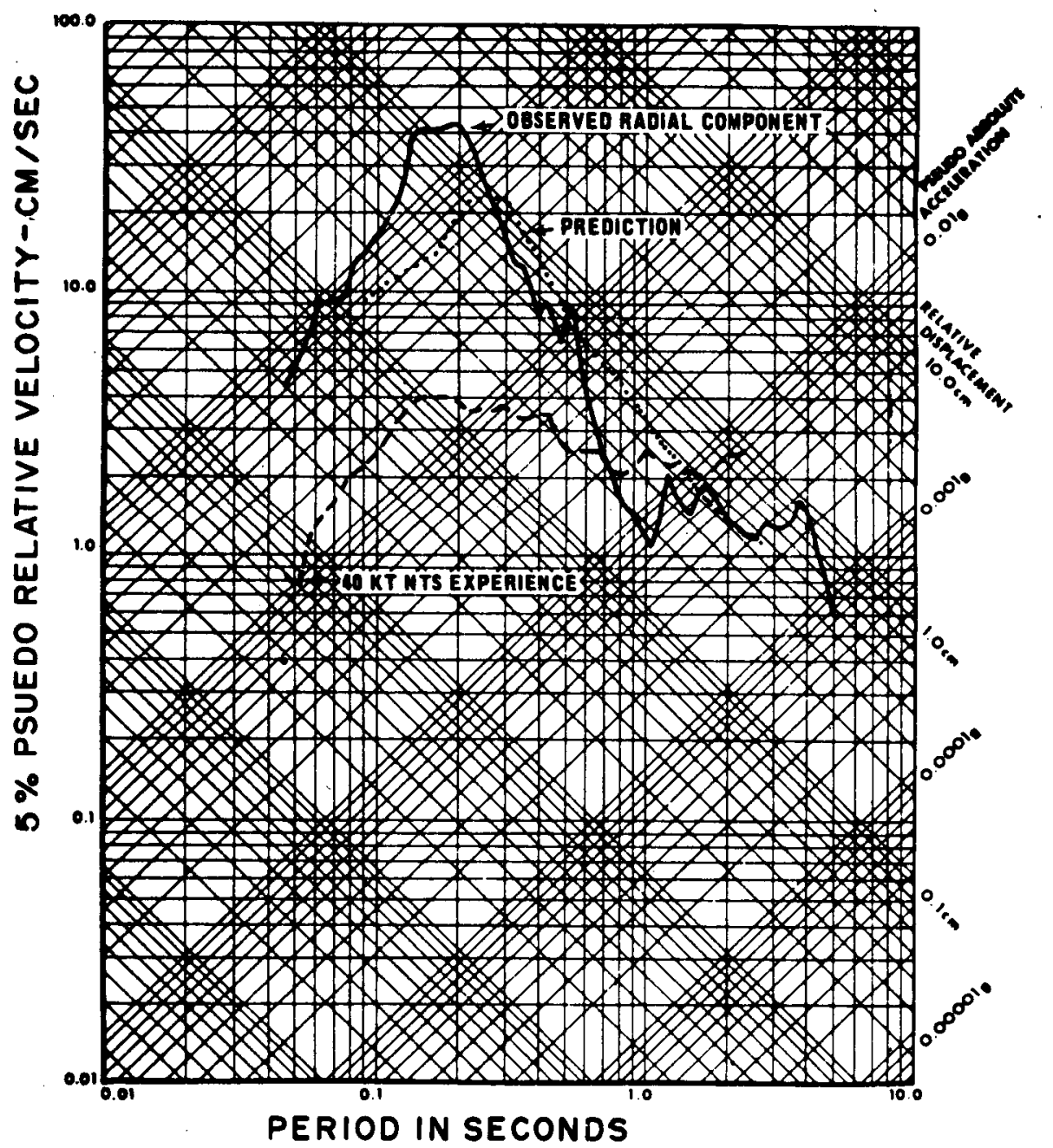

FIGURE 28. Velocity and Stress as a Function of Scaled Range for the RULISON IV Event ${ }^{58}$ 
The comparison with the 40-kt NTS data is also given in the response spectrum plot. Accelerations of $1.0 \mathrm{~g}$ were seen at slant distances of $10 \mathrm{~km}$, and relative displacements about $2.1 \mathrm{~cm}$ were noted at distances of $9 \mathrm{~km}$. A body-wave magnitude of 4.5-5.0 was recorded for the RULISON event. Surface damage was noted at a nominal distance of $8 \mathrm{~km}$. Subsurface damage to one well was noted at $3-\mathrm{km}$ radial distance from ground zero. ${ }^{59}$ The ground motion from this event was noted in coal mines at distances up to $90 \mathrm{~km} .{ }^{60}$ There was no resulting damage to the mines at these large distances.

In addition to these events, relative displacement was observed in the MIGHTY EPIC Event at the Nevada Test Site. ${ }^{61}$ A displacement of $\sim 33 \mathrm{~cm}$ was noted along a pre-existing discontinuity. This was not one of the major distontinuities in the area, but had been delineated by U.S. Geological Survey mapping in the area. This data point indicates that within a tunnel system, relative block motion can occur at moderate stress levels along a pre-existing discontinuity. The stress level was high enough so that unless a repository was in the immediate vicinity of a large earthquake, displacement of this kind would not likely be observed.

The seismological and geological evidence for block motion displacement associated with underground explosions has also been discussed by Backe and Lambert, ${ }^{53}$ based on observations on surface faulting, free field ground motions, and studies of aftershock activity. They conclude that there is a general lack of data in this field, but that the key parameter of block motion is the level of tectonic stress in the region of the explosions. They also concluded that it is unlikely that shearing block motion or large relative displacements occur outside the explosions shatter zone. They conclude from the large 1-Mt BENHAM event that an upper limit on the associated block motions for this event is $\sim 50 \mathrm{~cm}$ at ranges up to $2 \mathrm{~km}$ or so. BENHAM was equivalent to a body-wave magnitude 6.5-7.0 earthquake. They also indicate that the data base for surface events is very small, and they focused on data from contained explosion events.

In summary, a large amount of acceleration, velocity, and displacement data in the subsurface are available from nuclear tests. These data are not directly applicable in evaluating subsurface effects of earthquakes at the present time. Evaluation of these data may set upper bounds to the parameters of interest, but earthquakes differ from nuclear tests in several important respects. The surface effects of earthquakes should be greater than that of nuclear tests of equivalent body-wave magnitude because more energy goes into surface waves. Thus earthquakes of equivalent body-wave magnitude are of higher total energy content. Also a nuclear test is a point source of energy; but an earthquake is usually a dispersed source. 
Until there is a quantitative correlation of earthquakes with nuclear tests, this wealth of data should only be used qualitatively.

\section{CONCLUSIONS}

The potential seismic risk for an underground nuclear waste repository will be one of the considerations in evaluating the possible locations. A literature search and evaluation were performed to document the damage or non-damage to underground facilities due to earthquakes. Damage was delineated in terms of displacements and accelerations. The sources of data include both U.S. and foreign experiences of earthquake damage to tunnels, mines, wells, and other underground facilities. An analysis of the damage from documented nuclear events was also evaluted where applicable.

The major conclusions developed from an assessment of the information obtained in this study are summarized as follows:

- There are very few data on damage in the subsurface due to earthquakes. This fact itself attests to the lessened effect of earthquakes in the subsurface because mines exist in areas where strong earthquakes have done extensive surface damage.

- More damage is reported in shallow, near-surface tunnels than in deep mines. Specifically, data are very sparse below $500 \mathrm{~m}$.

- In mines and tunnels, large displacements occur primarily along pre-existing faults and fractures or at the surface entrance to these facilities.

- Data indicate vertical structures such as wells and shaft are also not as susceptible to damage as are surface facilities. Even in the Alaska earthquake of $1964(\mathrm{M}=8.5)$ few we11s were damaged in Anchorage except those sheared by landslides.

- Not enough data were found to assess the exact influence of rock type; however, the effects are less in consolidated materials than unconsolidated materials, such as alluvium. Geologic structures, such as faults, seem to be a dominant factor in underground damage.

- Frequencies most likely to cause damage to subsurface facilities are significantly higher $(50-100 \mathrm{~Hz})$ than the frequencies $(2-10 \mathrm{~Hz})$ that cause damage to surface facilities.

- Acceleration and displacement data from nuclear explosions can give close-in upperbound limits for large earthquakes when a facility is very near the epicenter.

- More analysis is required before a seismic criteria can be formulated for the siting of a nuclear waste repository. 
APPENDIX A - EARTHQUAKE DAMAGE TO TUNNELS

(Data Summarized from Reference 2)
No. Earthquake
1 Central CA (San Francisco)
Tronne 2
Wright-1

$1 \mathrm{a}$

1b

2 San Francisco 1906

$2 a$

$2 b$

3

Tokyo, 1923

(Kwanto)

4

5

6
Damage Due to

$\begin{array}{lll}\text { Shaking } & \text { Fault Movement } & \begin{array}{l}\text { Ground Failure and } \\ \text { Other Reasons }\end{array} \\ \text { Caving in of rock } & \text { Caving in of rock } \\ \text { and some breaking } & \text { from roof and sides. } \\ \text { of timber but to } & \text { Breaking in flexure } \\ \text { lesser extent com- } & \text { of upright timber. } \\ \text { pared to damage } & \text { Upward heaving of } \\ \text { near the fault. } & \text { rails. Breaking of } \\ & \text { ties. Blocked in } \\ & \text { several points. } \\ & \text { Transverse horizontal } \\ & \text { offset of 4.5 ft } \\ & \text { under the fault. }\end{array}$

No damage.

No damage.

Broken timber, roof caved in.

No damage.

No damage.

Wright-2

Terao

Hichigama

Taura

Numana

Nokogi ri - Yama

Concrete walls fractured slightly. Some spalling of concrete.

Kanome- Yama

Ajo

Ippamatzu

Masonry dislodged near floor in interior.

Nagoye

Komine
Interior cracked.

Destroyed. RC blocks

tilted. Ceiling slabs

caved in. Formed section cracked.
Cracked brick portal.

Landslide at entrance.

Landslide at entrance.

Cracked brick portal.

Entrance buried by landslide. Some damage to masonry portal.

Landslides at entrance. Damage to masonry portal.

Cracks in masonry near portals. 


\begin{tabular}{|c|c|c|c|c|c|}
\hline No. & Earthquake & Tunnel & Shaking & Fault Movement & $\begin{array}{l}\text { Ground Faiture and } \\
\text { Other Rearons }\end{array}$ \\
\hline 13 & & Fudu San & Clean interior. & & Cracked masonry portal. \\
\hline 14 & & Meno-Kami ama & Partial collapse. & & \\
\hline 15 & & Yonegami-Yama & $\begin{array}{l}\text { Minor interior } \\
\text { masonry damage. }\end{array}$ & & Cracks near portal. \\
\hline 16 & & Shimomaki-Matsu & $\begin{array}{l}\text { Deformed masonry } \\
\text { in interior. }\end{array}$ & & $\begin{array}{l}\text { Portals closed by } \\
\text { slides. }\end{array}$ \\
\hline 17 & & Happon-Matsu & $\begin{array}{l}\text { Badly cracked } \\
\text { interior. }\end{array}$ & & Buried by slides. \\
\hline 18 & & Nagasahu Yama & $\begin{array}{l}\text { Some interior frac- } \\
\text { tures in brick and } \\
\text { concrete. }\end{array}$ & & \\
\hline 19 & & Hakone-1 & Interior cracked. & & \\
\hline 20 & & Hakone-2 & Undamaged. & & \\
\hline 21 & & Hakone- 3 & Cracks in interior. & & $\begin{array}{l}\text { Ceiling collapsed near } \\
\text { portal. Some damage } \\
\text { to masonry portal. }\end{array}$ \\
\hline 22 & . & Hakone-4 & $\begin{array}{l}\text { Collapse of loose } \\
\text { material. }\end{array}$ & & $\begin{array}{l}\text { Entrance almost com- } \\
\text { pletely buried. }\end{array}$ \\
\hline 23 & & Hakone- 7 & Interior collapse. & & $\begin{array}{l}\text { Landslides buried } \\
\text { entrances. }\end{array}$ \\
\hline 24 & & Yose & $\begin{array}{l}\text { Shallow portions } \\
\text { collapsed and day- } \\
\text { lighted. }\end{array}$ & & \\
\hline 25 & & Doki & $\begin{array}{l}\text { Collapses at shallow } \\
\text { parts. }\end{array}$ & & \\
\hline 26 & & Humuya & $\begin{array}{l}\text { Cave in. Cracks with } \\
10-\text { inch }(25 \mathrm{~cm}) \\
\text { displacement. }\end{array}$ & · & Landslide. \\
\hline 27 & & Mineoka-Yama & $\begin{array}{l}\text { Cracks in bulges in } \\
\text { masonry from local } \\
\text { earth pressure. }\end{array}$ & & \\
\hline 28 & $\begin{array}{l}\text { Idu Peninsula, } \\
1930\end{array}$ & Tanna & Few cracks in walls. & $\begin{array}{l}7 \text { ft } 10 \text { in. horizontal } \\
\text { displacement, } 2 \text {-ft } \\
\text { vertical displacement } \\
\text { just across the Tanna } \\
\text { fault. }\end{array}$ & \\
\hline 29 & Fukui, 1948 & Kumasaka & & & $\begin{array}{l}\text { Brick arches of portal } \\
\text { partially fractured. }\end{array}$ \\
\hline 30 & $\begin{array}{l}\text { Off Tokachi, } \\
1952\end{array}$ & & $\begin{array}{l}\text { Minor cracks in both } \\
\text { brick and concrete } \\
\text { linings. }\end{array}$ & & \\
\hline
\end{tabular}




\begin{tabular}{|c|c|c|c|c|}
\hline & & & Damage Due to & \\
\hline No. & Earthquake & Tunnel & Shaking & $\begin{array}{ll}\text { Fault Movement } & \begin{array}{l}\text { Ground Failure and } \\
\text { Other Reasons }\end{array}\end{array}$ \\
\hline 31 & $\begin{array}{l}\text { Kern County, } \\
1952\end{array}$ & S. P. R. R. 3 & & $\begin{array}{l}\text { Wrecked under } \\
\text { White Wolf fault. } \\
\text { Daylighted. }\end{array}$ \\
\hline $31 a$ & (Aftershock) & S. P. R. R, 3 & No damage. & \\
\hline $31 b$ & (Aftershock) & S. P. R. R. 3 & No damage. & \\
\hline 32 & & S. P. R. R. 4 & & $\begin{array}{l}\text { Wrecked under fault. } \\
\text { Daylighted. }\end{array}$ \\
\hline 33 & & S. P. R. R. 5 & & Wrecked under fault. \\
\hline $33 a$ & (Aftershock) & S. P. R. R. 5 & No damage. & \\
\hline $33 b$ & (Aftershock) & S. P. R. R. 5 & No damage. & \\
\hline 34 & & S. P. R. R. 6 & & Fractured, daylighted. \\
\hline $34 a$ & (Aftershock) & S. P. R. R. 6 & No damage. & : $\cdot$ \\
\hline $34 b$ & (Aftershock) & S. P. R. R. 6 & No damage. & \\
\hline 35 & $\begin{array}{l}\text { Kita Mino, } \\
1961\end{array}$ & Powerhouse & No damage. & \\
\hline 36 & & Aqueduct & Cracking. & \\
\hline 37 & $\begin{array}{l}\text { Niigata, } \\
1964\end{array}$ & Nezugaseki & $\begin{array}{l}\text { Spalling of concrete } \\
\text { at crown. }\end{array}$ & Cracking at portal. \\
\hline 38 & & Terasaka & $\begin{array}{l}\text { Spalling of concrete } \\
\text { at crown, crushing of } \\
\text { invert at bottom of } \\
\text { sidewalls. }\end{array}$ & . \\
\hline 39 & $\begin{array}{l}\text { Great Alaska } \\
1964\end{array}$ & Whittier-1 & $\begin{array}{l}\text { Some overhead ravel- } \\
\text { ling of loose rock } \\
\text { which falls on the } \\
\text { track. }\end{array}$ & . \\
\hline 40 & & Whittier-2 & No damage. & \\
\hline 41 & & Seward-1 & No damage. & . \\
\hline 42 & & Seward-2 & No damage. & \\
\hline 43 & & Seward- 3 & No damage. & \\
\hline 44 & & Seward- 4 & No damage. & \\
\hline 45 & & Seward-5 & No damage. & \\
\hline 46 & & Seward- 6 & No damage. & \\
\hline 47 & $\begin{array}{l}\text { San Fernando, } \\
1971\end{array}$ & Ba1boa & 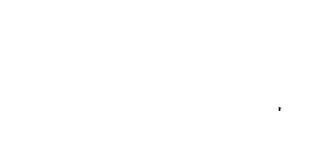 & $\begin{array}{l}\text { Severe spalling, breaking of concrete lining, } \\
\text { deformations where tunnel passed under canyon } \\
\text { at shallow cover, only } 36 \mathrm{~m}(120 \mathrm{ft}) \text { south } \\
\text { of Santa Suzana fault. No breaking of re- } \\
\text { inforcing bar at RC blocks. }\end{array}$ \\
\hline
\end{tabular}





\section{EARTHQUAKES' DATA}

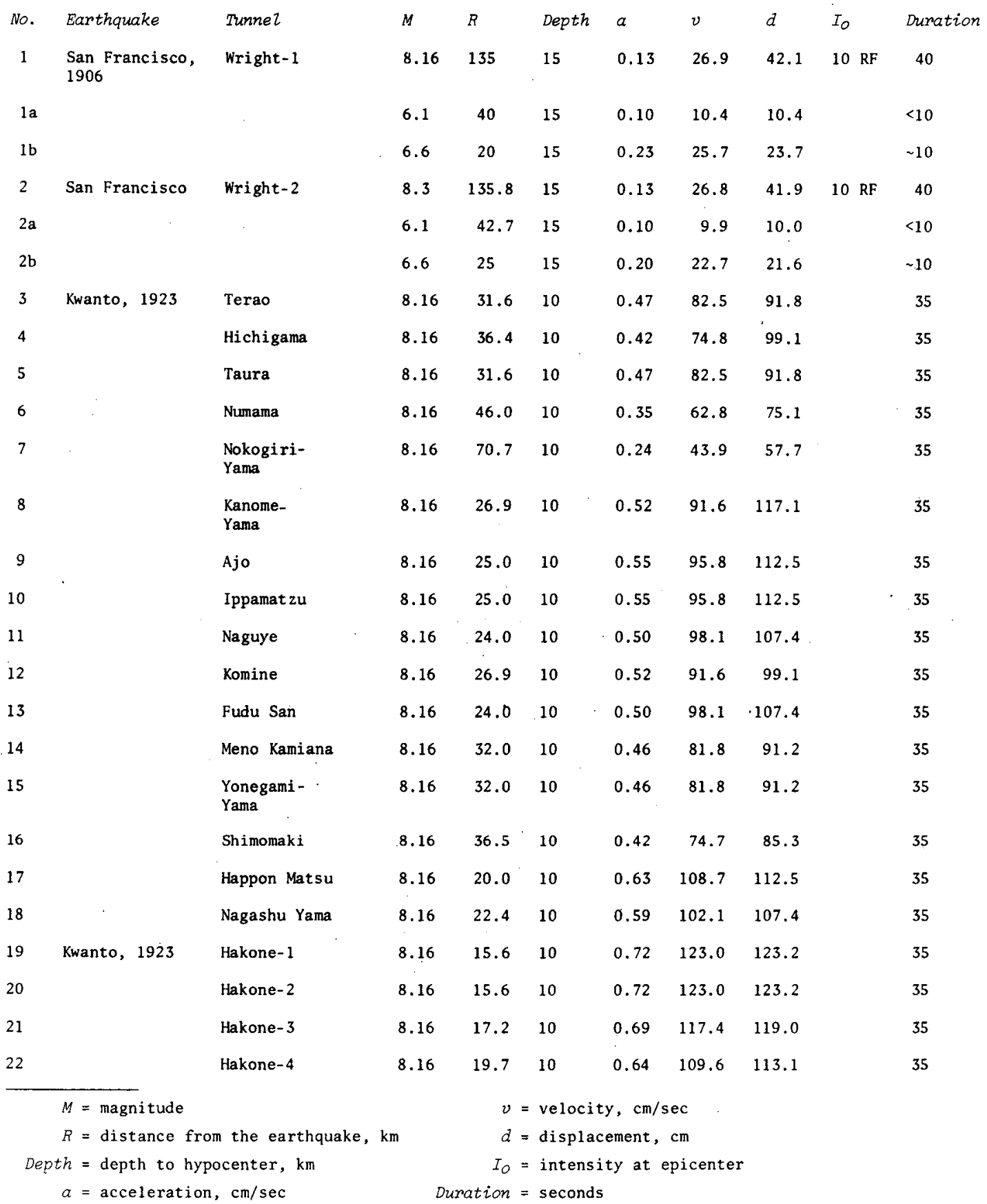




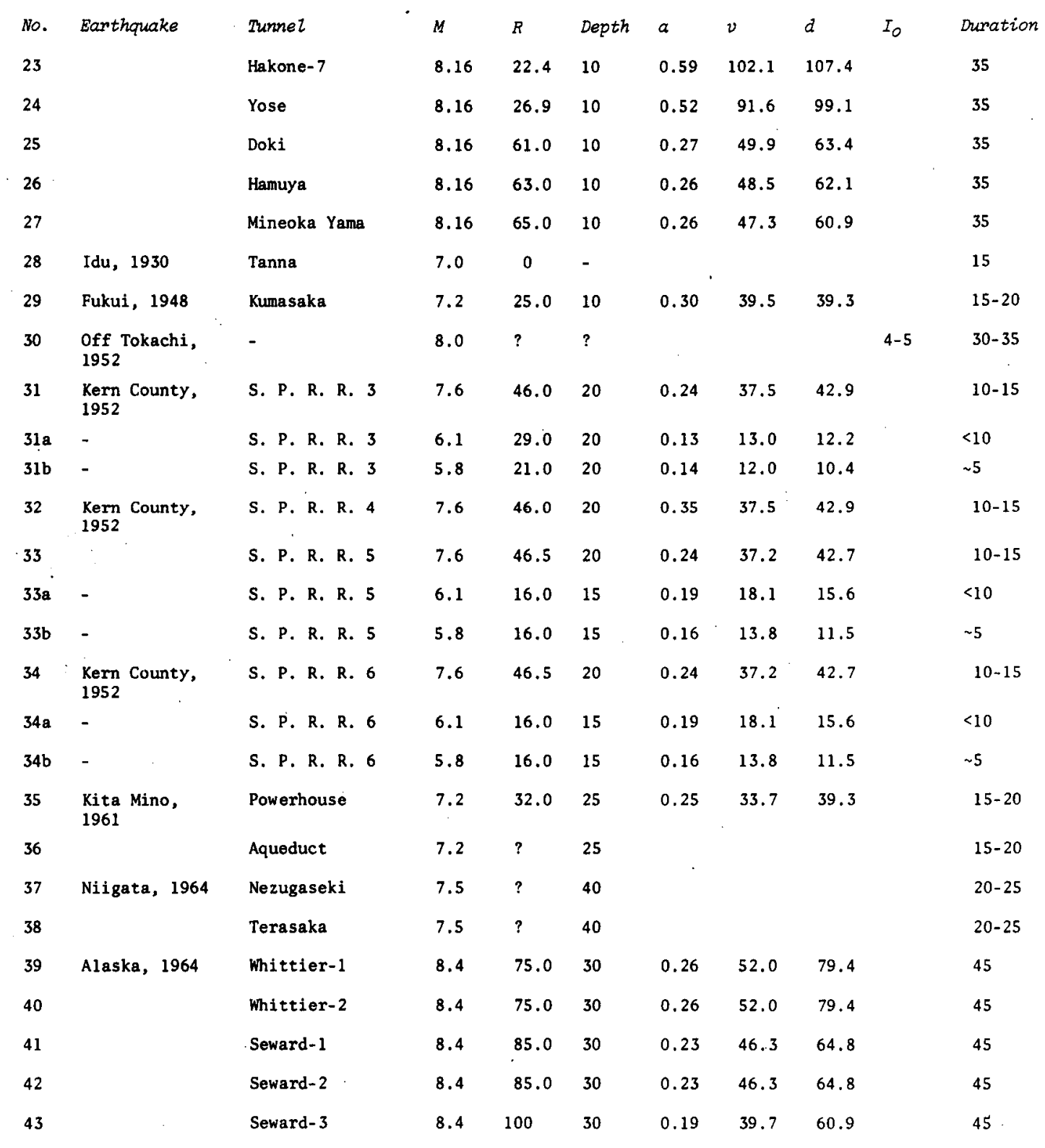




\begin{tabular}{|c|c|c|c|c|c|c|c|c|c|}
\hline Earthquake & Thonel & $M$ & $R$ & Depth & $a$ & $v$ & $d$ & $I_{O}$ & Duration \\
\hline 44 & Seward-4 & 8.4 & 100 & 30 & 0.19 & 39.7 & 60.9 & & 45 \\
\hline 45 & Seward-5 & 8.4 & 110 & 30 & 0.19 & 36.2 & 56.7 & & 45 \\
\hline 46 & Seward-6 & 8.4 & 115 & 30 & 0.17 & 34.7 & 56.7 & & 45 \\
\hline $\begin{array}{l}\text { San Fernando, } \\
1971\end{array}$ & Balboa & 6.4 & 16 & 13 & 0.23 & 23.9 & 21.0 & $8-9$ & 15 \\
\hline $\begin{array}{l}\text { San Fernando, } \\
1971\end{array}$ & San Fernando & 6.4 & 16 & 13 & 0.23 & 23.9 & 21.0 & & 15 \\
\hline $\begin{array}{l}\text { San Fernando, } \\
1971\end{array}$ & McLay & 6.4 & 16 & 13 & 0.23 & 23.9 & 21.0 & & 15 \\
\hline $\begin{array}{l}\text { San Fernando, } \\
1971\end{array}$ & Chatsworth & 6.4 & 20 & 13 & 0.20 & 21.4 & 19.4 & & 15 \\
\hline $\begin{array}{l}\text { San Fernando, } \\
1971\end{array}$ & Tehachapi-1 & 6.4 & 70 & 13 & 0.08 & 8.7 & 10.0 & $\cdot$ & 15 \\
\hline $\begin{array}{l}\text { San Fernando, } \\
1971\end{array}$ & $\begin{array}{l}\text { Van Norman } \\
\text { Inlet }\end{array}$ & 6.4 & 33 & 13 & 0.15 & 15.8 & 15.5 & & 15 \\
\hline $\begin{array}{l}\text { San Fernando, } \\
1971\end{array}$ & Tehachapi-2 & 6.4 & 73 & 13 & 0.07 & 8.4 & 9.7 & & 15 \\
\hline $\begin{array}{l}\text { San Fernando, } \\
1971\end{array}$ & Tehachapi-3 & 6.4 & 73 & 13 & 0.07 & 8.4 & 9.7 & & 15 \\
\hline $\begin{array}{l}\text { San Fernando, } \\
1971\end{array}$ & Carley Porter & 6.4 & 65 & 13 & 0.08 & 9.3 & 10.5 & & 15 \\
\hline $\begin{array}{l}\text { San Fernando, } \\
1971\end{array}$ & $\begin{array}{l}\text { Van Norman } \\
\text { North }\end{array}$ & 6.4 & 23 & 13 & 0.19 & 19.8 & 18.3 & . & 15 \\
\hline $\begin{array}{l}\text { San Fernando, } \\
1971\end{array}$ & Saugus & 6.4 & 23 & 13 & 0.19 & 19.8 & 18.3 & & 15 \\
\hline 58 & San Francisquito & 6.4 & 24.5 & 13 & 0.18 & 19.1 & 17.8 & & 15 \\
\hline 59 & Elizabeth & 6.4 & 27.3 & 13 & 0.17 & 17.9 & 17.0 & & 15 \\
\hline 60 & Antelope & 6.4 & 37.5 & 13 & 0.13 & 14.4 & 14.5 & & 15 \\
\hline Inyokern, 1946 & Jawbone & 6.3 & 26.0 & 15 & 0.16 & 16.8 & 15.7 & & \\
\hline 62 & Jawbone & 6.3 & 28.0 & 15 & 0.16 & 16.0 & 15.2 & & \\
\hline 63 & Jawbone & 6.3 & 31.0 & 15 & 0.14 & 15.0 & 14.4 & & \\
\hline 64 & Freeman & 6.3 & 22.0 & 15 & 0.18 & 18.5 & 16.9 & & \\
\hline $\begin{array}{l}\text { Arvin } \\
\text { Tehachapi, } 1952\end{array}$ & Saugus & 7.7 & 90.0 & 20 & 0.14 & 23.0 & 31.0 & & \\
\hline 66 & San Francisquito & 7.7 & 75.0 & 20 & 0.17 & 27.2 & 35.0 & & \\
\hline 67 & Elizabeth & 7.7 & 70.0 & 20 & 0.18 & 29.0 & 36.7 & & \\
\hline 68 & Antelope & 7.7 & 48.0 & 20 & 0.25 & 39.7 & 46.3 & & \\
\hline 69 & Jawbone & 7.7 & 90.0 & 20 & 0.14 & 23.0 & 31.0 & & \\
\hline Chalone, 1922 & Jawbone & 6.1 & 52.0 & 20 & 0.08 & 8.5 & 8.9 & & \\
\hline 71 & Freeman & 6.1 & 52.0 & 20 & 0.08 & 8.5 & 8.9 & & \\
\hline
\end{tabular}




\section{APPENDIX B - EFFECTS OF THE MARCH 1964 EARTHQUAKE ON WELLS OF THE ALASKA AREA}

(Data Summarized from: Reference 46)

\begin{tabular}{|c|c|c|c|c|c|c|}
\hline No. ${ }^{a}$ & $\begin{array}{l}\text { Depth, } \\
\text { meters }\end{array}$ & $\begin{array}{l}\text { Diameter, } \\
\text { meters }\end{array}$ & $\begin{array}{l}\text { Water le } \\
\text { (below } \\
\text { Before }\end{array}$ & $\begin{array}{l}\text { eve } \text {, } \\
\text { Zand }\end{array}$ & $\begin{array}{l}\text { meters } \\
\text { ourface) } \\
\text { After }\end{array}$ & Earthquake Effects \\
\hline 1 & 19.8 & 0.1524 & & & & $\begin{array}{l}\text { Water level dropped } 7.6 \mathrm{~m} \text {. Fissure } \\
\text { nearby; pumped sand. }\end{array}$ \\
\hline 2 & 13.7 & 0.1524 & & & & $\begin{array}{l}\text { Well went dry; drilled another well } \\
\text { to } 49 \mathrm{~m} \text {. }\end{array}$ \\
\hline 3 & 19.5 & 0.1524 & 9.5 & & 10.8 & $\begin{array}{l}\text { Water level probably fell at least } \\
1.5 \mathrm{~m} \text {. }\end{array}$ \\
\hline 4 & 45.7 & 0.2032 & Flowing & & Flowing & Unaffected. \\
\hline 5 & 22.2 & 0.1524 & & & & Unaffected. \\
\hline 6 & 14.9 & 0.1524 & 10.4 & & & Reportedly went dry; was redrilled. \\
\hline 7 & 17.1 & 0.1524 & 2.6 & & 2.3 & Unaffected. \\
\hline 8 & 17.2 & 0.1524 & & & & Muddy for 1 day. \\
\hline 9 & 15.8 & 0.1524 & & & & $\begin{array}{l}\text { Went dry and drilled to } 37.5 \mathrm{~m} \\
\text { in 4-64 water level now } 9.1 \mathrm{~m} \text {. }\end{array}$ \\
\hline 10 & 37.2 & 0.1524 & 21.9 & & & Unaffected. \\
\hline 11 & 41.4 & 0.1524 & 39.0 & & & $\begin{array}{l}\text { Went dry } 3 \text { weeks after quake. } \\
\text { Deepened } 4 \mathrm{~m} \text {. }\end{array}$ \\
\hline 12 & 40.8 & 0.1524 & 13.6 & & 17.6 & Water leve 1 dropped at least $4 \mathrm{~m}$. \\
\hline 13 & 138.1 & 0.2032 & 14.2 & & 21.7 & Water level dropped at least $7.6 \mathrm{~m}$. \\
\hline 14 & 18.9 & 0.1524 & 7.6 & & & Muddy for 1 day. \\
\hline 15 & 65.2 & 0.1524 & & & & $\begin{array}{l}\text { Went dry about } 1 \text { month after quake. } \\
\text { Deepened } 3 \mathrm{~m} \text { with less production } \\
\text { than before quake. }\end{array}$ \\
\hline 16 & 64.9 & 0.1524 & 62.8 & & & Went dry; recovery unknown. \\
\hline 17 & 30.5 & 0.1524 & 25.1 & & & Muddy for about 1 week. \\
\hline 18 & 39.3 & 0.1524 & 25.9 & & & Muddy for 2 days. \\
\hline 19 & 78.6 & 0.2032 & 1.5 & & 7.0 & $\begin{array}{l}\text { Water leve } 1 \text { dropped about } 5.8 \mathrm{~m} \text {; } \\
\text { still recovering }(10-64) .\end{array}$ \\
\hline 20 & & & Flowing & & & Lost artesian flow; has not returned. \\
\hline 21 & 106.4 & 0.1524 & 34.1 & & 28.9 & $\begin{array}{l}\text { Water level rose and fell; now at } \\
40 \mathrm{~m}(9-64) \text {. }\end{array}$ \\
\hline 22 & 41.1 & 0.0762 & 18.0 & & & Muddy for 2 days. \\
\hline 23 & 97.5 & 0.1524 & 12.4 & & 22.7 & $\begin{array}{l}\text { Water level rose and fell; still } \\
\text { recovering at } 16.4 \mathrm{~m}(9-64) \text {. }\end{array}$ \\
\hline 24 & 82.3 & 0.254 & 26.4 & & 26.9 & Unaffected. \\
\hline 25 & 54.9 & 0.254 & & & & Unaffected. \\
\hline
\end{tabular}

a. Well numbers refer to those on map in U. S. G. S. Professional Paper 544B. ${ }^{46}$ 


\begin{tabular}{|c|c|c|c|c|c|}
\hline No. & $\begin{array}{l}\text { Depth, } \\
\text { meters }\end{array}$ & $\begin{array}{l}\text { Diameter, } \\
\text { meters }\end{array}$ & $\begin{array}{l}\text { Water Level, } \\
\text { (below Land } \\
\text { Before }\end{array}$ & $\begin{array}{l}\text { meters } \\
\text { ourfacel }\end{array}$ & Earthquake Effects \\
\hline 26 & 50.3 & 0.1524 & & & $\begin{array}{l}\text { Pumped sand for } 2 \text { days. Water } \\
\text { level unchanged. }\end{array}$ \\
\hline 27 & 50.3 & 0.1524 & 47.8 & & Went dry, possibly still dry. \\
\hline 28 & 59.4 & 0.1524 & 7.0 & & Muddy about 1 day. \\
\hline 29 & 87.2 & 0.1524 & 12.8 & & $\begin{array}{l}\text { Went dry; came back about } 1 \text { month } \\
\text { later. }\end{array}$ \\
\hline 30 & 62.8 & 0.1524 & 1 & & Pumped sand for 1 day or so. \\
\hline 31 & 27.4 & 0.1524 & 7.6 & & $\begin{array}{l}\text { Muddy for undeterminable length of } \\
\text { time. }\end{array}$ \\
\hline 32 & 19.2 & 0.1524 & & & Unaffected. \\
\hline 33 & 148.1 & & Flowing & 7.6 & $\begin{array}{l}\text { Water level dropped about } 7.6 \mathrm{~m} \text {. } \\
\text { Completely recovered. }\end{array}$ \\
\hline 34 & 35.0 & 0.1524 & 1.2 & 3.6 & $\begin{array}{l}\text { Muddy for } 2 \text { days; water level } \\
\text { dropped about } 2.4 \mathrm{~m} \text {. }\end{array}$ \\
\hline 35 & 14.0 & 0.1524 & 4.3 & & $\begin{array}{l}\text { Pumped sand; strong odor for } 1 / 2 \\
\text { day. }\end{array}$ \\
\hline 36 & 40.8 & 0.1524 & 4.1 & 4.6 & Water level dropped at least $0.3 \mathrm{~m}$. \\
\hline 37 & 30.5 & 0.1524 & 8.2 & 11.5 & $\begin{array}{l}\text { Water level dropped about } 3 \mathrm{~m} \text {; } \\
\text { recovered } 1.8 \mathrm{~m} \text {. }\end{array}$ \\
\hline 38 & 69.5 & 0.2032 & 46.9 & & Unaffected. \\
\hline 39 & 61.0 & 0.1524 & Flowing & & Unaffected. \\
\hline 40 & 112.8 & 0.2032 & 37.4 & 36.9 & $\begin{array}{l}\text { Water level probably dropped; fast } \\
\text { recovery. }\end{array}$ \\
\hline 41 & 14.8 & 0.1524 & 11.6 & & Muddy for 4 days. \\
\hline 42 & 16.8 & & 12.2 & 11.5 & May have dropped before recovering. \\
\hline 43 & 11.3 & 0.1524 & 9.1 & & Unaffected. \\
\hline 44 & 42.3 & 0.2032 & 5.6 & 7.7 & May have dropped more than $2.1 \mathrm{~m}$. \\
\hline 45 & 48.5 & 0.254 & 9.8 & & Unaffected. \\
\hline 46 & 68.6 & 0.2032 & 7.8 & 9.0 & Dropped at least $1.2 \mathrm{~m}$. \\
\hline 47 & 6.1 & 0.1524 & 2.4 & 2.8 & Possibly dropped $0.46 \mathrm{~m}$. \\
\hline 48 & 32.0 & 0.1524 & 7.1 & & $\begin{array}{l}\text { Muddy for about } 2 \text { weeks; water } \\
\text { level dropped slightly. }\end{array}$ \\
\hline 49 & 29.9 & 0.1524 & 7.1 & & Unaffected. \\
\hline 50 & 37.5 & 0.1524 & 5.8 & & Unaffected. \\
\hline 51 & 6.7 & 0.1524 & 1.5 & & Muddy for 2 days. \\
\hline 52 & 143.2 & 0.2032 & 23.0 & & Casing bent and broken. \\
\hline 53 & 45.4 & 0.1524 & 7.1 & & Unaffected. \\
\hline 54 & 64.0 & 0.2032 & 16.0 & 20.5 & $\begin{array}{l}\text { Dropped at least } 4.6 \mathrm{~m} \text {; maybe } \\
\text { partly due to pumpage. }\end{array}$ \\
\hline
\end{tabular}




\begin{tabular}{|c|c|c|c|c|c|}
\hline No. & $\begin{array}{l}\text { Depth, } \\
\text { meters }\end{array}$ & $\begin{array}{l}\text { Diameter, } \\
\text { meters }\end{array}$ & $\begin{array}{l}\text { Water Level, } \\
\text { (below Zand } \\
\text { Before }\end{array}$ & $\begin{array}{c}\text { meters } \\
\text { surface) }\end{array}$ & Earthquake Effects \\
\hline 55 & 69.2 & 0.1524 & & & Unaffected. \\
\hline 56 & 95.4 & 0.1524 & 0.61 & & $\begin{array}{l}\text { Muddy } 2 \text { days; production poor at } \\
\text { low tides now. }\end{array}$ \\
\hline 57 & 32.3 & 0.1524 & 9.1 & & Muddy for 1 day. \\
\hline 58 & 47.8 & 0.2032 & Flowing & Flowing & Muddy for 3 days. \\
\hline 59 & 39.6 & 0.1524 & Flowing & Flowing & Unaffected. \\
\hline 60 & 30.2 & 0.1524 & 10.0 & & Muddiness cleared with pumping. \\
\hline 61 & 34.1 & 0.1524 & 4.6 & & Muddy for 2 days. \\
\hline 62 & 41.8 & 0.1524 & 39.9 & & Quite muddy for several days. \\
\hline 63 & 23.5 & 0.1524 & Flowing & & $\begin{array}{l}\text { Reported to have been polluted by } \\
\text { quake. Damaged casing (?). }\end{array}$ \\
\hline 64 & 9.4 & & 8.5 & & Unaffected. \\
\hline 65 & 34.7 & 0.1524 & 18.1 & 19.9 & May have dropped $1.5 \mathrm{~m}$ or more. \\
\hline 66 & 45.4 & 0.1524 & 6.0 & 7.2 & Dropped at least $0.9 \mathrm{~m}$ \\
\hline 67 & 36.6 & 0.1524 & Flowing & $7.1 \pm$ & Flow lost and had to install pump. \\
\hline 68 & 16.2 & 0.1524 & 4.3 & & Muddy for about 1 week. \\
\hline 69 & 42.7 & 0.1524 & & $24.4 \pm$ & $\begin{array}{l}6.1 \mathrm{~m} \text { of mud in casing. Pumped at } \\
3.8 \mathrm{~L} / \mathrm{sec} \text { for } 30 \text { hour to clear. }\end{array}$ \\
\hline 70 & 26.8 & 0.1524 & 6.4 & & Water level fel1 (pump damaged). \\
\hline 71 & 32.0 & 0.1524 & $25.9(?)$ & & Unaffected. \\
\hline 72 & 27.1 & 0.1524 & 7.9 & & Unaffected. \\
\hline 73 & 42.4 & 0.1524 & 21.4 & 26.0 & $\begin{array}{l}\text { Water leve } 1 \text { fell at least } 3.0 \mathrm{~m} \\
\text { and perhaps } 6.1 \mathrm{~m} .\end{array}$ \\
\hline 74 & 11.0 & 0.1524 & 4.6 & 2.0 & Muddy for unknown length of time. \\
\hline 75 & 53.6 & 0.1524 & & & Unaffected. \\
\hline 76 & 32.9 & 0.1524 & 2.1 & & Unaffected. \\
\hline 77 & 10.0 & 0.1524 & 3.0 & & $\begin{array}{l}\text { Had to redrill; now has "artesian" } \\
\text { at } 13.7 \mathrm{~m} \text {. }\end{array}$ \\
\hline 78 & 14.6 & 0.1524 & 1.4 & & Unaffected. \\
\hline 79 & 15.5 & 0.1524 & 4.1 & 8.2 & Minimum drop about $4.3 \mathrm{~m}$. \\
\hline 80 & 30.5 & 0.1524 & 10.7 & & Unaffected. \\
\hline 81 & 54.2 & 0.1524 & 6.1 & & Unaffected. \\
\hline 82 & 14.6 & 0.1524 & 5.5 & & Muddy for 5 days. \\
\hline 83 & 64.3 & 0.2032 & 17.1 & 18.2 & Possible drop of $1.2 \mathrm{~m}$ or more. \\
\hline 84 & 151.5 & 0.2032 & 13.2 & 19.1 & $\begin{array}{l}\text { Presumablv fell minimum of } 5.8 \mathrm{~m} \text {; } \\
\text { casing severely damaged. In the } \\
\text { Turnagain Heights area. }\end{array}$ \\
\hline 85 & 31.1 & 0.1524 & 18.3 & & $\begin{array}{l}\text { Water level fell and casing destroyed } \\
\text { near Turnagain Heights. }\end{array}$ \\
\hline
\end{tabular}




\begin{tabular}{|c|c|c|c|c|c|}
\hline No. & $\begin{array}{l}\text { Depth, } \\
\text { meters }\end{array}$ & $\begin{array}{l}\text { Diometer, } \\
\text { meters }\end{array}$ & $\begin{array}{l}\text { Water Level } \\
\text { (below land } \\
\text { Before }\end{array}$ & $\begin{array}{l}\text { meters } \\
\frac{\text { surface }}{\text { After }}\end{array}$ & Earthquake Effects \\
\hline 86 & 24.1 & 0.1524 & 19.2 & 19.7 & Probably unaffected. \\
\hline 87 & 31.7 & 0.1524 & Flowing & Flowing & Unaffected. \\
\hline 88 & 16.4 & 0.1524 & 4.9 & & Very muddy for 3 days; reported odor. \\
\hline 89 & 24.7 & 0.1524 & 6.1 & . & $\begin{array}{l}\text { Muddy for many weeks; water leve } 1 \\
\text { may have dropped. }\end{array}$ \\
\hline 90 & 4.9 & 4.9 & 2.4 & 2.3 & $\begin{array}{l}\text { Water level rose slightly; normal } \\
\text { in one day. }\end{array}$ \\
\hline 91 & 70.7 & 0.1524 & 15.2 & & Unaffected. \\
\hline 92 & 123.7 & 0.2032 & 16.3 & 17.4 & $\begin{array}{l}\text { Probably dropped at least } 0.91 \mathrm{~m} \text {, } \\
\text { possibly more. }\end{array}$ \\
\hline 93 & 92.9 & 0.1524 & 15.2 & & Unaffected. \\
\hline 94 & 112.8 & 4.9 & 18.6 & 21.3 & $\begin{array}{l}\text { Unaffected (?). Heavily pumped, } \\
\text { water level down } 2.7 \mathrm{~m} \text {. }\end{array}$ \\
\hline 95 & 97.2 & 0.1524 & 17.0 & & Unaffected. \\
\hline 96 & 71.0 & 0.1524 & 18.3 & & Muddy for 1 day. \\
\hline 97 & 84.7 & 0.2032 & 12.2 & & Muddy for 1 day. \\
\hline 98 & 35.7 & 0.1016 & 3.0 & 3.8 & Water level dropped about $0.91 \mathrm{~m}$. \\
\hline 99 & 70.4 & 0.1524 & 2.4 & 8.3 & $\begin{array}{l}\text { Water level reported to have dropped } \\
12.2 \mathrm{~m} \text {. }\end{array}$ \\
\hline 100 & 164.6 & 0.254 & 47.2 & 50.3 & Water leve 1 dropped about $3.0 \mathrm{~m}$. \\
\hline Valdez & 7.3 & & & & $\begin{array}{l}\text { Bent seaward by land movement; casing } \\
\text { sheared } 4.7 \text { m below tne surrace. }\end{array}$ \\
\hline Valdez & & & & & $\begin{array}{l}\text { Damaged, possibly by electric } \\
\text { failure. }\end{array}$ \\
\hline Valdez & & & & & Unaffected. \\
\hline Seward 4 & $\sim 30.5$ & & & & $\begin{array}{l}\text { Damaged; casing bent by earth } \\
\text { movement. }\end{array}$ \\
\hline Seward 5 & 230.5 & & & & $\begin{array}{l}\text { Damaged; casing bent by movement } \\
\text { of part of alluvial fan. }\end{array}$ \\
\hline Seward 6 & $\sim 30.5$ & & & & $\begin{array}{l}\text { Survived quake; about } 1 \text { month later } \\
\text { pump turbine } j \text { ammed because of } \\
\text { ground movement or settlement. }\end{array}$ \\
\hline
\end{tabular}




\section{REFERENCES}

1. C. M. Duke and D. J. Leeds. "Effects of Earthquakes on Tunnels." Protective Construction in a Nuclear Age, Proc. 2nd Protective Construction Symposium.

J. J. O'Sullivan, Rand Corporation (March 1959).

2. A. Rozen. Response of Rock Tunnels in Earthquake Shaking. M.S. Thesis, Massachusetts Institute of Technology, Cambridge, MA (1976).

3. C. H. Dowding. "Seismic Stability of Underground Openings." Proceedings First International Symposium Storage in Excavated Rock Caverns, Rockstore 77. Stockholm, Sweden, Pergamon Press, Vol. 2, pp. 231-38 (1978).

4. T. A. Jagger. "The Yokohama-Tokyo Earthquake of September 1, 1923." BuZZ. Seism. Soc. Am. 13(4), 124 (1923).

5. H. Kawasumi. General Report on the Niigata Earthquake of 1964. Tokyo Electrical Engineering College Press, Tokyo, Japan (1964).

6. National Research Council. The Great Alaskan Earthquake of 1964, Engineering Committee of the Alaskan Earthquake or the Division of Earth Sciences, Washington, DC. "The Alaskan Railroad," pp. 958-186; "Damage to Utilities," pp. 1034-1073.

7. B. Bolt, et al. Geological Hazards. Springer-Verlag, New York (1975), $328 \mathrm{pp}$.

8. K. V. Steinbrugge and D. F. Moran. "An Engineering Study of the Southern California Earthquake of July 21, 1952, and Its Aftershocks." BuZZ. Seism. Soc. Am. 44, 201 (1954).

9. W. R. Perret. "Close-in Ground Motion from the MILROW and CANNIKIN Events." BuZZ. Seism. Soc. Am. 62(6), 1459 (1972).

10. H. F. Cooper, Jr. Empirical Studies of Ground Shock and Strong Motions in Rock. Report RDA-TR-3601-002, R\&D Associates, Santa Monica, CA (October 1973).

11. H. C. Rodean. "Explosion-Produced Ground Motion: Technical Summary with Respect to Seismic Hazards." Symposium on Engineering with Nuclear Explosives. USAEC Report CONF-700101 (Vol. 2) (1970), pp. 1024-1050.

12. C. F. Richter. Elementary Seismology. W. H. Freeman and Company, San Francisco, CA (1958), pp. 578-582.

13. B. Gutenberg and C. F. Richter. "Earthquake Magnitude, Intensity, Energy, and Acceleration." Buzz. Seism. Soc. Am. 32, 163 (1942). 
14. F. Neumann. Earthquake Intensity and Related Ground Motion. University of Washington Press, Seattle, WA (1954).

15. C. F. Richter. "Earthquakes." Natural History 78, 36 (December 1969).

16. F. Press. "Earthquake Prediction." Scientific American 232 (5), 15 (1975).

17. S. T. Algermissen. "Seismic Risk Studies in the United States." Fourth World Conference Earthquake Engineering, Chile (1969).

18. J. L. Coffman and C. A. Von Hake (Editors). Earthquake History of the United States: National Oceanic and Atmospheric Administration. Revised Edition (through 1970), Publication 41-1. Nat. Oceanic and Atmos. Admin. U.S. Govermment Printing Office, Washington, DC (1977), 208 pp.

19. Nuclear Regulatory Commission. Procedures for Evaluation of Vibratory Ground Motions of Soil Deposits at Nuclear Power Plant Sites. Report NUREG-75/072, Shannon and Wilson, Inc., Seattle, WA; agbabian Associates, E1 Segundo, CA (1975), $197 \mathrm{pp}$.

20. N. N. Ambraseys. "Dynamics and Response of Foundation Materials in Epicentral Regions of Strong Earthquakes." Proc. 5th World Conference Earthquake Eng., Rome (1973).

21. R. K. McGuire. Seismic Stmuctural Response Risk Analysis, Incorporating Peak Response Regression on Earthquake Magnitude and Distance. Ph.D. Thesis, Massachusetts Institute of Technology, Cambridge, MA (1974).

22. H. B. Seed et al. Relationships Between Maximum Acceleration, Maximum Velocity, Distance from Source and Local Site Conditions for Moderately Strong Earthquakes. Report EERC-75-7, University of California (1975).

23. K. Kanai. "Improved Empirical Formula for Characteristics of Strong Earthquake Motions." Proc. Japan Earthquake Symposium. (1966).

24. G. K. Gilbert, R. L. Humphrey, J. S. Sewe11, and F. Soule. "The San Francisco Earthquake and Fire of April 18, 1906, and Their Effects on Structures and Structural Materials." BuZZ. 324, U.S. Geol. Survey, pp. 170, 54 pl. (1907).

25. State Earthquake Investigation Commission. The California Earthquake of Apriz 18, 1906. Carnegie Institute of Washington, Publ. 87 (1908).

26. J. P. Buwalda and P. St. Amand. "Geological Effects of the Arvin-Tehachapi Earthquake." Parts I-V, Califormia Division Mines BulZ. 171, 41 (1955). 
27. D. H. Kupfer, S. Muessig, G. L. Smith, and G. N. White. "Arvin-Tehachapi Earthquake Damage Along the Southern Pacific Railroad Near Bealville, California." Part I, Paper No. 7, Califomia Division Mines Bull. 171, 67 (1955).

28. Southern Pacific Company. "Earthquake Damage to Railroads in Tehachapi Pass." Part III, Paper No. 6, Califormia Division Mines Bull. 171, 241-248 (1955).

29. F. B. Blanchard and G. L. Laverty. "Displacements in the Claremont Water Tunnel at the Intersection with the Hayward Fault." Bulz. Seism. Soc. Am. 56, 291 (1966).

30. Y. Nishimatsu (Faculty of Engineering, University of Tokyo, Tokyo, Japan). Letter to Prof. W. F. Brace (Department of Earth and Planetary Sciences, Massachusetts Institute of Technology, Cambridge, MA) (September 2, 1977).

31. N. Nasu. "Comparative Studies of Earthquake Motion Above Ground and in a Tunnel." Part I, BulZ. Earthq. Res. Inst. 9, 454 (1931).

32. N. Nasu, F. Kishinouye, and T. Kodaira. "Recent Seismic Activities in the Idu Peninsula." Part I, BulZ. Earthq. Res. Inst. 9, 22 (1931).

33. K. Kanai and T. Tanaka. "Observations of the Earthquake Motion at the Different Depths of the Earth." Part I, BuZZ. Earthq. Res. Inst. 29, p. 107 (1951).

34. K. Kanai, K. Osada, and S. Yoshizawa. "Observational Study of Earthquake Motion in the Depth of the Ground. IV (Relation Between the Amplitude at Ground Surface and the Period)." BuZ2. Earthq. Res. Inst. 31, 228 (1953).

35. S. Okamoto. Introduction to Earthquake Engineering. University of Tokyo Press or John Wiley \& Sons, New York (1973).

36. D. S. Carder. "Seismic Investigations on the 500-Foot Leve1, Homestake Mine, Lead, South Dakota." Earthquake Notes 21, 13 (1950).

37. B. T. Brady. "Theory of Earthquakes, IV, General Implications for Earthquake Predictions." Pure Appl. Geophys. 114, 1031 (1976).

38. A. McGarr. U. S. Geological Survey, Menlo Park, CA 94025 (Private communication, 1977).

39. E. B. Ecke1. The March 1964 Alaska Earthquake - Lessons and Conctusions. U.S.G.S. Professional Paper 546, U.S. Government Printing Office, Washington, DC (1970).

40. P. R. Stevens. A Review of the Effects of Earthquakes on Underground Mines. Open-File Report 77-313, U.S. Geological Survey, National Center, Reston, VA (1977) 43 pp. 
41. J. B. Cooke. Peru Earthquake of 31 May 1970, Effect on Tunnezs. Supplementary Notes to EERI Report, Appendix IV. Earthquake Engineering Institute (September 1970).

42. S. Mueller, Professor of Geophysics, ETH, Zurich, Switzerland (Private Communication, 1977).

43. K. Mogi, Japanese Earthquake Institute (Private Communication, 1977).

44. K. Aki, Massachusetts Institute of Technology (Private Communication, 1977).

45. T. Iwasaki, S. Wakabayashi, and F. Tatsuoka. "Characteristics of Underground Seismic Motions at Four Sites Around Tokyo Bay." Wind and Seismic Effects, Proceedings of the Eighth Joint Panel Conference of the U.S.-Japan Cooperative Program in Natural Resources, NBS Special Bulletin 477, (1977), pp. III-41-III-56.

46. R. M. Waller. Effects of the March 1964 Alaska Earthquake on the Hydrology of the Anchorage Area. U.S.G.S. Professional Paper 544B, U.S. Government Printing office, Washington, DC (1966).

47. R. M. Waller. Effects of the March 1964 Alaska Earthquake on the Hydrology of South-Central Alaska. U.S.G.S. Professional Paper 544A, U.S. Government Printing Office, Washington, DC (1966) .

48. P. C. Heigold. Notes on the Earthquake of November 9, 1968, in Southern IZZinois. Illinois State Geological Survey Environmental Geology Notes, Number 24, Urbana, IL (1968).

49. Department of Interior - Department of Commerce, "The San Fernando, California, Earthquake of February 9, 1971." U.S.G.S. Professional Paper 733, U.S. Government Printing Office, Washington, DC (1971).

50. H. S. Lew, E. V. Leyendecker, and R. D. Dikkers. Engineering Aspects of the 1971 San Fermando Earthquake. U.S. Department of Commerce, National Bureau of Standards Building Science Series 40, U.S. Government Printing Office, Washington, DC (1971).

51. B. A. Bolt. "Earthquake Hazards." E®S, Trans. American Geophysical Union 59, 946 (1978).

52. C. Archambeau and C. Sammis. "Seismic Radiation from Explosions in Prestressed Media and the Measurement of Tectonic Stress in the Earth." Reviews of Geophysics and Space Physics 8, 473 (1970).

53. T. C. Bache and D. G. Lambert. The Seismological Evidence for the Triggering of Block Motion by Large Explosions. Systems, Science, and Software, La Jolla, CA (1976) 42 pp. 
54. J. A. Blume. "On the Prediction of Building Damage from Ground Motion." Symposium on Engineering with Nuclear Explosives, USAEC Report CONF-700101 (Vo1. 2), (1970) pp. 1103-1109.

55. H. F. Cooper. "A Review of Ground Shock Environments Pertinent to Deep-Underground Systems." Strategic Stmuctures Review Meeting at Stanford Research Institute, Menlo Park, CA (February 1977).

56. H. A. Nichol1s. A Case Study of the Validity of Scaling Laws for Report Explosion-Generated Motion." U.S. Bureau of Mines, Report RI 6472 (1964).

57. R. D. Munson. Vibration Response and Evaluation of Oiz Shale Mine Openings to the Rio Blanco Event. USBM Report 10013, Denver Mining Research Center, Bureau of Mines, Denver, CO, p. 21 (1975).

58. P. C. Loux. "Seismic Motions from Project Rulison." Symposium on Engineering with Nuclear Explosives. USAEC Report CONF-700101 (Vol. 2), (1970) pp 1070-1082.

59. L. A. Lee and R. E. Skjei. "The Effects of the Rulison Event on Buildings and Other Surface Structures." Symposium on Engineering with Nuclear Explosives. USAEC Report CONF-700101 (Vol. 2) (1970), pp. 1083-1091.

60. F. W. Osterwald et al. "Instrumentation Studies of Earth Tremors Related to Geology and to Mining at the Somerset Coal Mine, Colorado." U.S. Geological Survey Professional Paper 762 (1972) 27 pp.

61. D. Burgess. "Deep Basing - The Mighty Epic Experiment." Defense Nuclear Agency Strategic Division Biennial Review Conference (February 1977). 
F. R. Standerfer

U. S. Department of Energy

Richland Operations Office

P. O. Box 550

Richland, WA 99352

D. E. Large

U. S. Department of Energy

Oak Ridge Operations Office

P. 0. Box E

Oak Ridge, TN 37830

J. M. Batch (30 copies)

Battelle

Project Management Division

Office of Nuclear Waste Installation

505 King Avenue

Columbus, $\mathrm{OH} 43201$

J. 0. Neff

U. S. Department of Energy

Richland-Columbus

Battelle

505 King Avenue

Columbus, $\mathrm{OH} 43201$

F. Gera

OECD/Nuclear Energy Agency

38 Boulevard Suchet

F15016

Paris, France
R. M. Nelson

U. S. Department of Energy

Nevada Operations Office

P. 0. Box 14100

Las Vegas, NV 89114

D. Schueler

U. S. Department of Energy

Albuquerque Operations Office

P. 0. Box 5400

Albuquerque, NM 87115

C. R. Cooley

C. H. George

C. A. Heath

R. Stein

D. L. Vieth

Department of Energy

Division of Waste Management,

Production, and Reprocessing

Washington, DC 20545

H. R. Platt (20 copies)

Terra Tek, Univ. Research Park 420 Wakara Way

Salt Lake City, UT 84108 
T. F. Lomenick

W. C. McClain (3 copies)

Union Carbide Corporation

Nuclear Division

Oak Ridge, TN 37830

N. R. Tilford

Ebasco Services, Inc.

2211 W. Meadowview

Greensboro, NC 27407

D. Richards

J. R. Swaisgood

Dames \& Moore

605 Parfet St.

Denver, CO 80215

A. J. Eggenberger

D'Appolonia Consulting Engineers, Inc.

10 Duff Road

Pittsburgh, PA 15235

W. G. Smith

Dames \& Moore

455 E. Paces Ferry Rd.

At lanta, GA 30305

J. S. Ritchie

Kaiser Engineers

Kaiser Center

300 Lakeside Drive

Oakland, CA 94604

D. W. Lamb

Acres American, Inc.

Liberty Bank Bldg.

Main at Court St.

Buffalo, NY 14202

S. L. Crouch

C. Fairhurst

T. C. Atchison

Civil \& Mineral Engineering Dept. University of Minnesota

Minneapolis, MN 55455

Otto Brontzen

Geological Survey of Sweden

Svenska Geologiska Undersokning

Frescati S-104-105

Stockholm, Sweden
Earl Titcomb

Savannah District

U. S. Corps of Engineers

P. 0. Box 889

Savannah, GA 31402

Bruce A. Bolt

Seismographic Station

University of California

Berkeley, CA 94720

A. C. Tarr

W. W. Dudley, Jr.

Robin McGuire

W. S. Twenhofe1

John D. Bredehoeft

Robert M. Hamilton

U. S. Geological Survey

Denver Federal Center

Denver, CO 80225

John Briedis

Stone and Webster Engr. Co.

P. 0. Box 2325

Boston, MA 02107

G. A. Young

Agbabian Associates

250 North Nash Street

E1 Segundo, CA 90245

L. W. Lough

State Geologist

Louisiana Geological Survey

University Station, Box G

Baton Rouge, LA 70803

D. T. McMillan

State Geologist

Utah Geological and Mineral Survey

103 Utah Geological Survey Bldg.

University of Utah

Salt Lake City, UT 84112

W. H. Moore

State Geologist

Mississippi Geological, Economic, and Topographical Survey

P.O. Box 4915

Jackson, MI 39216 
R. A. Deju

D. A. Turner

R. E. Smith

Rockwell International

Atomics International Division

Rockwell Hanford Operations

P.0. Box 800

Richland, WA 99352

L. W. Scully

R. W. Lynch

R. Lincoln

Leslie R. Hill

W. D. Weart

Sandia Laboratories

P.0. Box 5800

Albuquerque, NM 87115

C. S. Groat

W. L. Fisher, Director

Texas Bureau of Economic Geology University Station, Box X

Austin, TX 78712

P. Stevens

G. D. DeBuchananne

U. S. Geological Survey

12201 Sunrise Valley Drive

Reston, VA 22092

J. Gale

University of Waterloo

286 Lincoln Road

Waterloo, N2J2P5

Ontario, Canada
Stephen G. Conrad

State Geologist

Department of Natural and

Economic Resources

P.0. Box 27687

Raleigh, NC 27611

Pradeep Talwani

Geology Department

University of South Carolina

Columbia, SC 29208

B. T. Brady

U. S. Bureau of Mines

Building 20

Denver Federal Center

Denver, CO 80225

David A. Gray

Assistant Director

Special Services Division

Institute of Geophysical Sciences

Exhibition Road

London, W.W.7, England

William W. Hambleton

State Geological Survey of

Kansas

Raymond C. Moore Hall

1930 Avenue A, Campus West

Lawrence, KS 66044

J. E. Russel1

$\mathrm{J}$. Handin

Department of Geology

Texas A\&M University

College Station, TX 77843

W. F. Brace

Department of Earth and

Planetary Sciences

Massachusetts Inst. of Technology

Cambridge, MA 02139 
K1aus Kühn

Gesellschaft fûr Strahlen-und-

Umweltforschung m.b.H. Munchen

Institut fûr Tieflagerung

Wissenschaftliche Abteilung

3392 Claustha1-Zellerfeld

Berliner Str. 2

Federal Republic of Germany

Daniel N. Miller, Jr.

State Geologist

Geological Survey of Wyoming

P.0. Box 3008, University Station

Laramie, WY 82071

Lars B. Nilsson

KDB Project (Kärnbränslesäkerhet)

FACK 12040

Stockholm 5, Sweden

G. E. Pinde'r

Department of Geology

Princeton University

Princeton, NJ 08540

John Pomeroy Technical Secretary

National Academy of Sciences

Committee of Radioactive Waste

Management

National Research Council

2101 Constitution Avenue

Washington, DC 20418

J. K. Costain

Lynn Glover

Gilbert Bollinger

Department of Geology and Geophysics

Virginia Polytechnic Institute and State University

Blacksburg, VA 24061

H. Y. Tammemangi

N. J. Hawley (2 copies)

Technical Information Services

Whiteshe11 Nuclear Research Establishment

Atomic Energy of Canada, Limited

Pinawa, Manitoba, ROE 1 LO

Canada
J. F. Davis

New York State Geological Survey

New York State Education Bldg.

Albany, NY 12229

J. B. Kemp

N. A. Norman

Bechte1 Corporation

50 Beale Street

P.0. Box 3965

San Francisco, CA 94119

V. E. Livingston, Jr.

State Geologist, Dept. of Natural Resources

Geology and Earth Resources Division

Olympia, WA 98504

C. A. Ratte

State Geologist, Office of the Secretary

Agency of Environmental Conservation Montpe1ier, VT 05602

J. W. Rold

State Geologist, Colorado Geological Survey, Room 254

1845 Whernan Street

Denver, CO 80203

A. E. Slaughter

State Geologist, Michigan Dept. of Conservation

Geological Survey Division

Stevens T. Mason Building

Lansing, MI 48926

H. R. Collins

State Geologist, Ohio Division of Geological Survey

Fountain Square, Building 6

Columbus, OH 43225

R. A. Abramovitch

Department of Chemistry and Geology

Clemson University

Clemson, SC 29631 
R. K. Dodds

Foundation Sciences, Inc.

520 S.W. Sixth Ave.

Portland, OR 97204

Hans M. Ewoldsen

Woodward-Clyde Consultants

Three Embarcadero Center

Suite 700

San Francisco, CA 94111

Serge Gonzales

Department of Geology

University of Georgia

Athens, GA 30602

Kenneth S. Johnson

Department of Geology

University of Oklahoma

Norman, OK 73069

Truman Stauffer

Department of Geosciences

University of Missouri

Kansas City, MO 64110

L. T. Long

School of Geophysical Sciences

Georgia Institute of Technology

Atlanta, GA 30322

James H. Crawford

Department of Physics

University of North Carolina at Chapel Hill

Chape1 Hi11, NC 27514

Stanley N. Davis

Department of Hydrology and Water Resources

University of Arizona

Tucson, AZ 85712

Fred A. Donath

Sandia Laboratories

Division 5413

Fuel Cycle Risk Analysis

Albuquerque, NM 87115
John C. Frye, Executive Director

Geological Society of America, Inc.

3300 Penrose Place

Boulder, CO 80301

Earnest F. Gloyna

College of Engineering

University of Texas at Austin

Austin, TX 78712

Konrad B. Krauskopf

Department of Geology

Stanford University

Stanford, CA 94305

M. Steindler

Argonne National Laboratory

9700 South Cass Avenue

Argonne, IL 60439

A. Brandstetter

A. M. Platt

Battelle Pacific Northwest

Laboratories

P.0. Box 999

Richland, WA 99352

J. A. Apps

N. G. W. Cook

P. A. Witherspoon

University of California

Lawrence Berkeley Laboratory

East End of Hearst Avenue

Berkeley, CA 94720

H. C. Heard

L. D. Ramspott

University of California

Lawrence Livermore Laboratory

P.0. Box 808

Livermore, CA 94550

K. E. Apt

G. A. Cowan

University of California

Los Alamos Scientific Laboratory

P.0. Box 1663

Los Alamos, NM 87545 
Richard Goodman

Dept. of Civil Engineering

University of California

Berkeley, CA 94720

Norman Owen

URS/Blume \& Associates

130 Jessie St. (at New Montgomery)

San Francisco, CA 94105

J. D. Scott

Fugro, Inc.

3777 Long Beach Blvd.

Long Beach, CA 90807

N. K. 01 sen

State Geologist

Division of Geology

State Development Board

Harbison Forest Dr.

Columbia, SC 29210

K. Weaver, Director

Maryland Geological Survey

Merryman Hall

Johns Hopkins University

Baltimore, MD 21218

S. Pickering, Jr.

Director, Earth and Water Resources

Dept. of Natural Resources

19 Hunter St., S.W.

Atlanta, GA 30334

J. L. Calver

State Geologist

Div. of Mineral Resources

Dept. of Conservation and Economic Development

P.0. Box 3667

Charlottesville, VA 22903

G. H. Fogle

Law Engineering Testing Company 2749 Delk Road, S.E.

Marietta, GA 30067

Robert Pyke

Civil/Nuclear Co.

2430 Broadway

San Francisco, CA 94115
J. D. Martinez

Robert L. Thoms

Institute for Environmental Studies

Louisiana State University

Baton Rouge, LA 70803

M. I. Goldman

J. J. DiNunno

NUS Corporation

4 Research Place

Rockville, MD 20850

T. R. Kuese1

Parsons-Brinckerhoff Quade \& Douglas, Inc.

One Penn Plaza

250 West 34th Street

New York, NY 10001

Paul F. Gnirk

RE/SPEC Inc.

P.0. Box 725

Rapid City, SD 57701

D. M. Ross-Brown

C. Young

Science Applications, Inc.

202 W. Magnolia St.

Fort Collins, CO 80521

Ronald Hofmann

Science Applications, Inc.

2450 Washington Avenue

Suite 120

San Leandro, CA 94577

J. H. Jones

Stearns-Roger Engineering Co.

700 South Ash

P.O. Box 5888

Denver, CO 80217

R. B. Mathiesen

C. Barry Raleigh

Art McGarr

U. S. Geological Survey

345 Middlefield Road

Menlo Park, CA 94025 